JESUELEM SALVANI FERREIRA

O APAGAMENTO DO /d/ EM MORFEMA DE GERÚNDIO NO DIALETO DE SÃO JOSÉ DO RIO PRETO 
JESUELEM SALVANI FERREIRA

\section{O APAGAMENTO DO /d/ EM MORFEMA DE GERÚNDIO NO DIALETO DE SÃO JOSÉ DO RIO PRETO}

Dissertação apresentada ao Instituto de Biociências, Letras e Ciências Exatas da Universidade Estadual Paulista, campus de São José do Rio Preto, para obtenção do título de Mestre em Estudos Linguísticos. Área de concentração: Análise Linguística.

Orientadora: Profa. Dra. Luciani Ester Tenani Co-orientador: Prof. Dr. Sebastião Carlos Leite Gonçalves

São José do Rio Preto

2010 
Ferreira, Jesuelem Salvani.

$\mathrm{O}$ apagamento do /d/ em morfema de gerúndio no dialeto de São José do Rio Preto / Jesuelem Salvani Ferreira - São José do Rio Preto : [s.n.], 2010.

142 f. : il. ; $30 \mathrm{~cm}$.

Orientador: Luciani Ester Tenani

Co-orientador: Sebastião Carlos Leite Gonçalves

Dissertação (mestrado) - Universidade Estadual Paulista, Instituto de Biociências, Letras e Ciências Exatas

1. Fonética. 2. Língua portuguesa - Fonologia. 3. Língua portuguesa - Gerúndio. 4. Variação linguística. I. Tenani, Luciani Ester. II.

Gonçalves, Sebastião Carlos Leite. III. Universidade Estadual Paulista, Instituto de Biociências, Letras e Ciências Exatas. IV. Título.

CDU $-81^{\prime} 344$

Ficha catalográfica elaborada pela Biblioteca do IBILCE

Campus de São José do Rio Preto - UNESP 


\section{JESUELEM SALVANI FERREIRA}

$\mathrm{O}$ apagamento do /d/ em morfema de gerúndio no dialeto de São José do Rio Preto

Dissertação apresentada para obtenção do título de Mestre em Estudos Linguísticos, área de Análise Linguística junto ao Programa de Pós-Graduação em Estudos Linguísticos do Instituto de Biociências, Letras e Ciências Exatas da Universidade Estadual Paulista "Júlio de Mesquita Filho", Campus de São José do Rio Preto.

\section{BANCA EXAMINADORA}

Prof $^{a}$. Dr ${ }^{\mathrm{a}}$. Luciani Ester Tenani

Professor Assistente Doutor

UNESP - São José do Rio Preto

Orientador

Prof $^{a}$. Dra ${ }^{\mathrm{a}}$. Cláudia Regina Brescancini

Professor Doutor

PUCRS - Porto Alegre

Prof. Dr. Roberto Gomes Camacho

Professor Assistente Doutor

UNESP - São José do Rio Preto

São José do Rio Preto, 06 de agosto de 2010. 
A Jesuel, Iolanda, Dara e Isu, que tanto me dedicaram muito amor e me incentivaram a prosseguir os estudos para ampliar meus conhecimentos. 


\section{AGRADECIMENTOS}

À Deus e a seus intercessores, Senhor Bom Jesus dos Castores e Nossa Senhora Aparecida, por sempre iluminarem os meus passos e me darem serenidade.

À minha orientadora Profa. Dra. Luciani Ester Tenani, por sua inteligência e raciocínio rápido nas análises linguísticas ter me despertado o interesse na mágica análise dos sons, por ser uma pessoa e uma profissional exemplar, por ter me escolhido para estudar teorias e me ensinar a construir um pensamento científico, e, assim, juntas podermos desenvolver pesquisas em nível de estágio básico, iniciação científica e mestrado, de modo que, durante esses seis anos de orientação e convivência, ajudou-me a crescer não só profissionalmente, mas também como ser humano.

Ao Prof. Dr. Sebastião Carlos Leite Gonçalves, pela ajuda e contribuição como co-orientador no desenvolvimento deste trabalho, e, pela atenção dedicada a mim não só como co-orientanda, mas também como alguém que gosta de mim.

À Profa. Dra. Cláudia Regina Brescancini e ao Prof. Dr. Roberto Gomes Camacho, por aceitarem o convite de participar da banca de qualificação e de defesa desta dissertação e pelas atentas leituras e preciosas sugestões feitas no momento da qualificação; e, à Profa. Dra. Larissa Berti e ao Prof. Dr. José Sueli Magalhães, pela leitura deste trabalho no momento da defesa.

À Profa. Larissa Berti, pelos ensinamentos sobre análises em Fonética Acústica e manuseio do programa Praat e à Profa. Dra. Flaviane Fernandes-Svartman, pelas observações feitas em eventos científicos e pela boa-vontade em tirar minhas dúvidas relacionadas ao programa Praat.

À Alex-Sandra Bernardes da Silva, Jacyra Mota, Lorena Nascimento, Maria Margarete de Paiva Silva e ao Fernando José Amaral e Beethoven Alvarez, pela 
disponibilização de seus trabalhos sobre o apagamento do /d/ nas formas com /ndo/ enviados por e-mail.

A todos os informantes do banco de dados Iboruna e às informantes do experimento acústico Ana Carolina, Kelly Cristina e Priscila, por colaborarem com o desenvolvimento desta pesquisa.

À Fundação de Amparo à Pesquisa do Estado de São Paulo - FAPESP, pelo auxílio financeiro durante dois anos da realização deste trabalho.

Aos funcionários da Biblioteca da UNESP/IBILCE pelo pronto atendimento às minhas solicitações.

Aos funcionários da Saepe, em especial ao Alex, por me amparar com os aparelhos de multimídia durante a realização da qualificação e da defesa do mestrado.

A todos os meus colegas de pós-graduação, em especial, Ana Maria, Cássio, Cleiliane, Flávia, Glaucia, Lisângela, Lívia, Luana, Maísa, Marcos, Marília, Mircia, Priscila, Regina, Solange, Tatiana, Vanessa e Viviane, pelas ricas observações que fizeram sobre o meu trabalho durante as minhas apresentações em sala de aula nas disciplinas que cursamos juntos, pois muito contribuíram para o avanço desta pesquisa.

À Adriana, Ana Luísa, Aline, Conrado, Daniervelin, Geovana, Márcia, Mircia, Raquel, Tatiana e Michel, por me acompanharem aos eventos científicos e/ou por me hospedarem em suas casas durante os congressos, por proporcionarem uma ótima descontração, pela troca de conhecimentos e por conhecê-los um pouco mais do que colegas de mestrado.

À Aline, Janaína, Joana, Letícia, Marcela, Patrícia, Priscila e Talita, pelo carinho.

Aos colegas funcionários do restaurante Passatempo por me divertirem, durante o trabalho, após as aulas das disciplinas do mestrado, em especial, à Maria 
Amélia que tanto ajudou a mim e à Kical, nos momentos difíceis que passamos por ainda não termos auxílio financeiro de nenhuma instituição.

Às minhas amigas e "irmãs" por parte de orientadora, Márcia e Adriana, pelo imenso carinho e atenção dedicados a mim, desde o processo de seleção até a conclusão do mestrado, e, por serem muito especiais pra mim.

Aos amigos da moradia estudantil da UNESP, em especial os moradores e agregados do bloco 2C, Amanda, Bárbara, Caio, Gil, Jéssica, José, Kátia, Lana, Leandro, Leandro (Sal), Luciana, Muriella e Philipi, por torcerem, sempre incentivarem e confiarem no meu potencial como pesquisadora.

Às integrantes do quarteto fantástico, Cláudia, Keslye e Paula, por, durante os nossos cafés da tarde, compartilharmos nossas alegrias, desabafos e conquistas de mestrandas (Je e Cláu), de advogadas (Keka e Paulinha) ou simplesmente de amigas.

Às minhas amigas mais que especiais, Eliana (Lika), Kelly (Kel), Raquel (Kical) e Mariana (Mari), e ao Filipi, Peterson e Iuri pelo apoio incondicional em todos os momentos que enfrentei antes e durante a realização do mestrado. Em especial, agradeço à Kel, por me acolher em sua casa após a minha graduação e por me tratar como parte de sua família, pois, ao seu lado, aprendi muitas coisas boas, que levarei por aonde eu for.

Aos meus pais, às minhas irmãs, ao Roberto e a todos os meus familiares, por simplesmente, amar vocês, pelo apoio, pelo amor incondicional, pela paciência e compreensão de minha ausência e tensões, durante a execução desta dissertação.

E, por fim, a todos aqueles que, direta ou indiretamente, contribuíram para o desenvolvimento deste trabalho e para a minha formação.

Meus sinceros agradecimentos. Muito obrigada! 
FERREIRA, Jesuelem Salvani. O apagamento do /d/ em morfema de gerúndio no Português falado no interior paulista. 2010. 142 f. Dissertação (Mestrado em Estudos Linguísticos) - Instituto de Biociências, Letras e Ciências Exatas, Universidade Estadual Paulista, São José do Rio Preto.

\section{RESUMO}

Este trabalho descreve o comportamento das formas de gerúndio no Português falado no interior paulista. Em tais formas, é possível verificar o fenômeno de apagamento do /d/ do morfema de gerúndio /ndo/, que passa a ser realizado como [no] na língua falada. Esse fenômeno também foi pesquisado em outras variedades do português brasileiro e constatou-se que se trata de um fenômeno variável (MOLLICA, 1989; CRISTÓFARO SILVA, 1996; DALPIN \& MÉA, 2002; HONÓRIO, 2005; MARTINS, 2006). A descrição do fenômeno, neste trabalho, é embasada nas teorias Sociolinguística Variacionista (LABOV, 1972, 1994) e da Fonologia Lexical (KIPARSKY, 1982; LEE, 1995). O corpus desta pesquisa é formado por dados de fala espontânea extraídos do banco de dados Iboruna, que contém amostras do Português falado na região de São José do Rio Preto (SP). Compõem a amostra da pesquisa 76 entrevistas de narrativas de experiências (NE) de informantes de sexo feminino e masculino, de renda familiar de até 10 salários-mínimos, pertencentes às cinco faixas etárias ( 7 a 15 anos, 16 a 25 anos, 26 a 35 anos, 36 a 55 anos e mais de 55 anos) e a quatro níveis de escolaridade $\left(1^{\circ} \mathrm{EF}, 2^{\circ} \mathrm{EF}, \mathrm{EM}\right.$ e ES). Para a análise variacionista das ocorrências, consideramos, além das três variáveis sociais (faixa etária, escolaridade e sexo/gênero), três variáveis linguísticas (estrutura sintática, material interveniente entre o auxiliar e o verbo no gerúndio da perifrase e tipo de auxiliar em perífrases). Para este estudo, foi elaborado, também, um experimento acústico para investigação das características fonéticas do fenômeno em análise. A partir da inspeção acústica, descrevemos os parâmetros acústicos do segmento /d/ em contexto de gerúndio na variedade do Português da região rio-pretense e mostramos uma perda de qualidade acústica da consoante /d/ (alteração nos valores de closura, burst, transição formântica e duração relativa dessa consoante), o que possibilita, por vezes, a não percepção de tal segmento nas formas de gerúndio. $\mathrm{Na}$ análise sob a ótica da Fonologia Lexical (FL), mostramos que o processo de apagamento de /d/ atinge apenas os verbos com morfemas de gerúndio /ndo/ como em 'fala[ndo]'. Verificamos, ainda, que esse tipo de regra se sujeita aos princípios da FL Condição de Ciclo Estrito e de Preservação da Estrutura, caracterizando-se uma regra lexical. Por meio da análise variacionista, verificamos que, do total de 999 ocorrências de gerúndio analisadas da amostra, 72\% delas apresentaram apagamento do /d/, o que evidencia que os falantes produzem mais a forma não-padrão, 'fala[no]'. As variáveis selecionadas como relevantes para a aplicação do apagamento foram: sexo/gênero, escolaridade, faixa etária e contexto morfossintático. A análise variacionista revelou que a frequência da aplicação da regra é alta na variedade estudada, especialmente em estruturas perifrásticas, sendo recorrente na fala dos homens, dos menos escolarizados e dos mais jovens (de 7 a 35 anos). Esses resultados assinalam um quadro típico de forma inovadora e estigmatizada.

Palavras-chave: Gerúndio; Processo fonológico; Fonética; Variação; Português brasileiro. 
FERREIRA, Jesuelem Salvani. The Deletion of /d/ in the Gerund Morpheme of Portuguese Spoken in São Paulo State. 2010. 142 f. Thesis (Master's degree in Linguistic Studies) - Instituto de Biociências, Letras e Ciências Exatas, Universidade Estadual Paulista, São José do Rio Preto.

\section{ABSTRACT}

This work describes the behavior of the gerund forms in the Brazilian Portuguese variety spoken in the inland of São Paulo State. In these forms, the phenomenon of deletion of the /d/ which is part of the gerund morpheme /ndo/ - being pronounced as [no] in this variety -, can be found. This phenomenon was also investigated in other varieties of Brazilian Portuguese, which evince that it is a variable phenomenon (MOLLICA, 1989; CRISTOFARO SILVA, 1996; DALPIN \& MEA, 2002; HONÓRIO, 2005; MARTINS, 2006). In this work, the description of the phenomenon is made under the perspective of the Theory of Linguistic Variation and Change (LABOV, 1972, 1994) and Lexical Phonology (KIPARSKY, 1982; LEE, 1995). The corpus of this research consists of spontaneous speech data taken from the Iboruna database, which contains samples of Brazilian Portuguese spoken in São José do Rio Preto (SP). From this database, narratives of experience (NE) of 76 interviews were selected and analyzed. These narratives were made by informants of one of both genders: (i) male or (ii) female; with family income of up to 10 minimum-wages, belonging to one of the following age-bands: (i) 7 to 15 years, (ii) 16 to 25 years, (iii) 26 to 35 years, (iv) 36 to 55 years, or (v) more than 55 years; and one of the following levels of education: (i) first four years of elementary school; (ii) last four years of elementary school; (iii) high school level or (iv) academic education level. For the variationist analysis of the occurrences, we considered, beyond the three social variables (age, educational level and gender), three linguistic variables (morphosyntactic context, intervening material between the auxiliary and the main verb in the gerund periphrasis and the type of auxiliary verb in circumlocutions). For this study, an experiment to investigate the acoustic phonetic features of the phenomenon in question was also made. From the acoustic inspection, the acoustic parameters of the segment /d/ of gerund in riopretense variety were described and a loss of acoustic quality of the consonant /d/ (change in values of Closure, burst, transition formant and duration relative this consonant) was shown, allowing, at times, a non-perception of this segment in the forms of gerund. From the perspective of Lexical Phonology (LP), it was shown that the process of deletion of $/ d /$ reaches only the gerund morphemes of verbs /ndo/, as in 'fala[no]'. This type of rule is subject to the principles of LP Strict Cycle Condition and Structure Preservation, characterizing a lexical rule. By variationist analysis of 999 occurrences of gerund, it was found that $72 \%$ of them had the deletion of /d/, which shows that speakers produce more the non-standard form, as in 'fala[no]' ('speaking'). The variables which were selected as relevant to the application of the deletion were: gender, education, age and morphosyntactic context. The variationist analysis revealed that the frequency of application of the rule is high in this variety, especially in periphrastic structures, being recurrent in the speech of the youngest (from 7 to 35 years) and less educated men. These results indicate a typical frame of an innovative and stigmatized form.

Keywords: Gerund; Phonological phenomenon; Phonetics; Variation; Brazilian Portuguese. 


\section{LISTA DE FIGURAS}

Figura 1. Eventos principais na produção das consoantes oclusivas..................................... 35

Figura 2. Mapa do Brasil, Estado, Região Administrativa e Município de São José do Rio Preto.

Figura 3. Mapa da região administrativa de São José do Rio Preto e os municípios fronteiriços 53

Figura 4. Foto da cidade de São José do Rio Preto (SP): Av. Philadelpho Gouvea Neto e ViadutoJordão Reis. 


\section{LISTA DE QUADROS}

Quadro 1. Variáveis linguísticas estabelecidas para o experimento

Quadro 2. Comparação entre análise perceptual e análise acústica, por aplicação (1) ou não aplicação (0) do apagamento da consoante /d/: Contexto Periffrase

Quadro 3. Comparação entre análise perceptual e análise acústica, por aplicação (1) ou não aplicação (0) do apagamento da consoante /d/: Contexto Frase Foco

Quadro 4. Classificação dos itens lexicais 89 


\section{LISTA DE TABELAS}

Tabela 1. Estimativa populacional 2008 de São José do Rio Preto/SP

Tabela 2. Frequência e percentual de pessoas alfabetizadas, por região Macro, Micro e Município de São José do Rio Preto e por anos de escolarização.

Tabela 3. Parâmetros acústicos da oclusiva [d] do verbo morrendo realizado pela informante 3 na última repetição (3)

Tabela 4. Frequência de aplicação e não-aplicação do apagamento da consoante /d/ nas análises realizadas.

Tabela 5. Valores médios da Closura da oclusiva /d/ em contexto de gerúndio nas Perífrases (P), Orações Reduzidas de Gerúndio (ORG), Frases Foco (FF) em Milissegundos (ms).

Tabela 6. Valores médios do Burst da oclusiva /d/ em contexto de gerúndio nas Perífrases (P), Orações Reduzidas de Gerúndio (ORG), Frases Foco (FF) em Milissegundos (ms).

Tabela 7.Valores médios da Transição do Formante F2 da oclusiva /d/ em contexto de gerúndio nas Perífrases (P), Orações Reduzidas de Gerúndio (ORG), Frases Foco (FF) em Hertz (Hz).

Tabela 8. Valores da Duração Relativa em contexto de gerúndio nas Frase Foco (FF) e Frase Foco Reduzida (FFR) em Porcentagem (\%).

Tabela 9. Variável sintática e morfológica do verbo: número de ocorrências e porcentagem

Tabela 10. Variável sintática e conjugação verbal: número de ocorrências 88

Tabela 11. Resultados da redução de gerúndio 90

Tabela 12. Percentual de aplicação do apagamento de [d] em morfema de gerúndio em diferentes variedades do PB

Tabela 13. Aplicação (Apl./total), frequência percentual (\%) e peso relativo (PR) do apagamento do [d] em morfema de gerúndio: estrutura sintática

Tabela 14. Número de ocorrências e Frequência percentual (\%) do apagamento do [d] morfema de gerúndio: estrutura sintática X material interveniente entre V1 e V"ndo"....

Tabela 15. Número de ocorrências e Frequência percentual (\%) do apagamento do [d] morfema de gerúndio: estrutura sintática X tipo de V1 
Tabela 16. Número de aplicação (Apl./total), Frequência percentual (\%) e peso relativo $(\mathrm{PR})$ do apagamento do [d] em morfema de gerúndio: faixa etária

Tabela 17. Pesos relativos do apagamento do [d] em morfema de gerúndio do grupo de fatores Faixa etária - comparação de duas variedades do PB....

Tabela 18. Número de aplicaçãol (Apl/Total), Frequência percentual (\%) e peso relativo (PR) do apagamento do [d] em morfema de gerúndio: escolaridade

Tabela 19. Frequência percentuais do apagamento de [d] em morfema de gerúndio do grupo de fatores Escolaridade - comparação de três variedades do PB

Tabela 20. Número de Aplicação (Apl.Total), Frequência percentual (\%) e peso relativo (PR) do apagamento do [d] em morfema de gerúndio: sexo/gênero.

Tabela 21. Frequências percentuais do apagamento do [d] em morfema de gerúndio do grupo de fatores Sexo/gênero: comparação de três variedades do PB

Tabela 22. Cruzamento entre as variáveis Faixa etária e Sexo: resultado em total de aplicação (Apl./Total), frequência percentual (\%) e peso relativo (PR) do apagamento do [d] em morfema de gerúndio

Tabela 23. Número de Aplicação (Apl./Total), Frequência percentual (\%) e peso relativo (PR) do apagamento do [d] em morfema de gerúndio: escolaridade X sexo

Tabela 24. Frequência percentual (\%) e peso relativo (PR) do apagamento do [d] do morfema de gerúndio: faixa etária X escolaridade.

Tabela 25. Cruzamento das variáveis: Tipo de V1 X. gênero

Tabela 26. Cruzamento das variáveis: Tipo de V1 X idade.

Tabela 27. Cruzamento das variáveis: Tipo de V1 X escolaridade

Tabela 28. Cruzamento das variáveis: Material interveniente X gênero.

Tabela 29. Cruzamento das variáveis: Material interveniente $X$. idade

Tabela 30. Cruzamento das variáveis: Material interveniente X escolaridade

Tabela 31. Cruzamento das variáveis: Estrutura sintática X gênero 138

Tabela 32. Cruzamento das variáveis: Estrutura sintática $X$ idade.

Tabela 33. Cruzamento das variáveis: Estrutura sintática $X$. escolaridade

Tabela 34. Características sociais dos informantes de cada AC 


\section{LISTA DE GRÁFICOS}

Gráfico 1. Percentual das atividades econômicas desenvolvidas em São José do Rio Preto.

Gráfico 2. Comparação de número de habitantes por grupos de idade entre o ano de 2000 e o de 2009.

Gráfico 3. Percentual de aplicação e não-aplicação do apagamento do [d] em morfema de gerúndio

Gráfico 4. Peso relativo da redução do gerúndio a partir da variável Faixa etária

Gráfico 5. Cruzamento das variáveis faixa etária e sexo/gênero: aplicação do apagamento do [d] do morfema de gerúndio (em P.R.).

Gráfico 6. Cruzamento das variáveis Escolaridade e Sexo: aplicação do apagamento do [d] do morfema de gerúndio.

Gráfico 7. Cruzamento das variáveis Faixa etária e escolaridade: aplicação do apagamento do [d] do morfema de gerúndio (em P.R.).

Gráfico 8. Peso relativo do cruzamento das variáveis Estrutura sintática e Sexo/gênero .... 138

Gráfico 9. Peso relativo do cruzamento das variáveis Estrutura sintático e Faixa etária .... 139

Gráfico 10. Probabilidades do cruzamento das variáveis Estrutura sintática e escolaridade.

Gráfico 11. Número de ocorrências por informantes femininos

Gráfico 12. Número de ocorrências por informantes masculinos 


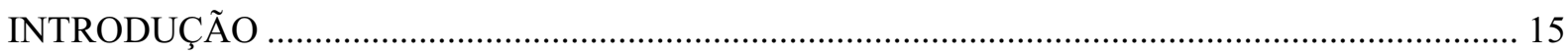

1 O FENÔMENO ABORDADO E FUNDAMENTAÇÃO TEÓRICA ….............................................20

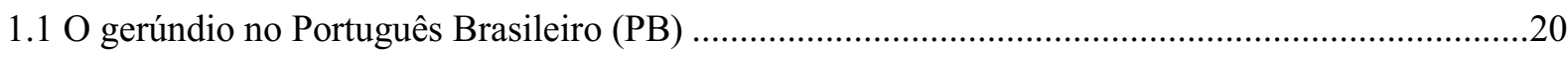

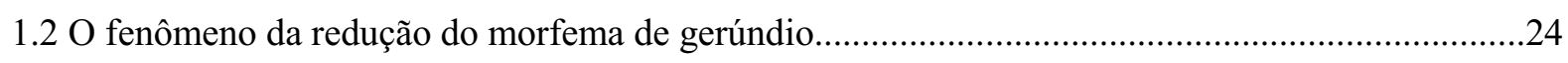

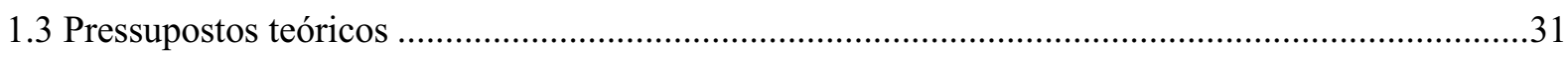

1.3.1 A Fonética Acústica: produção e percepção da fala.......................................................................31

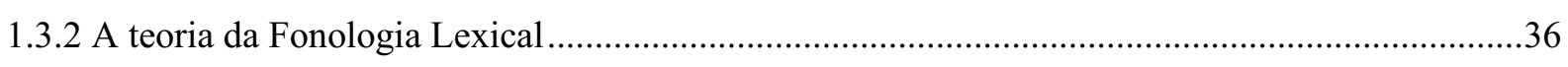

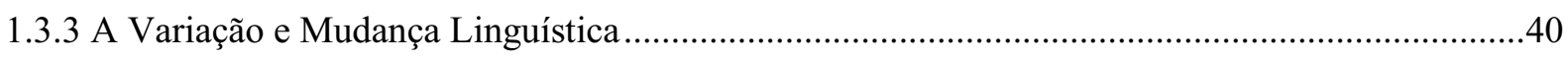

1.4 Resumo

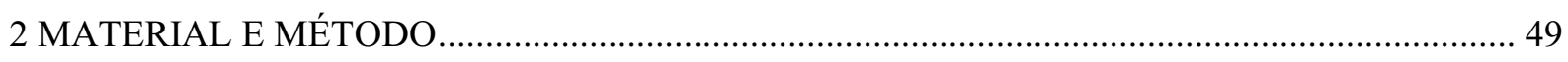

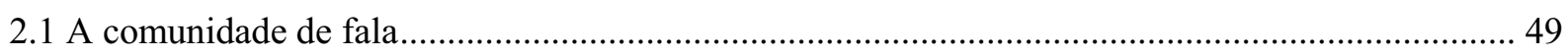

2.1.1 Breve história da região de São José do Rio Preto ................................................................... 50

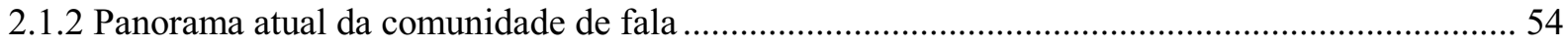

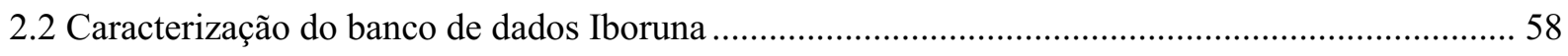

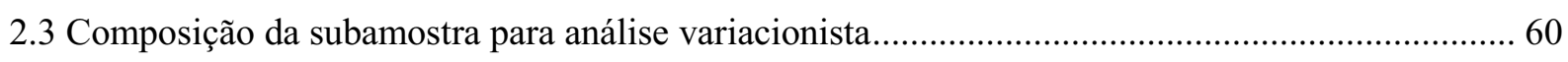

2.4 Elaboração de experimento para a inspeção acústica...................................................................... 64

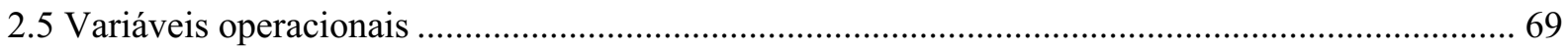

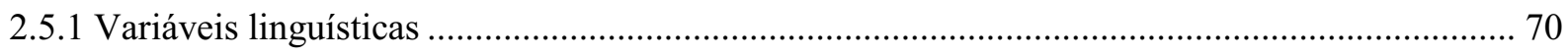

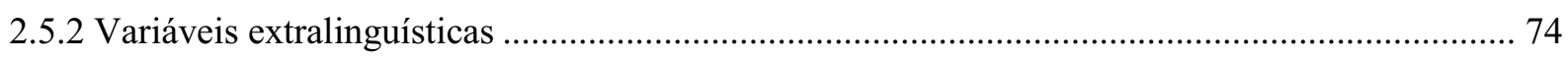

2.6 Passos metodológicos da quantificação e da análise variacionista .................................................. 76

2.7 Resumo

3 ANÁLISE DO APAGAMENTO DO [d] EM MORFEMA DE GERÚNDIO ................................ 78

3.1 Inspeção acústica do apagamento do [d] em morfema de gerúndio.............................................. 78

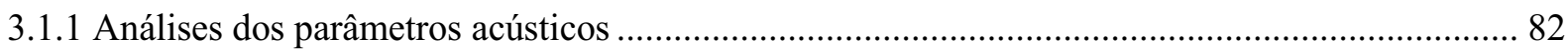

3.1.2 Discussões dos resultados obtidos e das hipóteses levantadas .................................................. 86

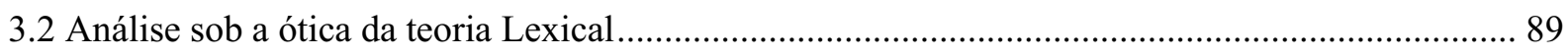

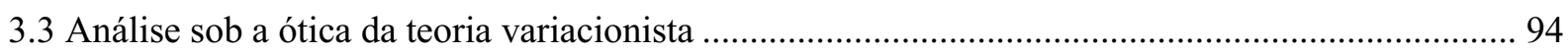




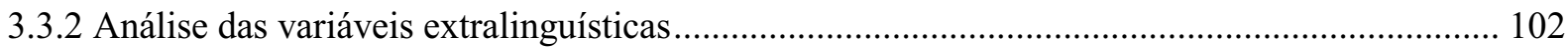

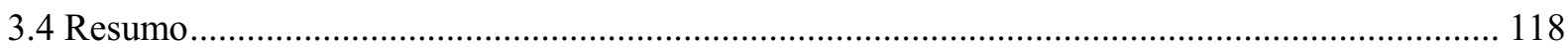

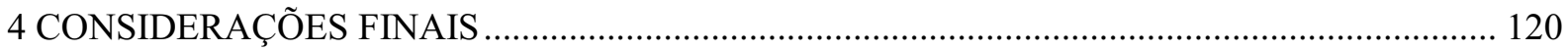

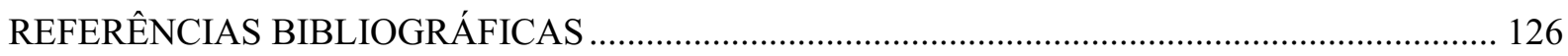

APÊNDICE A - Experimento para análise acústica .................................................................. 134

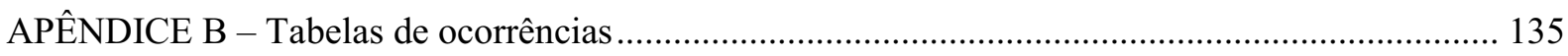

APÊNDICE C - Cruzamentos entre as variáveis linguísticas e as variáveis sociais .......................... 137

APÊNDICE D - Gráficos do comportamento dos informantes femininos e masculinos e Tabela de

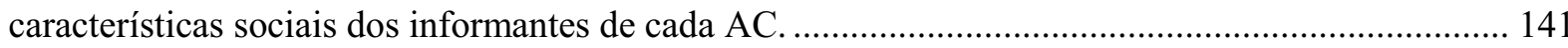




\section{INTRODUÇÃO}

O gerúndio, no Português Brasileiro (doravante, PB), é a forma verbal indicada pela junção do morfema flexional /ndo/, escrito "-ndo", à parte invariável do verbo, a raiz, como em falando. Sendo morfema a menor unidade dotada de significado, o morfema verbal é dotado de certa complexidade na aferição de seu significado, a qual decorre, em primeiro lugar, da cumulação das noções de modo e de tempo, além da noção suplementar de aspecto que às vezes se inclui nesta segunda noção. A forma de gerúndio é, morfologicamente, uma forma verbal, pois mesmo como determinante de um substantivo (para indicar um processo que nele se passa) não concorda com ele nem em número nem em gênero (cf. CAMARA JUNIOR, 1972).

Neste trabalho, analisamos o comportamento dos morfemas de gerúndio / Ndo/ que na fala podem ser realizados como [no], por meio de um processo fonológico de apagamento do /d/. Assim, formas como falando, comendo, pondo e partindo podem ser realizados, respectivamente, como 'fala[no]', 'come[no]', 'po[no]' e 'parti[no]', na variedade da região de São José do Rio Preto (SP). A escolha pelo estudo das formas de gerúndio justifica-se por esse fenômeno ser recorrente somente nos morfemas de gerúndio, como mostraremos a partir dos resultados de pesquisa da iniciação científica que fizemos (cf. FERREIRA, 2007).

No PB, são poucas as pesquisas sobre o comportamento fonológico de palavras em final /ndo/, como em Fernando, segundo, quando, e particularmente sobre a forma do verbo no gerúndio, como em amando, fazendo. A maioria dos trabalhos já realizados observa o gerúndio apenas a partir de uma perspectiva morfossintática (cf. LEMLE, 1984), e outros poucos observam sem aprofundamento do estatuto morfofonológico do fenômeno de redução do morfema de gerúndio. Encontramos referências esparsas sobre 
o gerúndio no interior de trabalhos de descrição mais geral do PB (cf. MOLLICA, 1989; CRISTÓFARO SILVA, 1996; HONÓRIO, 2005; MARTINS, 2006) e apenas um trabalho que se dedica exclusivamente à investigação do fenômeno de apagamento do /d/ em morfema de gerúndio sob perspectiva sociolinguística (cf. MARTINS, 2001), ou seja, não há muitos trabalhos que investiguem, por exemplo, como fatores sociolinguíticos atuam ou condicionam a aplicação variável do fenômeno que nesta dissertação é investigado. Neste estudo, investigaremos em que medida o fenômeno em análise é condicionado por fatores de natureza interna (linguísticos) e externa (extralinguísticos). Para além da escassez de investigação sobre o tema ora delimitado e da ausência de estudo sobre a variedade aqui investigada, a pesquisa sobre esse tema de uma perspectiva morfofonológica também se mostra pertinente, uma vez que esse processo de redução, na variedade do português de São José do Rio Preto (SP), se aplica somente a morfemas de gerúndio (cf. 'vende[ndo]' 'vende[no]') e nunca a formas que apresentam a mesma sequência fônica /ndo/, quer se tratem de formas verbais não gerundivas, como 've[ndo]', forma flexionada em primeira pessoa do verbo vender, ou de formas pertencentes a outras classes gramaticais, como 'Ferna[ndo]', 'segu[ndo]', 'qua[ndo]'. 1

No início desta pesquisa, que fizemos durante a iniciação científica, foram encontradas formas verbais que nunca têm a forma /ndo/ reduzido, como 've[ndo]' e 'ma[ndo]' (formas flexionadas em primeira pessoa singular dos verbos 'vender' e 'mandar', respectivamente) e outras formas em que /ndo/ pode ser reduzido a [no], como: 'fala[ndo]' $\sim$ 'fala[nu]' e 'vive[ndo]' $\sim$ 'vive[nu]'. Nessa pesquisa, constatou-se

\footnotetext{
${ }^{1}$ Como falante da variedade em estudo, ouvimos as realizações reduzidas "qua[no]”, "ta[me]m". No entanto, os possíveis informantes que produzem essas formas não fizeram parte dessa amostra, pois não encontramos realizações dessas formas reduzidas (em que $/ \mathrm{nd} />/ \mathrm{d} /$ e em que $/ \mathrm{mb} />/ \mathrm{m} /$ ). Assim, não é o foco desse trabalho analisar essas realizações.
} 
ainda que esse processo, denominado na literatura por redução ou assimilação da forma de gerúndio, se mostrou como forte característica na variedade do interior paulista. Tal processo também é descrito em outros trabalhos, mas não com a profundidade como a que aqui se propõe. Mollica (1989) descreve a redução do gerúndio para o dialeto carioca; Cristófaro Silva (1996) discute a interação entre o processo fonológico e os componentes fonológicos, morfológicos e sintáticos na gramática do português brasileiro; Martins (2001) descreve o apagamento da oclusiva dental na fala de João Pessoa (PB); Dalpian \& Méa (2002) abordam a transformação dos fonemas a partir das línguas populares do Brasil; Honório (2005) estuda a assimilação diante das consequências da oralidade relacionadas às convenções ortográficas da língua portuguesa; Oliveira e Marin (2005) elaboram um estudo acústico de base experimental da redução do gerúndio sob a perspectiva da teoria da Articulação Fonológica, e Martins (2006) descreve o processo fonológico para o dialeto mineiro.

De modo geral, na literatura, o processo fonológico de redução do gerúndio consiste no apagamento da consoante [d]. Segundo Cristófaro Silva (1996, p. 61), nesse processo, a consoante nasal cumpre o seu papel de nasalizar a vogal precedente e também passa a ocupar a posição de consoante inicial da sílaba final. No entanto, devido aos vários processos fonéticos-fonológicos que envolvem a redução do morfema de gerúndio, propomos considerar a assim chamada "redução do gerúndio" como um fenômeno de apagamento da consoante /d/ do morfema de gerúndio, visto que o [d] não é produzido na fala, como argumentaremos, por meio de uma inspeção acústica. ${ }^{2}$

Além disso, explicitaremos na subseção 3.2, uma questão de natureza fonológica, que diz respeito à nossa interpretação de a regra ser vista como de natureza

\footnotetext{
${ }^{2}$ A escolha por fazer uma inspeção e não uma análise acústica está justificada na subseção 3.1.
} 
lexical por se aplicar somente aos morfemas de gerúndio, embora se comporte como uma regra variável (o que por definição, é de natureza pós-lexical).

Em suma, o estudo das formas de gerúndio, como já deve ter ficado claro, é objeto deste trabalho e nossa meta geral é descrever e analisar o comportamento dessas formas verbais cujo morfema é /ndo/ e se altera para a forma [no], como, por exemplo, falando, que por meio do processo fonológico de apagamento da consoante /d/, pode ser realizado como 'fala[nu]', na variedade falada na região de São José do Rio Preto (SP). Nossa hipótese é que fatores sociolinguísticos condicionam o comportamento variável das formas $[$ ndo $] \sim[$ no] quando essas indicam gerúndio.

Para o desenvolvimento do tema aqui delimitado, este trabalho está organizado do seguinte modo: na seção 1, apresentamos os trabalhos que tratam da noção de gerúndio e a da redução do morfema de gerúndio, bem como os pressupostos teóricos que norteiam esta pesquisa, fazendo uma breve introdução à teoria da Fonética Acústica, a partir do conceito de produção e percepção da fala, em seguida, à teoria da Fonologia Lexical e seus princípios teóricos, e, por fim, à Teoria da Variação e Mudança Linguística, descrevendo os pressupostos teóricos que abordam a interação dos estudos da linguagem e dos estudos da sociedade.

$\mathrm{Na}$ seção 2, conceituamos comunidade de fala, apresentamos um breve histórico da região de São José do Rio Preto. Em seguida, descrevemos o banco de dados Iboruna e caracterizamos a composição da subamostra utilizada no presente trabalho. Por fim, apresentamos as etapas metodológicas e os fatores de análise que embasaram esta pesquisa.

$\mathrm{Na}$ seção 3, realizamos as discussões dos resultados do fenômeno de apagamento da consoante /d/ em morfema de gerúndio: a partir da análise dos resultados originados do experimento acústico, investigamos os contextos linguísticos 
mais relevantes para a aplicação do fenômeno; a partir das análises da regra de apagamento, sob a ótica da teoria da Fonologia Lexical, argumentamos a favor da interpretação da regra como sendo de natureza lexical e, sob a ótica da teoria Sociolinguística Variacionista, a partir dos resultados de aplicação da regra de apagamento na subamostra extraída do banco de dados Iboruna, demonstramos quais e como atuam na aplicação da regra analisada as variáveis linguísticas investigadas, tais como, Estrutura sintática, Tipo de V1 da perifrase e Material interveniente entre V1 e V'ndo'; e as variáveis sociais, tais como, Sexo/gênero, Idade e Escolaridade.

Na seção 4, apresentamos nossas considerações finais com base nos resultados obtidos e nas discussões realizadas nas seções anteriores.

Ao final desta dissertação, encontram-se, no apêndice, a ficha do experimento acústico que elaboramos, a lista das ocorrências identificadas, as tabelas dos cruzamentos entre as variáveis linguísticas e sociais e os gráficos com a quantidade de aplicação da regra para cada informante da amostra. 


\section{O FENÔMENO ABORDADO E FUNDAMENTAÇÃO TEÓRICA}

Na presente seção, são abordados os pressupostos teóricos que norteiam a investigação do tema desta dissertação. A apresentação está organizada da seguinte maneira: na subseção (1.1), tratamos sobre o gerúndio no português; em (1.2), retomamos alguns trabalhos que abordam o fenômeno estudado no PB; na subseção (1.3), abordamos as teorias que embasam nossas análises, tais como, a teoria da Fonética Acústica e o conceito de produção e percepção da fala, a teoria da Fonologia Lexical e seus princípios teóricos e a teoria da Variação e Mudança Linguística e seus pressupostos teóricos por meio dos quais analisamos as regras variáveis.

\subsection{O gerúndio no Português Brasileiro (PB)}

Câmara Jr. (1972, p. 92), em seu livro Estrutura da língua portuguesa, no capítulo dedicado à Significação geral das noções gramaticais do verbo, argumenta que, entre as formas nominais dos verbos, o gerúndio é morfologicamente uma forma verbal, pois, ao contrário das outras, não concorda com o substantivo nem em número nem em gênero. Segundo esse linguista, podemos inferir que a marca da vogal temática que caracteriza a conjugação verbal do gerúndio apresenta "uma vogal tônica /a/ para a primeira conjugação, /e/ para a segunda conjugação e /i/ para a terceira conjugação" (p. 98). Quanto aos sufixos flexionais dessa forma, o número-pessoal é marcado como zero 
(Ø), já o modo-temporal que segue a vogal temática é assinalado como / $\mathrm{Ndu} /$, escrito "ndo". 3

Coutinho (1967, p. 275), ao descrever algumas perdas sofridas pelo latim literário, argumenta que o gerúndio teve novo emprego, pois a forma no ablativo substituiu em parte o particípio presente. Por outro lado, não se passou ao português o emprego do gerundivo, que se encontra representado, em português, por alguns substantivos e adjetivos, como, por exemplo, merenda, oferenda, memorando, infando e nefando. Assim, segundo Coutinho, foi-se vulgarizando entre nós a terminação "-ndo" com valor de substantivo verbal numa série de palavras cultas: examinando, educando, graduando, professorando, doutorando.

Campos (1972), ao realizar um estudo histórico-descritivo do gerúndio no português em textos latinos, verificou que: (i) o latim clássico possuía três formas nitidamente distintas de gerúndio, que eram chamadas de gerúndio (forma do ablativo), de gerundivo (adjetivo verbal, da voz passiva, quando construído com regência verbal) e de particípio presente (forma adjetiva do verbo) ${ }^{4}$ (ii) a forma ablativa do gerúndio destaca-se por ser a única que permaneceu até hoje nas línguas românicas, tendo sido usada no latim clássico com valor adverbial instrumental, referindo-se diretamente ao verbo da oração principal.

Segundo a autora, pode-se observar, ainda, que, nas línguas românicas, há uma uniformidade quanto ao uso do gerúndio. Em todas elas, encontramos: (i) o gerúndio circunstancial largamente desenvolvido em relação ao latim, como, por exemplo, "e em

\footnotetext{
${ }^{3}$ Notação utilizada por Câmara Jr. (1970), no nosso trabalho, optamos pela notação /ndo/.

${ }^{4}$ Para exemplificar, o gerúndio seria um caso como em "Homines exercendo videmus conteri" Tradução: Vemos homens se consumirem trabalhando (p.9); o gerundivo, um caso como "cui rei, cui gloriae, cui uirtuti studere? Patrimonione augendo?" Tradução: a que feito, a que glória, a que virtude te dedicas? a aumentar o patrimônio?) (p.6) e o particípio presente, por exemplo, "id quidem agitans mecum sedulo; Inueni, opinor, remedium huic rei" Tradução: pensando comigo mesma, com cuidado, acho que encontrarei um remédio para esta situação(p.14). (Cf. CAMPOS, 1972).
} 
se tratando de pessoas jurídicas, não podem distribuir bonificações acionistas" (CAMPOS, 1972, p.37); (ii) o uso do gerúndio adjetivo indicando qualidades transitórias, comum em todas as línguas, com exceção do francês, no qual se usa o particípio presente. Como exemplo de gerúndio adjetivo, temos " $A$ verdade é que não as procurava, esperando talvez que acontecesse" (CAMPOS, 1972, p.45); (iii) o uso de perífrases para indicar certa matiz de aspecto, que não é expresso pela conjugação simples, como, por exemplo, "Fabiano estava se casando à toa" (CAMPOS, 1972, p.53). A autora afirma que essas perífrases existem em maior variedade em certas áreas, como na Península Ibérica, e são mais raras em outras, como no romeno e no francês.

Campos (1972) acrescenta ainda que, nos textos arcaicos analisados em sua pesquisa, os valores fundamentais do gerúndio são: o adverbial, o circunstancial, o adjetivo, o coordenado e as perífrases. Nos textos do português contemporâneo, surgem novos tipos de gerúndio, e os que já existiam se desenvolveram. Segundo a autora, as principais inovações foram (cf. exemplos em CAMPOS, 1972):

(i) uso do gerúndio narrativo (a), exclamativo (b) e interrogativo (c);

Ex.:

(a) A casa no escuro, os meninos em redor do fogo, a cachorra Baleia vigiando. (p. 158)

(b) Ô diacho! E a gente precisando tanto de cobre, hein, Marcolino. (p. 161)

(c) Leleco: Que é isso, Zé Gato? Dando pulo de costas por causa de uma violinha? (p. 162)

(ii) amplo emprego do gerúndio adjetivo;

Ex.: não demoraria a enxergar a lanterna vermelha do saveiro brilhando na noite do mar (p. 146) 
(iii) o gerúndio coordenado, que até então se limitou às orações aditivas

(a), estende-se às adversativas (b) e conclusivas (c);

Ex.:

(a) A velha correu logo para a Tia Maria, ajoelhando-se a seus pés...

(p. 154)

(b) Agora, posso afirmar que os dirigentes do serviço voltaram atrás, apresentando, porém, uma série de dificuldades. (p. 155)

(c) ...submetidos à Assembléia, receberam aprovação unânime, sendo, portanto, eleitos... (p. 156)

(iv) o gerúndio circunstancial encontra-se com certas partículas não registradas em outros textos, tais como embora, mesmo, só e nem;

Ex.: é um sujeito que, mesmo sendo obrigado a ajoelhar-se, mesmo reduzido aos pecados, continua sendo um homem digno... (p. 126)

(v) desenvolvem-se as perífrases formadas com estar, em detrimento das com ir, que passam a se colocar em segundo plano em ordem de freqüência; surgem também perífrases novas, tais como as formadas com sair, começar, terminar, continuar, viver entre outros.

Ex.: A cachorra Baleia saiu correndo entre os alastrados e quipás, farejando a novilha raposa. (p. 193)

Mais recentemente, quanto ao emprego do gerúndio, Cunha \& Cintra (2001, p. 490), de uma perspectiva da Gramática Tradicional por exemplo, descrevem que o gerúndio pode se apresentar de duas formas: uma simples (lendo) e outra composta (tendo ou havendo lido). Segundo os autores, a forma simples expressa uma ação em curso, que pode ser imediatamente anterior ou posterior ou ainda simultânea à ação expressa pelo verbo da oração principal. A forma composta é de caráter perfeito e indica uma ação concluída anteriormente à que exprime o verbo da oração principal. 
Cunha \& Cintra (2001) afirmam que as formas de gerúndio podem constituir tanto perífrases verbais quanto orações reduzidas de gerúndio. Essas orações reduzidas podem ser caracterizadas como adjetiva reduzida de gerúndio e adverbiais reduzida de gerúndio, sendo que a primeira tem valor adjetivo e a segunda, valor adverbial.

Do ponto de vista da gramaticalização, há algumas propostas sobre uma nova classificação das construções gerundivas e suas funções, que levam em consideração as especificidades sintáticas, semânticas e discursivas (cf. BRAGA \& CORIOLANO, 2007; SIMÕES, 2007), as quais serão discutidas brevemente quando descrevermos as variáveis linguísticas estudadas.

\section{$1.2 \mathrm{O}$ fenômeno da redução do morfema de gerúndio}

Feito um quadro sucinto do funcionamento do gerúndio em Português, passamos agora a tratar do fenômeno fonológico que afeta as formas do gerúndio. Antes de iniciarmos a descrição de alguns trabalhos que abordam o fenômeno da redução do morfema de gerúndio no Português Brasileiro (PB), fazemos uma discussão sobre o que sejam os processos de assimilação e de apagamento, os quais estão envolvidos na redução do morfema de gerúndio.

Amaral (1920) em $O$ dialeto caipira, já assinalava o processo de assimilação de /nd/ > /n/ como marca presente no dialeto caipira do PB.

Nascentes (1953, p. 67), citando Coimbra (1950, p. 32), afirma que, na assimilação de /também/ $\sim$ /tammém/ $\sim$ /tamém/, ocorre um retardamento do movimento do véu palatino, que não abaixa logo após a articulação do $/ \mathrm{m} /$, e isso faz com que seja nasalizado também o /b/; em seguida, simplifica-se o duplo $/ \mathrm{mm} /$. A 
descrição desse processo também pode servir de base para a descrição da assimilação de /ndo/ /nno/ nos morfemas de gerúndio.

Camara Jr. (1970), utilizando das palavras de Grammont (1933, p. 186), descreve a assimilação como "uma extensão de um ou vários movimentos articulatórios além do seu domínio originário”. Em outros termos, segundo Camara Jr., um fonema adquire traços articulatórios novos pela influência de outro contíguo, caracterizando-se, por essa contiguidade, a assimilação em face da dilação. As articulações dos dois fonemas se aproximam em assimilação parcial (ex.: /layte/, de lacte- > leite, tauru- > touro) ou se igualam em assimilação total (ex. saeta, de sagitta $>$ seeta, donde - seta). Os fonemas cujos traços articulatórios se propagam ao outro é o assimilador, ou fonema forte; esse outro é o assimilado, ou fonema fraco; conforme o assimilador precede ou segue o assimilado, diz-se que a assimilação é, respectivamente, progressiva (víbera, de vipera > víbora) ou regressiva (persicu- > pêssego).

Para o autor, na evolução da língua portuguesa, a assimilação desempenhou um papel importantíssimo, pelo fato de atuar em fenômenos de sonorização, vocalização, palatalização e ainda no fechamento do timbre da base de um ditongo decrescente assimilada pela semivogal (/aw/ > /ôw/, /ay/ > /êy/). (CAMARA JÚNIOR, 1970, p. 87).

Segundo Collinschonn (2006), há muitos exemplos de assimilação em português: vogais que se tornam nasalizadas porque estão seguidas de consoante nasal, fricativas que tornam-se vozeadas porque estão seguidas de consoante vozeada, consoantes que se palatalizam porque estão seguidas de vogais com característica 'palatal'. Quanto ao processo de apagamento, a autora afirma que também há muitos fenômenos de apagamento sistemático no português contemporâneo: /r/ no final de formas infinitivas dos verbos, /s/ em final de substantivos e verbos, monotongação (caso de [fera] por feira), entre outros. 
A redução de /ndo/ é, há muito tempo, abordada por alguns autores que descrevem as variedades do PB. Segundo os trabalhos de dialetologia, o fenômeno de assimilação do /d/ em morfema de gerúndio no PB é registrado desde o trabalho de Amaral (1920). Assim, encontram-se sobre o tema vários estudos dialetológicos como o de Marroquim (1934) e Teixeira (1938), variacionistas como o de Mollica (1989) e Martins (2001), fonético-fonológicos como de Dalpian e Méa (2002) e de Cristófaro Silva (1996), entre outros.

Marroquim (1934), ao pesquisar a variedade do nordeste, mais especificamente Alagoas e Pernambuco, verificou, nesses dialetos, o fenômeno de assimilação nos grupos /rl/, /mb/ e /nd/: 'Ca[r]ro' (Carlos), 'ta[m]ém' (também), 'corre[no]' (correndo). Segundo Marroquim (1934, p. 86), este fenômeno, antigamente, foi atribuído, por muitos alguns autores, à influência africana operada no grupo /nd/. Entretanto, a opinião do autor é diferente:

Não creio entretanto nisso. Os africanos teriam sentido dificuldade em pronunciar o grupo, e, por menor esforço, te-lo-iam modificado, como o simplificou pelo mesmo motivo o resto da população, sem que uns imitassem outros. No grupo dialetal aquilano-umbro-romano dá-se o mesmo fenômeno, outrória mais generalizado na Itália, sem suspeita de influência africana. (MARROQUIM, 1934).

Melo (1946) também trata da eventual redução do grupo /nd/ para /n/ como resultado da influência das línguas tupi ou africana, porém, ele compartilha da mesma visão de Marroquim, argumentando que esse fenômeno foi encontrado em outras línguas alheias à ação das línguas de contato.

Sirva de exemplo o latim vulgar. O osco e o úmbrio tinham $n n$ quando o latim dizia nd (...) O Appendix Probi (214) corrige grundio non grunnio. São atestados ainda agenna em vez de agendai (MELO, 1946, p. 57). 
Já Coutinho (1967, p.326) ratifica a tese da influência da língua africana e, em tom preconceituoso, assim se pronuncia:

essas formas profundamente alteradas, esse vocábulo comum e rústico, essa construção viciadíssima, que caracterizam o falar do nosso roceiro, estão a atestar, em grande parte, a sua procedência africana, indiana ou afro-indiana, como por exemplo, amô (amor); fio (filho); quano (quando); andano (andando); tamém (também).

Seguindo o mesmo ponto de vista de Marroquim (1934) e Melo (1946), Silva Neto (1952) salienta que as mudanças de $/ \mathrm{nd} / \mathrm{em} / \mathrm{nn} /, / \mathrm{mb} / \mathrm{em} / \mathrm{m} /, / \mathrm{ld} / \mathrm{em} / 11 / \mathrm{já}$ existem há muito tempo e que tais assimilações são passíveis de se verificar em qualquer espaço ou tempo, mas que, por singular coincidência, ocupam áreas homogêneas no norte da Península Ibérica e no sul da Itália. Assim, tal fato se explicaria pela influência do osco-úmbrio, substrato das áreas italianas e elemento demográfico significativo na colonização do norte da Hispânia.

Conforme propõem muitos estudiosos, a realização reduzida das formas de gerúndio quando ocorre 'ama[nu]' para amando é favorecida por o segmento nasal ter os mesmos traços de ponto de articulação da consoante /d/ adjacente, ou seja, /n/ e /d/ são [+ anterior $]$ e [+ coronal $]$.

Cristófaro Silva (1996) apresenta um estudo sobre alguns aspectos de mudanças na organização da sequência sonora do português de Belo Horizonte para investigar a interação entre processos fonológicos e os componentes morfológicos e sintáticos da gramática, levando em conta pressupostos teóricos propostos por Kaye (1988, 1995), Kaye \& Vergnaud (1990). Segundo a autora, em algumas variedades do português brasileiro ocorrem formas como: 'fala[nu]' e 'menti[nu]' (para falando e 
mentindo, respectivamente), em que a sequência de vogal nasal acentuada seguida de /d/ passa a /n/. Segundo palavras da autora:

Quando temos [falãdu] a consoante nasal cumpre o seu papel de nasalizar a vogal precedente e /do/ ocorre como a sílaba final. Quando temos [falãnu] a consoante nasal cumpre o seu papel de nasalizar a vogal precedente, mas a consoante nasal irá também ocupar a posição de consoante inicial da sílaba final. (CRISTÓFARO SILVA, 1996, p. $61)$.

Cristófaro Silva salienta ainda que: (i) o processo de redução se aplica apenas às formas de gerúndio; (ii) esse processo se aplica com informação morfológica dada pelo componente fonológico e morfológico (forma de gerúndio); (iii) o processo não levará à reorganização lexical, ou seja, não haverá mudança de organização interna do léxico, visto que palavras contendo o mesmo contexto favorável à redução e que não portam informação morfológica de gerúndio não são afetadas pelo processo. Antecipamos que essa caracterização também é semelhante a que fazemos para a variedade do noroeste paulista.

Dalpian e Méa (2002), ao tratar de questões fonético-fonológicas da língua portuguesa, por meio de uma perspectiva diacrônica e sincrônica, que considera tanto o passado latino como a realidade das linguagens populares do Brasil, dedicam uma seção do seu trabalho aos processos que consistem na troca ou transformação de fonemas. Os autores afirmam que, na redução do morfema de gerúndio, há um processo de assimilação na troca do /nd/ por /n/, como em: andando > 'anda[no]', falando > 'fala[no]', comendo $>$ 'come[no]', fazendo $>$ 'faze[no]', vendo $>$ 've[no]', cantando $>$ ‘canta[no]'. Para eles, o fato de os fonemas dentais ou alveolares, respectivamente, [n] e [d] serem pronunciados na mesma zona de articulação torna-os iguais ou semelhantes, quanto ao modo de articulação. Dessa maneira, a forma andando passaria por dois 
processos 'anda[nno]' > 'anda[no]': a primeira forma é uma assimilação em que o /d/ se transforma em $/ \mathrm{n} /(\mathrm{nd}>\mathrm{nn})$ e a segunda é uma simplificação $(\mathrm{nn}>\mathrm{n})$. Para esses estudiosos, “a assimilação é um dos processos de transformação fonética mais produtivo da língua portuguesa, tanto no passado quanto no presente" (p. 12). Portanto, a redução de gerúndio decorre de um fenômeno antigo do português, como já mencionado anteriormente.

Honório (2005), que estuda as consequências da oralidade relacionadas às convenções ortográficas, tece um rápido comentário em torno da transformação da forma do gerúndio com a terminação "-ndo" em [no], e a classifica também como assimilação, pois devido aos fonemas /d/ e /n/ pertencerem às consoantes dentais podem sofrer uma espécie de "confusão" na pronúncia, resultando na assimilação.

Martins (2006), ao fazer um trabalho sobre mudança linguística no dialeto mineiro, não deixa de mencionar que a redução de morfema de gerúndio, que, à primeira vista, poderia ser visto como uma lei do menor esforço na articulação do morfema, na verdade, é uma tendência observada no câmbio linguístico latinoportuguês, o qual possibilitou, segundo o autor, a mudança de contextos $/ \mathrm{nd} />/ \mathrm{nn} /$, como em verecundi > verecunni > vergonha. Então, tanto diacrônica quanto sincronicamente, o fenômeno se baseia na assimilação do [d] pela consoante nasal [n], ambas dentais ou alveolares.

Há também o trabalho de Oliveira \& Marin (2005), que aborda o fenômeno de apagamento da consoante /d/ a partir de um estudo acústico, de base experimental, embasado na Fonologia Articulatória. Para eles, esse fenômeno é um padrão de coordenação velar, isto é, o fenômeno se deve à reorganização gestual de uma instável coordenação padrão, em que a coda nasal se acopla à unidade oral, coordenando a uma nova posição na sílaba. Segundo os autores, ocorre uma reorganização das unidades 
mínimas no padrão de coordenação entre a unidade velar oral e a unidade em coda.

Cabe salientar que não constitui preocupações dos autores caracterizar morfossintática e morfofonologicamente o fenômeno, nem tão pouco os condicionamentos sociais.

Em nossa pesquisa, tomaremos o termo "apagamento" para designar o processo de eliminação do [d], isto é, a não realização do fonema /d/ no morfema de gerúndio /ndo/. Segundo Cagliari (2002), a regra de eliminação ocorre quando há a supressão de um segmento da forma básica de um morfema. Assim, a forma nominal do gerúndio do verbo falar, falando, tem a oclusiva [d] apagada no dialeto riopretense, como se observa em (1)

(1) /falando/ $\quad$ [falãndo $] \quad \rightarrow \quad$ [falãno $]$

Neste trabalho, argumentos para adotarmos a posição, segundo a qual

$$
/ \mathrm{d} / \rightarrow<\emptyset>/ \mathrm{v}+\left[\mathrm{n} \_\mathrm{o}\right]
$$

em que /d/ pode não ser realizado quando em contexto verbal em morfema de gerúndio, serão dados com base na inspeção acústica que fizemos, tomando como fundamentação a teoria da Fonética Acústica, da qual trataremos a seguir. 


\subsection{Pressupostos teóricos}

\subsubsection{A Fonética Acústica: produção e percepção da fala}

Neste estudo, a inspeção acústica que fazemos toma como fundamentação conceitos sobre a produção e percepção da fala a partir de Ohala (1979). Esse pesquisador, ao se apoiar nos pressupostos teóricos de Fant (1960) sobre a teoria acústica de produção da fala, analisa o comportamento de alguns sons que são produzidos e percebidos de formas diferentes por meio de referência aos princípios da acústica.

Para o autor, os casos que envolvem alternância de som na fala ocorrem por meio de variações alofônicas, mudanças de som e/ou variação morfofonêmicas. Segundo Sweet (1888:238 apud OHALA, 1979) todas essas alternâncias do som surgem devido à "imitação acústica [falsa]", ou seja, a alternância se dá devido a um som original Y produzido em um discurso, ser substituído por um som X produzido por outro falante (o imitador). Logo, o problema, então, é descobrir por que os sons articulados diferentemente podem, apesar disso, serem acusticamente semelhantes.

Utilizando o fenômeno de redução do morfema de gerúndio como exemplo da proposta de Sweet, teremos que, quando um falante produzir [n] para um som que seria [nd], uma alternativa para um entendimento preliminar dos porquês dessa realização é olhar para os espectrogramas de [n] e compará-los aos de [nd]. No entanto, ao analisar esses padrões espectrográficos, seria necessário ter em mente o fato de que o lugar de pistas de articulação das consoantes reside na transição dos formantes e na explosão do burst. 
Ohala (1979) diz que a similaridade acústica, por exemplo, de labiais palatais (ou labiais seguidas ou co-articuladas com vogais palatais) e dentais é evidenciada pelos resultados de vários estudos de percepção da fala, como, por exemplo, os de Houser (1957), Gay (1970), Winitz et al. (1972), entre outros. O autor salienta que os estudos de cunho acústico são

De maior importância para a prática da fonologia, no entanto - ou para a linguística como um todo - não é o subconjunto de problemas com os quais pode lidar com sucesso a física - pois é provável que a física auxilie pouco na resolução de problemas de caráter sociológico ou psicológico -, mas, ao invés disso, o que a solução desses problemas nos ensina sobre a noção da explicação e sobre o papel do experimento para se chegar a explicações. (OHALA, 1979, p. 360, tradução nossa) ${ }^{5}$

Gregio et al. (2006, p. 246) tratam da relação entre produção e percepção de fala e assumem o gesto articulatório como unidade de análise para ambos os processos, fornecendo explicações tanto do que é físico/fisiológico como daquilo que é função do sistema/mental, unindo, assim, Fonética e Fonologia dentro da Linguística. Para as autoras, os modelos teóricos que abordam a fala como um sistema dinâmico permitem observar que os pesquisadores, seja partindo do ponto de vista da percepção ou da articulação, propõem um vínculo entre a Fonética e a Fonologia, a fim de explicar e contemplar todos os processos da fala. As autoras argumentam que, por meio da relação entre os aspectos físico/fisiológicos e os mentais e por meio de um embasamento teórico que considere a dinâmica da fala, há a possibilidade de reflexões diferenciadas ao abordar a fala, não somente no que concerne aos processos de desenvolvimento, mas

\footnotetext{
${ }^{5}$ Texto original: Of more importance to the practice of phonology, though - or to linguistics as a whole is not the subset of problems that can be successfully dealt with through physics - for physics is likely to be of little help in solving problems of a sociological or psychological character - but rather what the solution of these problems teaches us about the notion of explanation and about the role of experiment in arriving at explanations. (OHALA, 1979, p. 360).
} 
também aos de modificação dos sons na cadeia fônica em que a ausência de um ou mais traços motivaria alguma alteração, uma vez que a fala não é considerada uma sequência linear de fonemas e traços.

Ao contrário, considerar a fala a partir dos modelos apresentados implica considerar a alteração/modificação como consequência de gestos articulatórios resultantes. Pode-se assim, entender que um mesmo som sofre modificações quando: (i) produzido isoladamente; (ii) em co-articulação com um ou outro som; e ainda, (iii) de acordo com os fatores prosódicos envolvidos, como taxa de elocução, acento e qualidade vocal, entre outros, produzindo efeitos acústicos e perceptivos particulares.

Para as autoras, o aparato tecnológico acústico permite vincular a produção e a percepção da fala e contribui para a verificação de relações entre os aspectos acústicos (físicos/fisiológicos) e os do sistema da língua. E, assim, a investigação de como um determinado som pode ser influenciado por outro som (GREGIO et al, 2006). Desse modo, a teoria acústica de produção de fala é importante para entender as relações acústico-articulatórias, uma vez que visa a uma relação não-linear entre a articulação e a acústica, de modo que pequenas mudanças articulatórias geram grandes mudanças acústicas. Levamos em consideração essas observaçõs para investigar o fenômeno de redução de gerúndio.

Fant (1960) sugere uma não-linearidade aproximada pela linearidade, isto é, em sua teoria linear das relações fonte-filtro, alude a uma simplificação que considera a fala como linear, porém ressalta que a relação entre produção e percepção não é direta. Essa teoria propõe que o modelo de aparato do trato vocal humano é composto por: 1. Vibrador acoplado a um tubo reto (fonte de energia acústica); 2. Tubo ressoador (filtro); 3. Tubo fechado de um lado e aberto de outro. Assim, esse tubo funcionará como um filtro, ocorrendo, então, o fenômeno das ondas estacionárias. 
O nome técnico da ressonância do trato vocal é formante $(\mathrm{F})$, isto é, um modo natural de vibração do trato vocal. Normalmente, um formante é associado com um pico no espectro acústico; em conjunto, os formantes constituem a função de transferência do trato vocal. Esse processo é a relação de entrada e saída do ar e também é uma forma de descrever o processo de filtragem do tubo; por exemplo, nas relações acústico-articulatórias entre as vogais, em que o F1 relaciona-se com a altura da língua na produção das vogais, e o F2 relaciona-se com a posição antero-posterior da língua dentro da cavidade oral.

Segundo Kent \& Read (1992), as características acústicas das consoantes são mais complicadas que as das vogais. Enquanto as vogais podem ser descritas pelas mesmas características acústicas, tais como duração ou uma informação espectral, as consoantes diferem significativamente entre suas propriedades acústicas, tornando-se, assim, difícil de descrevê-las em um único jogo de medidas.

Algumas consoantes envolvem significativa produção de som, considerando que outras não possuem virtualmente nenhum componente de som. Há, por exemplo, consoantes que são produzidas com um período de obstrução completa da área vocal, e há outras que são produzidas com apenas um estreitamento do trato vocal e outras ainda que são estritamente orais na transmissão de energia acústica. Devido a essas diferenças, as consoantes são tratadas em grupos distintos, a partir de suas propriedades acústicas: oclusivas, fricativas, africadas, nasais, glides e líquidas.

Nesta dissertação, interessa estudar a consoante oclusiva /d/, cuja produção apresenta "um fechamento total do trato vocal e, dependendo de seu contexto fonético, uma soltura do fechamento e um movimento em direção de outra configuração do trato vocal” (KENT \& READ, 1992, cap. 02). No Português Brasileiro, temos as seguintes oclusivas: /p, b, t, d, k, g/. A Figura 1 a seguir indica a produção de uma oclusiva. 


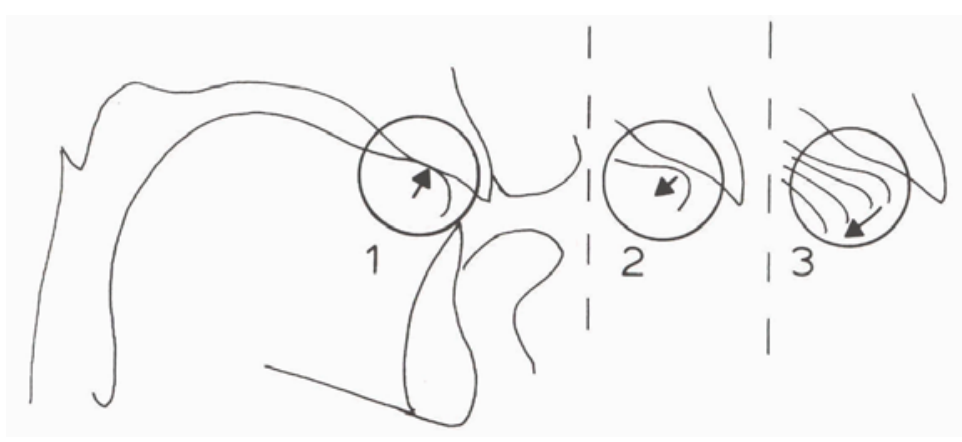

Figura 1. Eventos principais na produção das consoantes oclusivas.

(1) intervalo de obstrução do trato vocal; (2) soltura da obstrução; e (3) transição articulatória para o som seguinte.

(Fonte: KENT \& READ, 1992)

A principal característica de uma consoante oclusiva é o bloqueio momentâneo do trato vocal. Esse evento é formado por uma oclusão do articulador, podendo ocorrer em três lugares: bilabial, alveolar ou velar. Os parâmetros acústicos para a caracterização das oclusivas são: a closura - bloqueio que tem uma duração variável entre 50-100ms; o burst - explosão momentânea de ar entre 5-40ms; a transição formântica - momento da passagem da oclusiva para a vogal, que, por meio de F1, F2 e F3, dá pistas do modo e do lugar de articulação da vogal; o VOT - intervalo entre a soltura articulatória da oclusiva e o ataque das vibrações das pregas vocais, apresentando VOT com duração de $-20 \mathrm{~ms}$ a $+20 \mathrm{~ms}$ para as oclusivas vozeadas e duração de $20 \mathrm{~ms}$ a $100 \mathrm{~ms}$ para as oclusivas não-vozeadas. Segundo Kent \& Read (1992), a oclusiva alveolar [d] caracteriza-se por apresentar uma closura entre 50$100 \mathrm{~ms}$, um burst por volta de $4 \mathrm{Khz}$ e uma transição de F2 por volta de $1800 \mathrm{~Hz}$.

Na seção 3 do presente trabalho, apresentamos uma inspeção acústica sobre o apagamento do /d/ em contexto de morfema de gerúndio, com o objetivo de descrevermos as mudanças perceptivo-auditivas que envolvem a realização ou não de 
/d/, caracterizando, assim, o fenômeno variável de redução do morfema de gerúndio, por meio da teoria acústica de produção da fala (FANT, 1960).

\subsubsection{A teoria da Fonologia Lexical}

Considerando que o processo fonológico estudado na presente pesquisa ocorre em contexto morfológico, este trabalho é fundamentado nos estudos de Fonologia Lexical (doravante, FL) do Português do Brasil, pois

no modelo da FL clássica, os componentes da fonologia e da morfologia intermisturam-se, de modo que as regras fonológicas relevantes se aplicam à saída de toda regra morfológica, criando uma forma que é entrada para outra regra morfológica (LEE, 1995, p.05).

A FL é caracterizada pela interação entre a morfologia e a fonologia. Kiparsky (1982), ao analisar o inglês, diz que o léxico de uma língua está organizado em uma série de níveis, que são os domínios para regras fonológicas e morfológicas. O autor propõe quatro princípios básicos para a FL, os quais estão brevemente explicitados a seguir:

1. Hipótese de Domínio Forte (HDF): segundo essa hipótese, todas as regras fonológicas aplicam-se no nível mais alto do léxico.

2. Preservação da Estrutura (SP): por esse princípio, prevê-se que somente os segmentos contrastivos da representação subjacente (fonemas) de cada língua podem ocorrer durante as operações lexicais, de modo que a SP determina os tipos de regras fonológicas que podem se aplicar no léxico. 
3. Condição de Ciclo Estrito (SCC): esse princípio funciona como um bloqueio na aplicação das regras, ou seja, as regras fonológicas cíclicas, isto é, lexicais, aplicam-se somente em cada ciclo próprio - o ambiente derivado.

4. Hipótese de Referência Indireta (HRI): por meio desse princípio, explica-se a falta de isomorfia entre as estruturas morfológicas e fonológicas, introduzindo a noção de domínio prosódico, ou seja, as regras fonológicas aplicam-se no domínio prosódico, não no domínio morfológico.

Lee (1995), ao analisar dados do Português Brasileiro (PB), assume que há dois níveis ordenados: nível derivacional $(\alpha)$ e nível flexional $(\beta)$, que funcionam como domínios da aplicação de regras fonológicas e morfológicas, respectivamente. Seguindo o que propõe Kiparsky (1982), o autor mostra que, no PB: $1^{\circ}$ ) há dois tipos de compostos: composto lexical e composto pós-lexical; $2^{\circ}$ ) as regras lexicais sujeitam-se aos princípios da Fonologia Lexical, tais como: o Princípio de Preservação de Estrutura e a Condição de Ciclo Estrito, ao passo que as regras pós-lexicais não se sujeitam a tais princípios; $3^{\circ}$ ) em relação ao acento primário, há duas regras distintas: uma para o nãoverbo, que se aplica no nível derivacional $(\alpha)$; outra, para o verbo, que se aplica no nível flexional $\left.(\beta) ; 4^{\circ}\right)$ o acento secundário aplica-se no nível da palavra prosódica $(\omega)$.

$\mathrm{Na} \mathrm{FL}$, há dois tipos de regras fonológicas: as regras lexicais e as pós-lexicais. Estas são caracterizadas por terem aplicação variável e se aplicarem entre palavras, além de não fazerem distinção entre as mesmas, assim, são condicionadas foneticamente e podem introduzir ao léxico novos segmentos. Aquelas são caracterizadas por possuírem aplicação categórica dentro do léxico, além disso, 
preservam a estrutura da palavra, por serem sensíveis à informação morfológica. (Cf.

KIPARSKY, 1988). ${ }^{6}$

Lee (1995, p. 11) propõe o seguinte modelo da FL para o PB:

\begin{tabular}{|c|c|c|c|}
\hline O MODELO DA FL DO PB & MORFOLOGIA & & FONOLOGIA \\
\hline Nível $1(\alpha)$ & $\begin{array}{l}\text { Derivação, } \\
\text { Composição I } \\
\text { Flexão irregular }\end{array}$ & $<-->$ & $\begin{array}{l}\text { Regra } 1 \\
\text { Regra } 2 \\
\text { Regra } 3 \\
\text { : }\end{array}$ \\
\hline Nível $2(\beta)$ & $\begin{array}{c}\text { Formação Produtiva } \\
\text { Flexão Regular } \\
\end{array}$ & $<-->$ & $\begin{array}{l}: \\
:\end{array}$ \\
\hline Nível $\omega$ & -1 & $<-->$ & $\begin{array}{l}: \\
:\end{array}$ \\
\hline Pós-Lexical & Composição II & $<-->$ & \\
\hline
\end{tabular}

Esquema 1: Modelo da FL do PB

O modelo proposto por Lee, representado no Esquema 1, mostra que há apenas um componente fonológico em que há regras lexicais e pós-lexicais. O autor justifica que a postulação desse modelo deve-se à hipótese assumida sobre a interface entre a fonologia e a morfologia. Assim, segundo esse modelo, cada um dos três níveis funciona como um domínio prosódico da aplicação das regras fonológicas e morfológicas (cf. LEE, 1995).

\footnotetext{
6 "The correlation of lexical - categorizable and postlexical - unconscious is currently rather uncertain. For instance, glottalling and h-dropping are good candidates for postlexical rules, but are clear markers, or even stereotypes." A correlação de lexical - categorizável e pós-lexical - inconsciente é bastante incerto. Por exemplo, glotalização e h-queda são bons candidatos para as regras pós-lexicais, mas são indicadores claros, ou mesmo estereótipos. (McMAHON, 1991, p.30 - tradução nossa).
} 
O nível $1(\alpha)$ inclui todos os processos derivacionais, a flexão irregular e alguns processos de composição aos quais se podem acrescentar os sufixos derivacionais. Em (3), apresentamos alguns exemplos do autor (LEE, p. 12):

(3) a. [feliz], [[felic]idade]

b. [descobrir] [descoberta]

c. [[rádio-tax]ista], [[puxa-saqu]ismo]

O nível $2(\beta)$ inclui a flexão regular do verbo e do não-verbo e a formação de palavras produtivas do português, como as formações de diminutivo ("-inho", “-zinho”), advérbio (“-mente”) e grau (“-íssimo”), como exemplificam em (4)

(4) a. falo, falava

b. flor, flores

c. cafezinho

(LEE, 1995, p. 12)

O nível $\omega$ (palavra prosódica) é a saída do léxico e a entrada para a sintaxe. Pertencendo ao componente pós-lexical, esse nível prevê que a aplicação da regra é nãocíclica e não afeta as operações morfológicas.

A flexão de gerúndio, que resulta na forma verbal que investigamos, pode ser vista como pertencente ao nível $2(\beta)$, por ser uma flexão regular do verbo. Na seção 3 deste trabalho, apresentamos uma análise detalhada do fenômeno, segundo essa proposta. Além disso, discutiremos o fato de a redução de gerúndio se aplicar variavelmente, o que leva à configuração de um problema teórico, a saber: se a regra se aplica apenas ao morfema de gerúndio, então é de natureza lexical; porém essa regra tem aplicação variável, o que, como ora apresentado, é uma característica de regras póslexicais. Após a descrição do comportamento da regra de gerúndio, na variedade em 
estudo, retomaremos essa questão teórica e apresentaremos uma interpretação para os fatos encontrados.

A seguir, passamos a tratar da abordagem teórica assumida na investigação de fatores linguísticos e extralinguísticos que possam estar atuando na chamada regra de redução de gerúndio.

\subsubsection{A Variação e Mudança Linguística}

Até o século XX, segundo Alkmim (2001), os estudiosos só se preocuparam com teorias da linguagem que refletiam concepções particulares de fenômenos linguísticos, contudo, a partir do século XX, passaram a considerar a relação linguagem e sociedade. Para a autora, ao se observar a comunidade linguística (conjunto de pessoas que interagem verbalmente e que compartilham um conjunto de normas com respeito aos usos linguísticos), a constatação mais imediata é a existência de diversidade ou da variação.

Os estudos que se referem ao contexto social em que a língua é usada defendem a ideia de que muitos elementos da estrutura linguística estão implicados na variação sistemática, que reflete tanto uma mudança temporal quanto alguns processos sociais extralinguísticos.

Um dos estudiosos principais nessa área de investigação é Labov (1972), por ter observado a variação linguística relacionando-a a diferentes classes sociais, sexo, atitude profissional, etnia. Esse estudo se volta para a investigação das fronteiras existentes entre linguagem e sociedade. 
A teoria variacionista proposta por Labov (1972) busca entender a relação entre a linguagem e a sociedade, com o intuito de descrever e analisar a variação de fatos linguísticos de forma regular e sistemática da mesma maneira que outros fenômenos linguísticos não variáveis. Segundo essa proposta, a língua é heterogênea por natureza e, dada a estratificação social e a variação linguística, é relevante estudar a linguagem de maneira aprofundada no contexto social, ou seja, investiga-se como é usada em diferentes contextos sociais, opondo-se à visão de que a variação seja um simples desvio de uma norma padrão. Para Labov, a heterogeneidade da língua não é apenas um resultado da interação entre fatores linguísticos, mas é também um sistema altamente regrado, que deve ser analisado na correlação com fatores sociais.

A metodologia da teoria variacionista de Labov (1972) visa a uma investigação empírica que consiste em localizar e contactar os informantes num determinado lugar, levar em consideração a natureza do discurso, a função da linguagem e os contextos de aplicação da regra variável, para elaborar questões que serão feitas ao informante, no momento da coleta de dados, lembrando-se sempre de que se devem obter amostras de fala mais próximas do contexto natural de sua produção. Somente por meio do registro da fala em áudio é que se pode proceder a uma observação sistemática da fala de uma comunidade.

A partir do estudo da variação, Labov (1972) descreve os objetos da descrição linguística, isto é, discute a noção de dialeto e idioleto. A primeira noção é entendida como variedade que, gramaticalmente e/ou fonologicamente, é distinta de outras variedades da língua. Já a segunda noção, proposta inicialmente por Bloch (1948), é a maneira de falar característica de um determinado interlocutor. Assim, Labov salienta que a investigação sociolinguística procura responder a cinco questões gerais: 
1. Qual é a forma da regra lingüística? E que restrições podem incidir sobre ela?

2. Quais são as formas subjacentes sobre as quais as regras operam, e como podem ser precisamente determinadas em cada caso?

3. Como as regras se combinam em sistemas? E como estão ordenadas dentro desses sistemas?

4. Como os sistemas se inter-relacionam em situações bilíngües e polissistêmicas?

5. Como as regras e os sistemas de regras mudam? Qual é o mecanismo dos processos fundamentais de aquisição da língua? Como mudam as regras no curso da evolução lingüística? (LABOV, 2008 [1972], p. 241).

Labov (1972) argumenta também sobre a relação entre normas e comportamentos; para tanto, o autor discute o que as pessoas dizem e o que realmente as pessoas acham que deveriam dizer. Segundo Labov (1972), "um número de marcadores sociolinguísticos ascendem à consciência social explícita e se tornam estereótipos (...), esses estereótipos sociais oferecem uma visão fragmentada da estrutura linguística” (p. 287).

Wolfram \& Fasold (1974) argumentam que existe uma espécie de julgamento das características sociais de um indivíduo por recurso ao seu modo de falar; logo, para esses autores, do mesmo modo que há classes sociais, também há dialetos sociais, o que implica dizer que não há uma variedade melhor ou pior. O que deve ser uma premissa para o linguista é que todas as línguas ou dialetos são adequados como sistemas comunicativos. Toda língua é um fenômeno humano que caracteriza o grupo social, e todos os sistemas das línguas são perfeitamente adequados como sistemas comunicativos para os membros do grupo social. Assim, a aceitabilidade social de uma variedade particular não está relacionada à adequação ou não do seu código comunicativo, mas a valores sociais, políticos e culturais. É comum uma cultura socialmente dominante considerar inadequados os meios de comunicação da camada 
social subordinada. Essa visão é uma manifestação do etnocentrismo linguístico das classes dominantes.

Com relação às normas das línguas, Wolfram \& Fasold (1974) afirmam que a noção de correção está relacionada às normas de um comportamento apropriado da fala. A escolha de uma variedade como norma culta pode ser determinada de várias formas, entre elas: a língua falada pela classe socioeconômica mais abastada e a língua não falada pelos mais carentes socioeconomicamente. O comportamento de fala de um grupo estigmatizado socialmente será também estigmatizado, ao passo que a variedade falada pelo grupo mais rico socioeconomicamente será prestigiada. Os autores argumentam que há dois tipos de estandardização: (i) o formal, que se refere ao uso prescrito por gramáticas e dicionários; e (ii) o informal, que não tem amparo dos livros, mas que é muito mais efetivo.

Alkmim (2001) também discute essa valoração das variedades linguísticas, a qual reflete a hierarquia dos grupos sociais. Para a autora, há variedades prestigiadas e estigmatizadas. Na primeira, há uma variedade padrão, que é socialmente mais valorizada, variedade esta que estabelece um conjunto de normas que definem o modo "certo" de falar. Contudo, reafirmando os dizeres de Wolfram \& Fasold, a autora salienta que a variedade padrão não detém propriedades intrínsecas que garantam uma qualidade superior às demais. Para a Linguística, segundo a autora, toda língua é adequada à comunidade que a utiliza, sendo um sistema completo que permite a um povo exprimir o mundo físico e simbólico em que vive. Assim, os julgamentos sociais ante a língua se baseiam em critérios não linguísticos: são de natureza política e social, gerando diversos preconceitos sociais.

Para Labov (1972, p. 290), 
algum suporte empírico para postular a oposição entre dois conjuntos de valores quanto ao correlato normativo de marcadores sociolingüísticos estáveis (...) o objeto apropriado de estudo não deve ser só o comportamento, ou só as normas, mas sim o grau em que (e as regras pelas quais) as pessoas se desviam das normas explícitas que elas sustentam. É nesse nível de abstração que podemos desenvolver melhor a teoria lingüística e sociolingüística.

Para Labov, a linguagem também é um indicador de mudança social, pois a forma do comportamento linguístico muda com rapidez quando muda a posição social do falante. $\mathrm{Na}$ "evolução" da linguagem, casos de variação podem vir a configurar mudanças estruturais no sistema da língua. Como exemplo de mudança linguística no $\mathrm{PB}$, cita-se o caso da hoje considerada forma pronominal você, a qual, originada da forma de tratamento "vossa mercê", tem como alternante a forma "ce", uma forma cliticizada que marca segunda pessoa do discurso. Logo, é válido salientar que estudar a variação é muito importante, pois, na variação podemos identificar a instauração de mudanças.

Assim, as línguas mudam com o passar do tempo, ou seja, elas não constituem realidades estáticas; ao contrário, sua configuração estrutural se altera continuamente no tempo. É importante destacar que

a mudança gera contínuas alterações da configuração estrutural das línguas sem que, no entanto, se perca, em qualquer momento, aquilo que costuma ser chamado de plenitude estrutural e potencial semiótico das línguas (...) as línguas mudam, mas continuam organizadas e oferecendo a seus falantes os recursos necessários para a circulação dos significados. Os falantes normalmente não têm consciência de que sua língua está mudando (FARACO, 2005, p. 14).

As mudanças atingem sempre partes e não o todo da língua, o que significa que a história das línguas se faz num complexo jogo de mutação e permanência, reforçando aquela imagem antes estática do que dinâmica que os falantes têm de sua língua. Assim, 
segundo o autor, é tão claro que a língua se transforma ao longo do tempo, que estruturas e palavras que existiam antes não ocorrem mais ou estão deixando de ocorrer; ou, então, elas tiveram modificação em sua forma, função e/ou significado.

Para Labov, a percepção das mudanças não se dá apenas entre manifestações linguísticas afastadas no tempo, chamada mudança em tempo real, mas também no tempo presente, chamada de mudança em tempo aparente. A mudança em tempo aparente é a dimensão em que se examina a mudança por meio "das comprovações internas, na distribuição do comportamento linguístico através das várias faixas etárias da população" (LABOV, 2008 [1972], p. 163).

Weireich, Labov \& Herzog (2005) salientam que é preciso notar que nem toda variação implica mudança, mas toda mudança pressupõe variação, o que significa, em outros termos, que a língua é uma realidade heterogênea, multifacetada e que as mudanças emergem dessa heterogeneidade.

No que diz respeito ao objeto de investigação desta dissertação, de uma perspectiva da teoria variacionista, encontramos em Mollica (1989) um estudo da assimilação de /ndo/ em /no/, como em 'faze[ndo]' 'faze[no]', no dialeto da cidade do Rio de Janeiro. Além desse processo, a pesquisadora investigou a alternância das líquidas como em '[Fla]mengo' '[Fra]mengo' e a assimilação de $/ \mathrm{mb} / \mathrm{a} / \mathrm{m} / \mathrm{como}$ em ‘ta[mb]ém' $\sim$ 'ta[m]ém'. Para cada processo, foram testadas as mesmas variáveis sociais: escolaridade, idade e sexo, mercado ocupacional, sensibilidade linguística, renda e bairro. A pesquisadora mostra que o fator idade é relevante na aplicação dos três processos, pois os dados revelam um resultado diferente do esperado, particularmente para informantes da faixa etária de 7 a 14 anos. Esses informantes mais jovens empregam mais a variante de prestígio em relação às outras faixas etárias, enquanto o esperado era que os informantes mais jovens empregassem menos a variante de 
prestígio, cujo emprego iria aumentando à medida que aumenta os níveis da faixa etária. Assim como Mollica (1989), investigamos a assimilação /ndo/ /no/ e buscamos avançar na análise do fenômeno fonológico para o PB, considerando tanto os fatores extralinguísticos quanto os linguísticos que não foram considerados para o estudo do dialeto carioca.

Para responder o que condiciona a aplicação variável da regra de apagamento do /d/ em morfema de gerúndio, buscaremos correlações no cruzamento de variáveis linguísticas e sociais. Procuraremos mostrar como que, na variedade paulista estudada, a regra de assimilação afeta a forma de gerúndio de forma variável.

Na próxima seção, passamos a tratar dos passos metodológicos adotados no desenvolvimento de nossa pesquisa, bem como a caracterizar a comunidade de fala estudada.

\subsection{Resumo}

Nessa seção, tratamos dos estudos sobre o fenômeno fonológico da redução do morfema de gerúndio, em que o morfema /ndo/ se reduz a [no] na língua falada, comportando-se como uma regra variável que ocorre no PB. Como mostramos, esse fenômeno já aparece registrado mesmo antes de Amaral (1920), e já se apresenta na formação da língua portuguesa.. Hoje, disseminado em grande parte do território brasileiro, há registros da redução do gerúndio na fala de Rio Grande do Sul, Paraná, São Paulo, Minas Gerais, Sergipe, Alagoas, Pernambuco, Goiás e Rio de Janeiro. (cf. MELO, 1946; NASCENTES, 1950; SILVA NETO, 1952; COUTINHO, 1967; 
MOLLICA, 1989; CRISTÓFARO SILVA, 1996; MARTINS, 2001; HONÓRIO, 2005; MARTINS, 2006).

Observamos que a denominação do fenômeno fonológico de redução do morfema de gerúndio varia de autor para autor, uns caracterizam-no como assimilação, outros como apagamento. Atualmente, o fenômeno é descrito como caso de assimilação, no entanto, também envolve processo de apagamento de segmento consonantal. Assim, devido à eliminação da consoante /d/ ser mais perceptível para o ouvinte, assumimos, aqui, que o processo é mais bem descrito como caso de apagamento de /d/.

Como pontos centrais da presente seção, retomamos as noções básicas das teorias que embasaram o nosso trabalho e que se mostram pertinentes para a descrição do nosso objeto de estudo. São três os arcabouços teóricos que articulamos neste trabalho. Para a realização da inspeção acústica, nos valemos da teoria Acústica sobre produção e percepção da fala (FANT, 1960), na subseção (1.3.1), que tem como ponto principal a análise do comportamento de alguns sons que são produzidos e percebidos de formas diferentes, por meio de referência aos princípios da acústica, vinculando Fonética a Fonologia para explicar os processos fonológicos da fala. Para a descrição e interpretação fonológica que fazemos, adotamos a Fonologia Lexical (LEE, 1995), na subseção (1.3.2), que se mostra relevante porque considera que o léxico de uma língua está organizado em níveis que se sujeitam a princípios que determinam a aplicação ou o bloqueio de um processo fonológico que seja condicionado por fatores morfofonológicos. Por fim, a teoria variacionista (LABOV, 1972), na subseção (1.3.3), também se mostra pertinente porque sua metodologia busca analisar a linguagem em seu contexto sociocultural, por meio de uma investigação empírica, observando o comportamento dos falantes de uma comunidade de fala. Assim, a descrição da regra 
variável de apagamento do /d/ sob esta perspectiva possibilita a sistematização dessa variação, por meio da observação de fatores sociais e linguísticos. 


\section{MATERIAL E MÉTODO}

A presente seção apresenta as etapas metodológicas que nortearam esta pesquisa. Utilizamos os pressupostos metodológicos da teoria sociolinguística proposta por Labov (1972), visto que os informantes da comunidade de fala abordada realizam o apagamento do /d/ do morfema de gerúndio como regra variável como já verificamos anteriormente (FERREIRA, 2007) e também em outros autores que descreveram o mesmo fenômeno para diferentes regiões (AMARAL, 1920; MARROQUIM, 1934; TEIXEIRA, 1938; CRISTÓFARO SILVA, 1996; MOLLICA, 1989; MARTINS, 2001; DALPIAN E MÉA, 2002; HONÓRIO, 2005).

Esta seção está composta da seguinte maneira: na subseção (2.1), conceituamos a comunidade de fala adotada neste trabalho e caracterizamos historicamente a região de São José do Rio Preto; em (2.2), descrevemos o banco de dados Iboruna; em (2.3), delineamos a composição da subamostra utilizada na análise variacionista; em (2.4), justificamos a realização de uma investigação de natureza acústica de base experimental; em (2.5), apresentamos os fatores de análise da pesquisa variacionista; em (2.6), relatamos os passos metodológicos da quantificação e da análise variacionista dos dados.

\subsection{A comunidade de fala}

O conceito de comunidade de fala abordado neste trabalho é o mesmo proposto por Labov (1972). Para esse autor, a comunidade de fala é definida pela participação num conjunto de normas compartilhadas. Assim, ao se observar o comportamento 
linguístico, é possível fazer estudos detalhados da estrutura de estratificação de classe numa dada comunidade. Nas pesquisas de Labov, verificou-se que existem algumas variáveis linguísticas correlacionadas com uma medida abstrata de posição de classe social, derivada de uma combinação de vários indicadores não-isomórficos, em que nenhuma medida única, menos abstrata, vai gerar correlações igualmente boas. Nesse sentido, segundo Labov, os falantes mais velhos e mais jovens da cidade de Nova York pertencem a comunidades de fala ligeiramente diferentes. (Cf. LABOV, 1972, p. 150188).

Em nossa pesquisa, a comunidade de fala estudada é representada por um grupo de falantes que compartilha as mesmas normas da língua; esse grupo está descrito mais adiante quando mencionamos sobre a subamostra de dados da região de São José do Rio Preto. Antes de descrever o nosso corpus de pesquisa, caracterizamos a região em estudo apresentando um breve histórico sócio-econômico e sua situação atual, seguida da apresentação do banco de dado Iboruna, do qual foram extraídas as gravações que compõem a nossa subamostra.

\subsubsection{Breve história da região de São José do Rio Preto ${ }^{7}$}

O município de São José do Rio Preto foi fundado em 1852 e sua história inicia-se com o desbravamento e a ocupação do solo do sertão paulista, em meados do século XIX, por mineiros que se fixaram na região.

\footnotetext{
${ }^{7}$ A elaboração desse histórico da formação da região de São José do Rio Preto baseia-se na Conjuntura de São José do Rio Preto (2009) e no Perfil regional desenvolvido pela Assessoria de Gestão Estratégica da Secretaria de Economia e Planejamento. Disponível em: $<$ http://www.planejamento.sp.gov.br/des/textos8/SJRioPreto.pdf $>$.
} 
A fundação ocorreu a partir da doação de terras feita por Luiz Antônio da Silveira, ao seu santo protetor, São José, para que do patrimônio originasse uma cidade. Em 19 de março de 1852, João Bernardino de Seixas Ribeiro (o fundador de São José do Rio Preto) liderou os moradores das vizinhanças, que ergueram um cruzeiro de madeira e edificaram uma pequena capela para as funções religiosas.

Em 1894, ocorreu a emancipação política da cidade, quando São José do Rio Preto se desmembrou de Jaboticabal, transformando-se em município. A região era um imenso território, limitado pelos rios Paraná, Grande, Tietê e Turvo, com mais de 26 mil $\mathrm{km}^{2}$ de superfície. Hoje, a área total da cidade é de $431,38 \mathrm{~km}^{2}$, sendo área urbana de $117,43 \mathrm{~km}^{2}$. Localizada ao noroeste do estado de São Paulo, a cidade está a $451 \mathrm{~km}$ da capital do estado e a $710 \mathrm{~km}$ da capital do país, Brasília.

Em 1904, foi criada a Comarca de Rio Preto. Em 1912, com a chegada da Estrada de Ferro Araraquarense (EFA), a cidade transforma-se em um pólo comercial de grande relevância no então conhecido "Sertão de Avanhandava". Em 1945, retoma o nome original de São José do Rio Preto, o qual nasce da junção dos nomes do padroeiro da cidade, São José, e do rio que corta o município, o Rio Preto. 


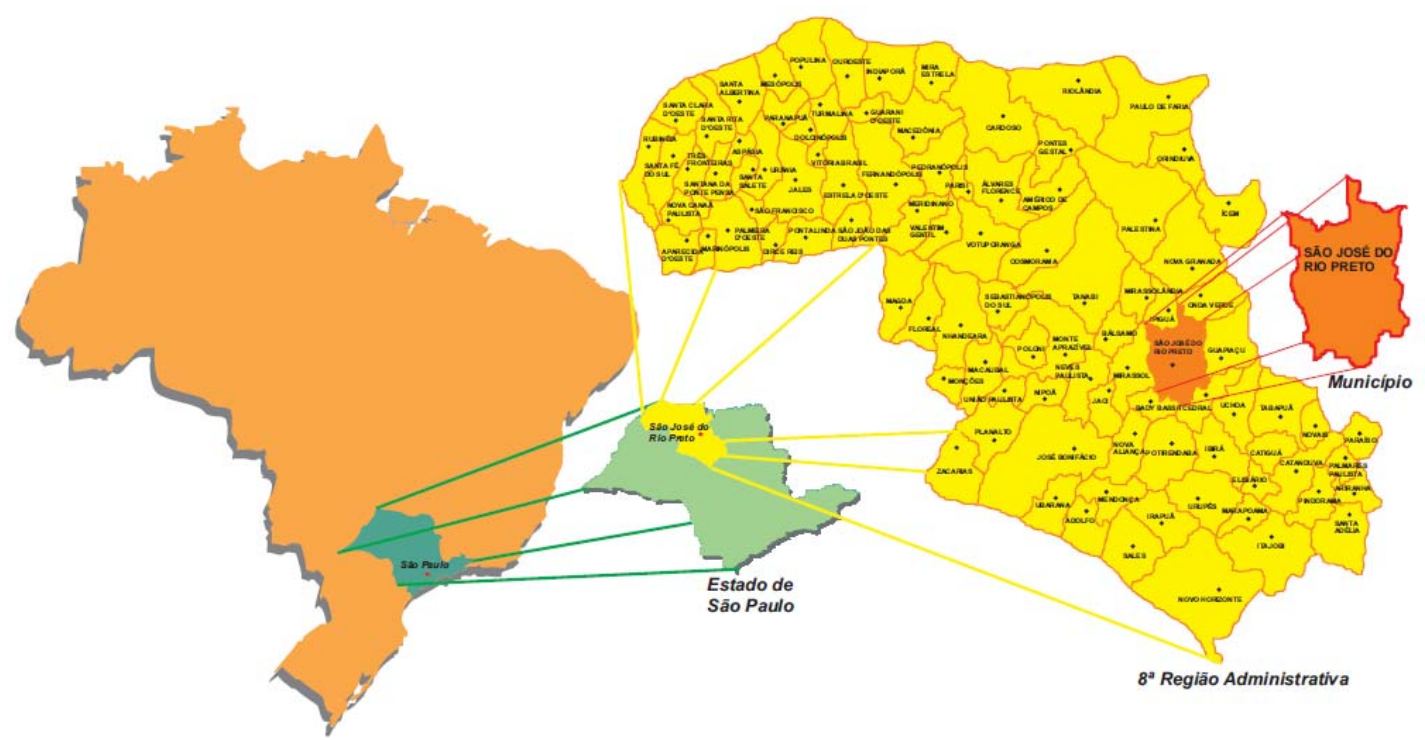

Figura 2. Mapa do Brasil, Estado, Região Administrativa e Município de São José do Rio Preto.

(Fonte: Secretaria Municipal de Planejamento e Gestão Estratégica) (CONJUNTURA, 2009, p.04).

A região destacou-se, em meados da década de 1930, como grande área agropecuária de São Paulo, integrada à dinâmica da economia paulista, respondendo por cerca de $14 \%$ da produção agrícola e $20 \%$ dos efetivos bovinos do Estado. O café era, então, a cultura economicamente mais importante, respondendo por cerca de $63 \%$ do valor da produção agropecuária regional e 17\% da área cultivada com café do Estado de São Paulo.

A região constitui, hoje, importante centro comercial e de serviços, industrial e médico hospitalar, exercendo atração sobre ampla área geográfica, que ultrapassa os limites do estado de São Paulo, atingindo municípios de estados vizinhos, como os do sudoeste de Minas Gerais, do sul de Goiás e do nordeste do Mato Grosso do Sul.

Atualmente, São José do Rio Preto é sede da região administrativa do noroeste paulista, que comporta 96 municípios que, juntos, ocupam uma área de $25.476 \mathrm{~km}^{2}$, ou 
$10,2 \%$ do total estadual. ${ }^{8}$ Os municípios que fazem limite com a cidade são de pequeno porte, a saber: Bady Bassitt, Cedral, Guapiaçu, Ipiguá, Mirassol e Onda Verde.

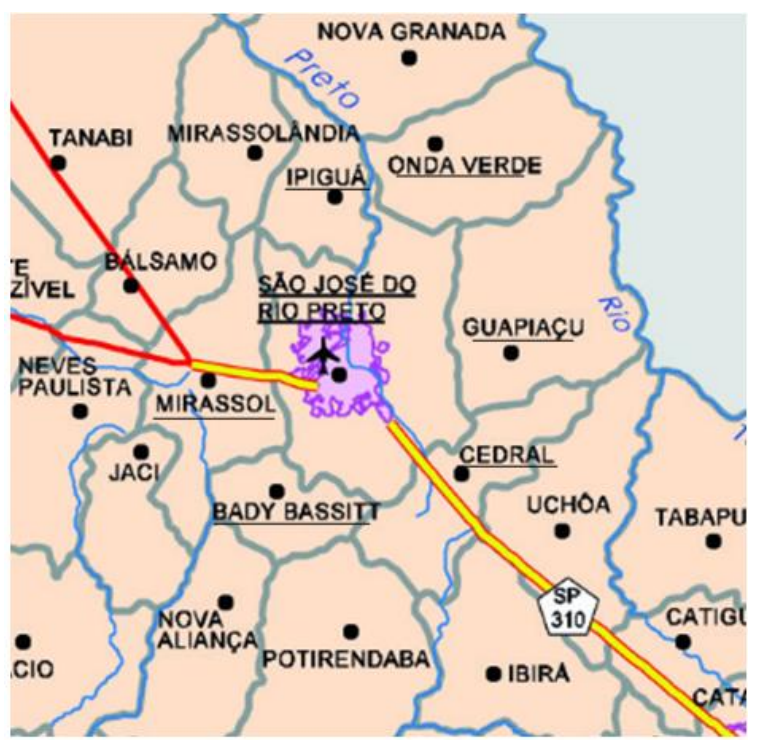

Figura 3. Mapa da região administrativa de São José do Rio Preto e os municípios fronteiriços (nomes grifados - grifo nosso)

(Fonte: DER Mapa Rodoviário do Estado de São Paulo, 2002)

\footnotetext{
${ }^{8}$ Os 96 municípios que compõem a RA de São José do Rio Preto são: Adolfo, Álvares Florence, Américo de Campos, Aparecida d'Oeste, Ariranha, Aspásia, Bady Bassitt, Bálsamo, Cardoso, Catanduva, Catiguá, Cedral, Cosmorama, Dirce Reis, Dolcinópolis, Elisiário, Estrela d'Oeste, Fernandópolis, Floreal, Guapiaçu, Guarani d'Oeste, Ibirá, Icém, Indiaporã, Ipiguá, Irapuã, Itajobi, Jaci, Jales, José Bonifácio, Macaubal, Macedônia, Magda, Marapoama, Marinópolis, Mendonça, Meridiano, Mesópolis, Mira Estrela, Mirassol, Mirassolândia, Monções, Monte Aprazível, Neves Paulista, Nhandeara, Nipoã, Nova Aliança, Nova Canaã Paulista, Nova Granada, Novais, Novo Horizonte, Onda Verde, Orindiúva, Ouroeste, Palestina, Palmares Paulista, Palmeira d'Oeste, Paraíso, Paranapuã, Parisi, Paulo de Faria, Pedranópolis, Pindorama, Planalto, Poloni, Pontalinda, Pontes Gestal, Populina, Potirendaba, Riolândia, Rubinéia, Sales, Santa Adélia, Santa Albertina, Santa Clara d'Oeste, Santa Fé do Sul, Santa Rita d'Oeste, Santa Salete, Santana da Ponte Pensa, São Francisco, São João das Duas Pontes, São José do Rio Preto, Sebastianópolis do Sul, Tabapuã, Tanabi, Três Fronteiras, Turmalina, Ubarana, Uchôa, União Paulista, Urânia, Urupês, Valentim Gentil, Vitória Brasil, Votuporanga e Zacarias. Dados divulgados em $14 / 08 / 2009$

site:http://www.ibge.gov.br/home/presidencia/noticias/noticia_visualiza.php?id noticia=1435\&id pagina $=1$. Fonte: IBGE/http://www.ibge.gov.br/home/estatistica/populacao/
} 


\subsubsection{Panorama atual da comunidade de fala}

Na região de São José do Rio Preto, predomina uma população economicamente ativa e as atividades econômicas estão divididas em vários setores, porém as que se destacam na economia do município são: prestação de serviços, comércio, indústria, entre outras, como mostra o gráfico a seguir:

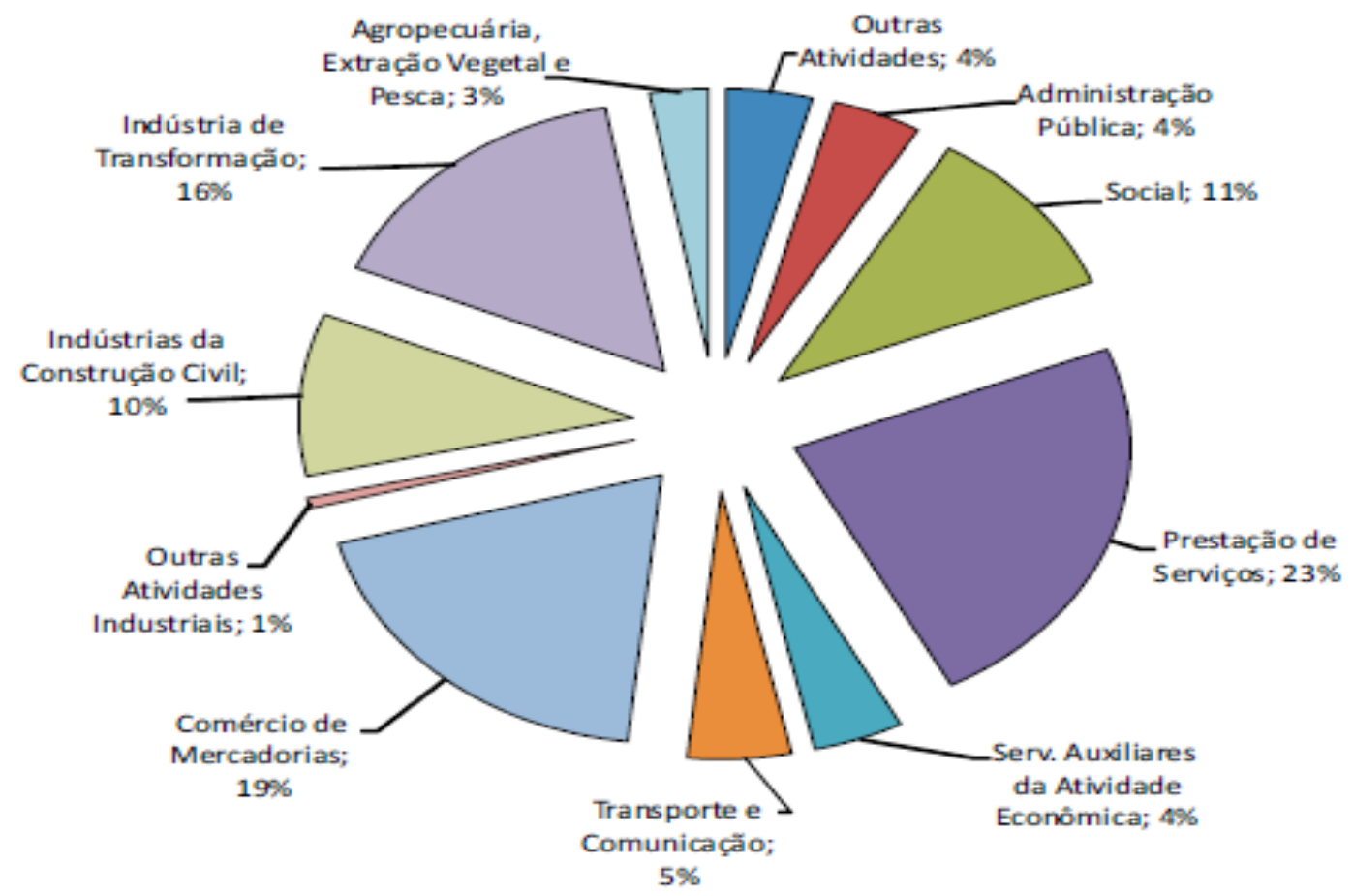

Gráfico 1. Percentual das atividades econômicas desenvolvidas em São José do Rio Preto

(Fonte: CONJUNTURA, 2009, p. 25)

São José do Rio Preto tem sido destaque na região por possuir nível elevado de riqueza e bons níveis nos indicadores sociais. ${ }^{9}$ Em 2008, a cidade registrou um crescimento de 4,6\% no IME-R (Indicador de Movimentação Econômica Regional), o

\footnotetext{
${ }^{9}$ Cf. A título de exemplificação desses dados, os índices da cidade de São José do Rio Preto encontram-se no levantamento do Índice Paulista de Desenvolvimento, realizado pela Fundação SEADE: http://www.planejamento.sp.gov.br/des/textos8/SJRioPreto.pdf
} 
que permite fazer uma estimativa do PIB (Produto Interno Bruto) do município, que resulta em um valor estimado de cerca de $\mathrm{R} \$ 7,42$ bilhões. ${ }^{10}$ Para os administradores, a cidade viveu, no ano de 2008, um dos momentos mais importantes de sua história: foi a $59^{\mathrm{a}}$ maior economia do Brasil e a $18^{\mathrm{a}}$ do Estado de São Paulo.

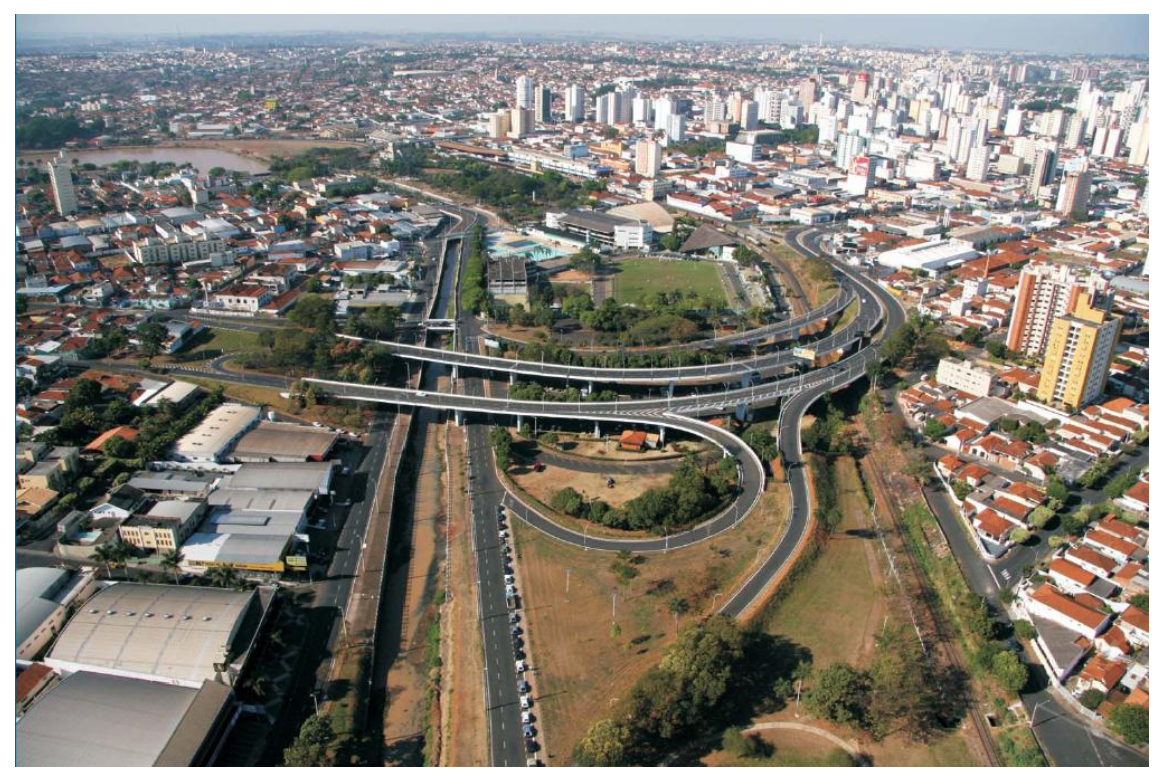

Figura 4. Foto da cidade de São José do Rio Preto (SP): Av. Philadelpho Gouvea Neto e ViadutoJordão Reis (Foto - Paulo Magri)

(Fonte: CONJUNTURA, 2009)

Na cidade de São José do Rio Preto, em julho de 2008, a população era de cerca de 414.272 habitantes, que somados à população dos outros municípios que compõem a região administrativa perfazem cerca de 1.454 .405 habitantes. A pessoa nascida em São José do Rio Preto é tratada pelo gentílico: riopretano ou riopretense. ${ }^{11}$

A população caracteriza-se, no tocante à faixa etária, por apresentar uma diminuição no número de crianças e um aumento da população de idosos do ano 2000 para 2009. Abaixo encontram-se os gráficos comparativos, por grupos de idade

\footnotetext{
10 Prefeitura Municipal de São José do Rio Preto: $\frac{\text { http://www.riopreto.sp.gov.br/PortalGOV/cache/home.html }}{{ }^{11} \text { Fonte: IBGE - Disponível em: http://www.ibge.gov.br/cidadesat/topwindow.htm?1. Acesso em: } 13 \mathrm{dez}}$ de 2009.
} 


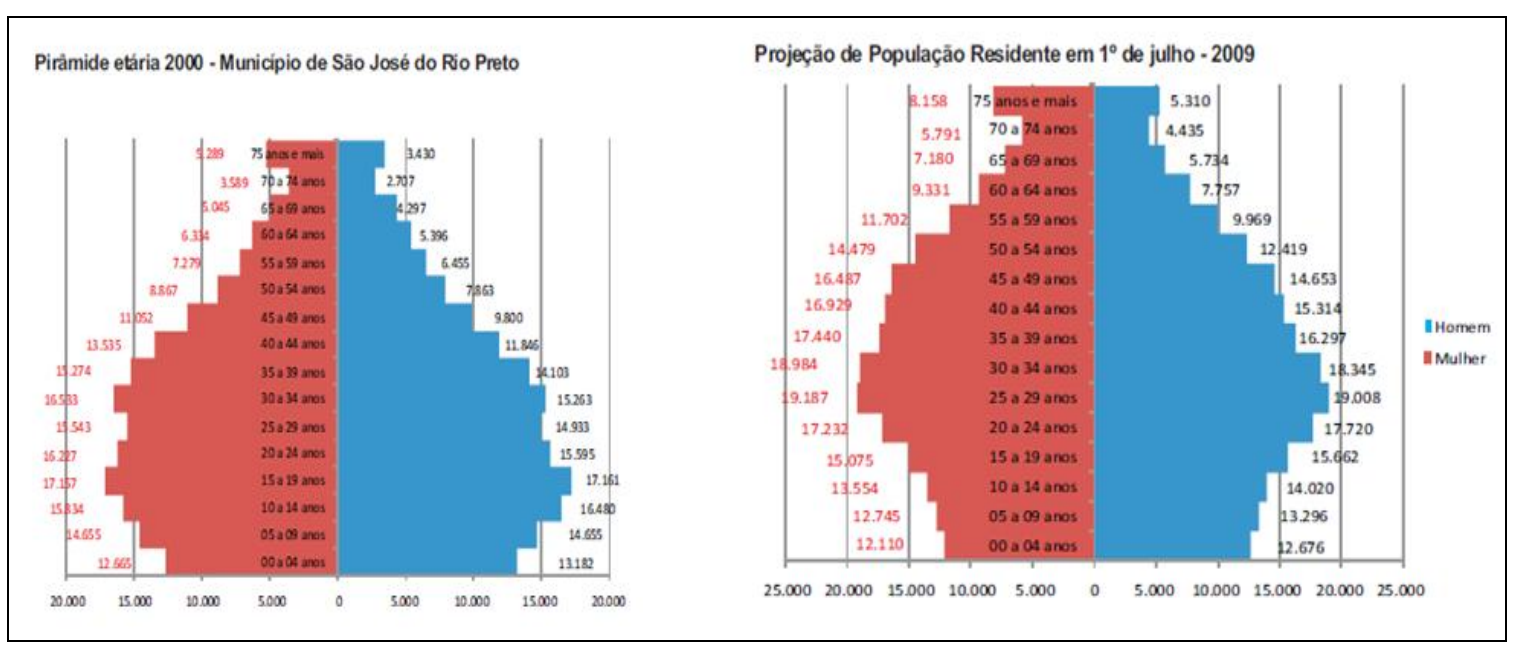

Gráfico 2. Comparação de número de habitantes por grupos de idade entre o ano de 2000 e o de 2009. (Fonte: CONJUNTURA, 2009)

Ao observar as pirâmides do Gráfico 2, nota-se que a população de crianças diminuiu enquanto a população de adultos com mais de 20 anos aumentou no período considerado, logo, podemos dizer que a comunidade de fala riopretense é composta mais por adultos e idosos do que por crianças e adolescentes. Esse fato pode ser associado à diminuição das taxas de fecundidade e natalidade no período abordado.

Quanto ao sexo da população, há mais mulheres do que homens, segundo os dados da Conjuntura econômica de 2009 realizada pela prefeitura municipal: há cerca de 214.032 mulheres e cerca de 200.240 homens. Quanto à ocupação, cerca de 390.130 habitantes riopretenses residem na zona urbana e cerca de 24.142 habitantes, na zona rural o que caracteriza uma comunidade urbana. A Tabela 1 mostra a relação entre esses dois fatores 
Tabela 1. Estimativa populacional 2008 de São José do Rio Preto/SP ${ }^{12}$

\begin{tabular}{c|c|c|c}
\hline $\begin{array}{c}\text { Sexo } \\
\text { Localidade }\end{array}$ & Homens & Mulheres & Total \\
\hline Urbano & 187.635 & 202.495 & $\mathbf{3 9 0 . 1 3 0}$ \\
Rural & 12.605 & 11.237 & $\mathbf{2 4 . 1 4 2}$ \\
\hline Total & $\mathbf{2 0 0 . 2 4 0}$ & $\mathbf{2 1 4 . 0 3 2}$ & $\mathbf{4 1 4 . 2 7 2}$ \\
\hline
\end{tabular}

Quanto aos indicadores da educação, a região administrativa de São José do Rio Preto tem uma população com alto índice de alfabetização. Na Tabela 2, mostramos a porcentagem dos habitantes alfabetizados, por anos de escolaridade.

Tabela 2. Frequência e percentual de pessoas alfabetizadas, por região Macro, Micro e Município de São José do Rio Preto e por anos de escolarização.

\begin{tabular}{|c|c|c|c|c|c|c|}
\hline \multicolumn{7}{|c|}{ Pessoas de 10 anos ou mais de idade } \\
\hline Região de SJRP & $\begin{array}{l}\text { Macro-re } \\
\text { SJRP }\end{array}$ & ão $\quad$ de & $\begin{array}{l}\text { Micro-reg } \\
\text { SJRP }\end{array}$ & de & $\begin{array}{l}\text { Municípi } \\
\text { SJRP }\end{array}$ & de \\
\hline \multirow{2}{*}{$\begin{array}{l}\text { Anos de } \\
\text { escolaridade }\end{array}$} & Total de hab. & 1.209 .406 & Total de hab. & 570.168 & Total de hab. & 306.539 \\
\hline & \multicolumn{2}{|c|}{ Alfab./(\%) } & \multicolumn{2}{|c|}{ Alfab./(\%) } & \multicolumn{2}{|c|}{ Alfab./(\%) } \\
\hline 1 a 4 anos & \multicolumn{2}{|c|}{$412.219(34 \%)$} & \multicolumn{2}{|c|}{$181.362(32 \%)$} & \multicolumn{2}{|c|}{$83.417(27 \%)$} \\
\hline 5 a 8 anos & \multicolumn{2}{|c|}{$319.205(27 \%)$} & \multicolumn{2}{|c|}{$157.301(28 \%)$} & \multicolumn{2}{|c|}{$86.177(28 \%)$} \\
\hline 9 a 11 anos & \multicolumn{2}{|c|}{$254.179(21 \%)$} & \multicolumn{2}{|c|}{$128.832(23 \%)$} & \multicolumn{2}{|c|}{$76.149(25 \%)$} \\
\hline 12 a 13 anos & \multicolumn{2}{|c|}{$25.455(3 \%)$} & \multicolumn{2}{|c|}{$13.102(2 \%)$} & \multicolumn{2}{|c|}{$9.529(3 \%)$} \\
\hline 14 anos ou mais & \multicolumn{2}{|c|}{$84.177(7 \%)$} & \multicolumn{2}{|c|}{$45.473(8 \%)$} & \multicolumn{2}{|c|}{$32.450(10 \%)$} \\
\hline Total & \multicolumn{2}{|c|}{$1.095 .235(90 \%)$} & \multicolumn{2}{|c|}{$526.070(92 \%)$} & \multicolumn{2}{|c|}{$287.722(94 \%)$} \\
\hline
\end{tabular}

A Tabela 2 mostra que a macrorregião administrativa de São José do Rio Preto apresenta uma média de $90 \%$ dos habitantes escolarizados; a microrregião, comunidade de fala alvo de nossa pesquisa, apresenta $92 \%$ da população alfabetizada e o município de São José do Rio Preto, pólo regional, 94\% dos habitantes escolarizados. Tais indicadores percentuais colocam a região de São José do Rio Preto em $3^{\circ}$ lugar em escolaridade no estado de São Paulo.

\footnotetext{
${ }^{12}$ Fonte: Secretaria Municipal de Planejamento e Gestão Estratégica/IBGE base Censo 2000 e Contagem e Estimativa 2008.
} 


\subsection{Caracterização do banco de dados Iboruna}

Nesta pesquisa, utilizamos o banco de dados Iboruna (Rio Preto em tupiguarani). O Iboruna foi composto de março de 2004 a outubro de 2007, projeto que partiu do Grupo de Pesquisa em Gramática Funcional. Trata-se do primeiro banco de dados com amostras de fala do interior do Estado de São Paulo, coletadas sob rigoroso controle de fatores sociais.

O banco de dados é composto de dois tipos de amostra de fala: Amostra Comunidade (ou Amostra Censo), AC, que reúne 151 amostras de fala controladas sociolinguisticamente, e Amostra de Interação Dialógica, AI, que reúne 11 amostras de fala coletadas secretamente em situações livres de interação social. Nesta pesquisa, utilizaremos apenas inquéritos da Amostra Censo (GONÇALVES, 2008).

Os inquéritos da AC são provenientes da cidade de São José do Rio Preto e as seis cidades fronteiriças do noroeste paulista, a saber: Bady Bassit, Cedral, Guapiaçu, Ipiguá, Mirassol e Onda Verde. Para a coleta das amostras, os informantes foram estratificados em: (i) sexo/gênero (masculino/feminino), (ii) faixa etária (de 7 a 15 anos; de 16 a 25 anos; de 26 a 35 anos; de 36 a 55 anos; mais de 55 anos), (iii) nível de escolaridade ( $1^{\circ}$ Ciclo do Ensino Fundamental; $2^{\circ}$ Ciclo de Ensino Fundamental; Ensino Médio; Ensino Superior); e (iv) renda familiar (mais de 25 salários mínimos; de 11 a 24 salários mínimos; de 6 a 10 salários mínimos; até 5 salários mínimos).

Além do perfil social determinado pelo intercruzamento dessas variáveis, os informantes do censo linguístico são nativos de cidades abrangidas pelo banco de dados e/ou residem em uma delas desde, pelo menos, os cinco anos de idade.

Para a coleta dos dados, foi realizada a gravação de uma entrevista, durante a qual cada informante, em aproximadamente uma hora, produziu cinco tipos de texto 
oral: (i) narrativa de experiência pessoal; (ii) narrativas recontadas; (iii) texto descritivo; (iv) relatos de procedimentos; (v) relatos de opinião. Em nossa pesquisa, não são analisados os cinco tipos de textos como uma variável lingüística, pois restringimos para análise variacionista apenas as narrativas de experiência pessoal, a justificativa dessa seleção encontra-se na próxima subseção.

Vale observar que acompanha cada um dos inquéritos de fala um relatório das condições de coleta das amostras, composto de uma Ficha Social e de um Diário de Campo. No primeiro, constam os dados pessoais de cada informante (nome; data de nascimento; naturalidade; endereço; telefone; sexo; profissão; escolaridade; renda familiar e o nome do documentador). No segundo, estão descritos os comentários mais relevantes acerca da coleta da entrevista como: data da coleta; caracterização física do local escolhido; relação entre entrevistador e informante; disposição do informante para com a gravação; ocorrência ou não de intervenções de terceiros; entre outros. O acesso a essas informações torna-se relevante uma vez que pode servir de auxílio na análise dos dados.

O armazenamento digital das entrevistas contribui para sua boa qualidade acústica, o que é muito importante para a análise dos dados deste estudo. Para a prévia identificação das palavras nos contextos relevantes, contamos com a transcrição dos inquéritos, feitas a partir de um manual de transcrição ortográfica, que visa à homogeneização da representação do material escrito dos dados. ${ }^{13}$

O Iboruna é um banco de médio porte, que comporta em sua base cerca de 1.500.000 palavras contidas no material transcrito. Esse total de palavras corresponde a aproximadamente 130 horas de gravação de fala, referentes a uma média aproximada de

\footnotetext{
${ }^{13}$ Esse manual de transcrição baseia-se em algumas normas de anotação de corpus já conhecidas (cf. PRETI \& URBANO, 1986; CASTILHO \& PRETI, 1986; PAIVA, 1999).
} 
50 minutos para cada uma das amostras de $\mathrm{AC}$ e de 20 minutos para cada uma das amostras de AI. No âmbito da linguística brasileira, pode ser considerado o segundo maior banco com inquéritos de fala, estando atrás somente do Banco de Dados do projeto VARSUL (www.varsul.org.br), que reúne amostras de fala de 288 informantes de diferentes cidades dos três estados da região sul do país (GONÇALVES, 2007).

O banco de dados Iboruna foi realizado com o intuito de disponibilizar integralmente as amostras de fala da comunidade do interior paulista numa interface de fácil acesso e se encontra disponível gratuitamente no seguinte endereço eletrônico:

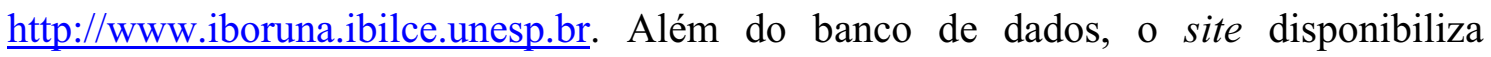
informações referentes à execução do projeto bem como as fichas sociais e os diários de campo referentes a cada amostra de fala, os quais auxiliam o pesquisador a realizar uma pesquisa sociolinguística mais detalhada.

O site oferece acesso livre a algumas amostras de AC e AI, porém, para acesso ao banco de dados integralmente, o interessado deve cadastrar-se, enviando formulário eletrônico ao administrador do site (alip@ibilce.unesp.br), mediante o qual receberá, via correio eletrônico, senha para o acesso a todo material disponível no site (GONÇALVES, 2007).

\subsection{Composição da subamostra para análise variacionista}

Para o presente estudo, selecionamos 76 amostras de narrativas de experiência pessoal (NE) extraídas do banco de dados Iboruna que representam a comunidade de fala estudada. Essa seleção baseou-se em alguns perfis sociais dos informantes, tais como: informantes do sexo feminino e masculino, pertencentes a cinco faixas etárias (7 
a 15 anos, 16 a 25 anos, 26 a 35 anos, 36 a 55 anos e mais de 55 anos) e a quatro níveis de escolaridade ( $1^{\circ} \mathrm{EF}, 2^{\circ} \mathrm{EF}, \mathrm{EM}$ e ES), e a duas faixas de renda familiar (de até 5 salários mínimos e de 6 a 10 salários mínimos). A seleção de 76 amostras de fala resulta do cruzamento dos perfis sociais acima expostos [(5 faixas etárias x 4 faixas de escolaridade $\times 2$ gêneros $=40$ informantes) $\times 2$ faixas de renda resulta em 80 informantes menos 4 informantes de 7 a 15 anos de nível superior $=76$ informantes $].{ }^{14}$

A escolha por amostras de fala justifica-se pelo fato de o fenômeno linguístico estudado ser uma regra variável de ordem morfofonológica presente na fala dos informantes da região estudada. Além disso, a teoria variacionista proposta por Labov (1972) considera os estudos da relação entre linguagem e sociedade, com o intuito de descrever e analisar os fatos linguísticos sistematizáveis. Desse modo, com o uso dessa amostra buscamos estudar a linguagem de maneira aprofundada no contexto de uso real.

A opção pela utilização do banco de dados Iboruna justifica-se pelo tipo de pesquisa sincrônica que realizamos e por ter sido composto de modo a se garantir qualidade, originalidade e coerência nas gravações e transcrições.

A seleção de apenas narrativas de experiência fundamenta-se na afirmação de Labov (1972) sobre o paradoxo do observador, em que descreve vários procedimentos para superar esse paradoxo, e um deles é tentar desviar a atenção do falante com assuntos e perguntas que possibilitem fortes emoções devido a alguma experiência do passado. Dessa forma, essas narrativas atendem melhor à nossa pesquisa sobre a comunidade de fala de São José do Rio Preto, pois elas se aproximam às falas das pessoas quando não estão sendo sistematicamente observadas, pois, ao produzir esse

\footnotetext{
${ }^{14}$ Cabe observar que é impossível o preenchimento da célula social resultante do cruzamento da faixa etária de 7 a 15 anos e do nível de escolaridade superior, o que resulta em 4 inquéritos a menos.
} 
tipo de narrativa, o informante, em geral, está menos atento à forma como produz seus enunciados, afrouxando a preocupação com a norma padrão.

A escolha de informantes do sexo feminino e masculino se deve à representação de todos os gêneros da sociedade; assim, teremos uma amostra heterogênea abarcando os falantes da comunidade de fala a ser analisada.

A escolha das faixas etárias investigadas ( 7 a 15 anos, 16 a 25 anos, 26 a 35 anos, 36 a 55 anos e mais de 55 anos) se baseia nos resultados apresentados por Mollica (1989), que, como já anunciado, mostrou que informantes equivalentes ao da nossa segunda faixa etária (16 a 25 anos) tendem a realizar o gerúndio na sua forma em “ndo", contrariando os resultados esperados, que, de acordo com Labov (1972), preveriam que falantes mais velhos preservariam mais as formas antigas, o que pode acontecer também com as pessoas mais escolarizadas, ou das camadas da população que gozam de maior prestígio social. Entretanto, essa é uma hipótese a ser testada na nossa investigação.

Além da faixa etária, consideramos o nível de escolaridade dos informantes por ser esta variável mencionada nos trabalhos de sociolinguística como fator relevante para explicar processos variáveis como o que estamos considerando. Assim, cremos que ao controlar esses dois fatores em relação ao processo que investigamos poderemos esclarecer se ambos ou se somente um deles atuam de modo relevante na aplicação da regra variável em questão.

Cabe ainda justificar que a seleção de informantes pertencentes às faixas de renda familiar mais baixas que compõem o banco de dados (até 5 salários mínimos e de 6 a 10) se baseia na hipótese de esses informantes representarem a maioria da população 
brasileira, ${ }^{15}$ portanto, a fala desses informantes pode ser considerada a mais representativa da variedade em estudo. Inicialmente, iríamos considerar a renda familiar como uma variável social, ou seja, as duas primeiras faixas de renda $\left(1^{\mathrm{a}}\right.$. renda familiar de até 5 salários mínimos; $2^{\mathrm{a}}$. renda familiar de 6 a 10 salários mínimos) do modo como estão estratificadas no Iboruna. Contudo, houve um afrouxamento desta variável durante a composição do banco de dados Iboruna para essas variantes, então, em nossa pesquisa, não consideraremos a variável social renda familiar, apesar de manter o mesmo número de 76 informantes na subamostra selecionada.

Descritas as características da subamostra de fala selecionada do banco Iboruna, passamos a apresentar as características acústicas das amostras e os procedimentos adotados no estudo.

Em um primeiro momento, havíamos previsto realizar análise acústica das formas de gerúndio por meio do programa Praat, com o intuito de verificarmos, por meio de uma análise auditiva e acústica, ${ }^{16}$ a aplicação ou não do processo. A qualidade das gravações é muito boa para uma análise auditiva, mas não é boa para uma análise acústica. Dessa forma, trabalhamos apenas com a análise de oitiva, para o conjunto de dados encontrados no corpus desta pesquisa. No entanto, não deixamos de realizar uma investigação acústica do fenômeno de redução do gerúndio a partir de um conjunto de dados controlados que gravamos com a qualidade acústica necessária para esse tipo de investigação. Na próxima subseção, tratamos da investigação acústica empreendida.

\footnotetext{
${ }^{15}$ Fonte: IBGE, Censo Demográfico 2000; Fonte: IBGE, Diretoria de Pesquisas, Coordenação de Trabalho e Rendimento, Pesquisa Nacional por Amostra de Domicílios 2005.

${ }^{16}$ A análise auditiva é a análise perceptual, de oitiva, em que ouvimos a realização do som e analisamos o segmento percebido pelo pesquisador. Já a análise acústica é aquela em que fazemos por meio do programa Praat e analisamos os parâmetros acústicos dos sons produzidos apresentados pelo programa.
} 


\subsection{Elaboração de experimento para a inspeção acústica}

Inicialmente, faz-se necessário explicitar que neste trabalho realizamos o que é denominado por inspeção acústica. Por meio da inspeção acústica, adotamos alguns procedimentos de natureza experimental para descrever acusticamente o fenômeno em estudo, ou seja, busca-se caracterizar, por meio de parâmetros acústicos o chamado fenômeno de redução da forma de gerúndio. No entanto, neste trabalho, essa investigação não ganha a profundidade de uma análise acústica propriamente dita que é ancorada em procedimentos estatísticos específicos na análise dos vários parâmetros acústicos relevantes para a caracterização fonética do fenômeno em estudo. ${ }^{17}$ Desse modo, a inspeção acústica, neste trabalho, limita-se a descrever parâmetros acústicos que se mostram importantes (porém sem confirmação da relevância estatística) para fundamentar a percepção auditiva do apagamento da oclusiva alveolar /d/ na forma de gerúndio.

Assim, para a inspeção acústica, elaboramos um experimento. Foram informantes deste experimento três mulheres com idade entre 24 e 25 anos com nível superior e naturais de São José do Rio Preto. ${ }^{18}$ As participantes deste estudo apresentavam bom estado de saúde e no momento da gravação não apresentaram alterações vocais. Para elaborar o material dessa pesquisa, inicialmente foi feito um mapeamento das formas verbais que, nos dados de fala do Iboruna, haviam sofrido, a partir de uma análise de oitiva, a redução do gerúndio. Em seguida, construiu-se uma

\footnotetext{
${ }^{17}$ Uma análise acústica do fenômeno de redução de gerúndio é feito por Oliveira \& Marin (2005).

18 A escolha de informantes de sexo feminino e de nível superior baseou-se em Labov (1972), que argumenta que as mulheres prestigiam a norma padrão e que os falares das pessoas com escolaridade de nível superior caracterizam a norma culta da língua. No entanto, já há estudos sociolinguísticos que apontam questionamentos sobre essa premissa, Gonçalves (2008) investigou que para fenômenos fonológicos os resultados apontam para uma correlação segura com o fator nível de escolaridade, porém, para fenômenos sintáticos essa mesma sistematicidade não se verifica, pois neste caso a relevância fica por conta de fatores estruturais.
} 
tabela com a porcentagem desses verbos que apresentavam variação e, a partir desse primeiro resultado, montamos um experimento, como demonstrado no Quadro 1.

Quadro 1. Variáveis linguísticas estabelecidas para o experimento

\begin{tabular}{|c|c|c|}
\hline Variáveis sintáticas & Variáveis morfológicas & Exemplos \\
\hline $\begin{array}{l}\text { 1. Perífrase: estar + "gerúndio" } \\
\text { (P) }\end{array}$ & $\begin{array}{c}1^{\text {a }} \text { conjugação } \\
\text { Regular } \\
\text { Irregular } \\
2^{\text {a conjugação }} \\
\text { Regular } \\
\text { Irregular } \\
3^{\text {a }} \text { conjugação } \\
\text { Regular } \\
\text { Irregular }\end{array}$ & $\begin{array}{l}\text { Pedro está brincando pela rua. } \\
\text { Maria está dando um jantar. } \\
\text { Paulo está morrendo de saudade. } \\
\text { Mário está perdendo o controle. } \\
\text { Dara está saindo com César. } \\
\text { Talita está indo ao dentista. }\end{array}$ \\
\hline $\begin{array}{l}\text { 2. Oração reduzida de gerúndio } \\
\text { (ORG) }\end{array}$ & 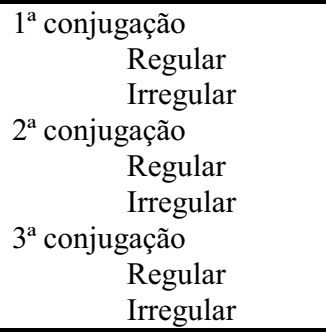 & $\begin{array}{l}\text { Pedro saiu brincando pela rua. } \\
\text { Maria acabou o dia dando um jantar. } \\
\text { Paulo ficou em casa morrendo de saudade. } \\
\text { Mário saiu perdendo o controle. } \\
\text { Dara passou meses saindo com César. } \\
\text { Talita mostrou-se forte indo ao dentista. }\end{array}$ \\
\hline 3. Frase foco Reduzida (FFR) & 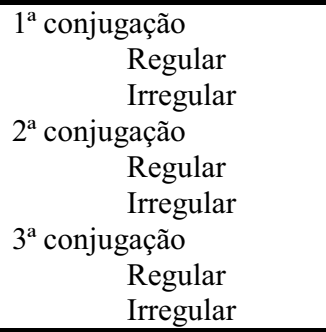 & $\begin{array}{l}\text { Diga "brincano" para ele. } \\
\text { Diga "dano" para ele. } \\
\text { Diga "morreno" para ele. } \\
\text { Diga "perdeno" para ele. } \\
\text { Diga "saino" para ele. } \\
\text { Diga "ino" para ele. }\end{array}$ \\
\hline 4. Frase foco $(\mathrm{FF})$ & 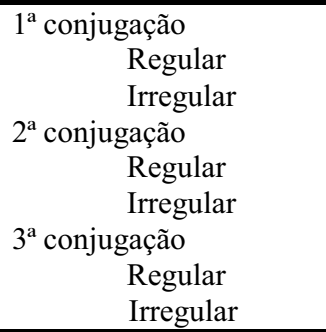 & $\begin{array}{l}\text { Diga "brincando" para ele. } \\
\text { Diga "dando" para ele. } \\
\text { Diga "morrendo" para ele. } \\
\text { Diga "perdendo" para ele. } \\
\text { Diga "saindo" para ele. } \\
\text { Diga "indo" para ele. }\end{array}$ \\
\hline
\end{tabular}

As 24 sentenças que se encontram no Quadro 1 são as que estão presentes no experimento elaborado. Assim, foram controladas três variáveis: (i) conjugação verbal $\left(1^{\mathrm{a}}, 2^{\mathrm{a}}, 3^{\mathrm{a}}\right)$; (ii) regularidade/irregularidade morfológica do verbo (REG/nãoREG); ${ }^{19}$ (iii) estrutura sintática (Perífrase/ Oração reduzida/Frase foco). Essas sentenças foram

${ }^{19}$ O controle das variáveis (i) e (ii) foi feito a fim de confirmar a hipótese de que as diferenças paradigmáticas e as (i)regularidades morfológicas do verbo não afetam o fenômeno de redução do gerúndio. 
repetidas três vezes pelas três informantes, o que resultou em 216 ocorrências de sentenças com as formas de gerúndio, resultante do produto entre 24 sentenças, 3 repetições e 3 informantes.

Desse modo, a elaboração do experimento levou em conta os seguintes fatores para construção das frases:

1. Verbos que apresentaram variação em /ndo/ e /no/ no corpus Iboruna;

2. Verbos com maior porcentagem de redução no corpus Iboruna: dar; brincar; perder; morrer; ir e sair. Exclui-se desse critério o verbo sair, que apresentou 37.5\% para ocorrência de /no/. Porém, foi preciso incluir esse verbo no experimento porque os outros verbos regulares da $3^{\mathrm{a}}$ conjugação não apresentaram variação, isto é, às vezes, apresentaram 100\% de redução /no/, outras vezes, $100 \%$ de não redução /ndo/;

3. Duas formas verbais de cada conjugação, sendo um regular e um irregular;

4. Dois contextos morfossintáticos: a) perífrase de verbo principal + “-ndo" (P) e b) orações reduzidas de gerúndio (ORG).

5. Dois tipos de frases: a) frase foco com a forma reduzida (FFR) e b) frase foco com a forma não reduzida (FF): Diga “...” para ele, sendo uma frase com a forma reduzida "-no" (FFR) e outra com a forma não-reduzida "-ndo". 20

Para a gravação das sentenças do experimento, organizamos-as aleatoriamente em relação às variáveis linguísticas para que as informantes não intuíssem qual era o foco de nossa pesquisa e para que os nossos resultados não fossem enviesados. ${ }^{21}$ No momento da gravação, foi pedido que o participante lesse cada sentença em tom e

\footnotetext{
${ }^{20}$ Os contextos de frase foco foram incluídos na metodologia para isolar o segmento a ser analisado na análise acústica, o uso dessas frases-veículo é um procedimento comum nas análises acústicas, pois esses enunciados isolam a 'palavra alvo' para a realização da análise estatística.

21 Encontra-se, no Apêndice A, o experimento que as informantes produziram para a investigação acústica.
} 
velocidade confortável, ou seja, em tom habitual de sua fala e, em seguida, repetisse por três vezes a mesma sentença sem olhar para o texto. ${ }^{22}$ Colocamos um microfone (microfone unidirecional headset 'Leader ship') próximo à boca do participante e gravamos a voz no programa do computador (PRAAT-versão 5.0.09) com o auxílio de um notebook (marca Acer com placa de som interna). Antes da gravação, fizemos um teste para que o informante ajustasse o volume de voz para gravação. Todos esses procedimentos foram realizados com a participante na presença da pesquisadora responsável e de uma colaboradora.

A realização desse experimento justifica-se por procurarmos responder às seguintes questões: (i) A redução de gerúndio ocorre nas duas estruturas sintáticas controladas, independentemente da conjugação $\left(1^{\mathrm{a}}, 2^{\mathrm{a}}, 3^{\mathrm{a}}\right)$ e independentemente de $\mathrm{o}$ verbo ser regular ou irregular? (ii) Com que porcentagem o processo de redução ocorre em cada estrutura sintática? Se houver diferença de porcentagem de aplicação da regra, tal diferença poderá estar relacionada à diferença de estrutura sintática?

Nossas expectativas são: 1) não haver diferença relevante entre as diferentes conjugações; 2) não haver diferença relevante entre verbos regulares/irregulares; 3) haver alguma diferença relevante entre perífrase verbal e oração reduzida de gerúndio. Nossas hipóteses são: 1) a redução de gerúndio não é influenciada pela: (a) conjugação a qual pertence o verbo, e (b) regularidade ou irregularidade do verbo; 2) a redução depende da estrutura sintática em que a forma de gerúndio ocorre, uma vez que 'estar +

\footnotetext{
22 Labov (1972, p.247-248) argumenta que a leitura de textos foi usada para estudar variações fonológicas. Estudos como os de Levine \& Crockett (1966) e Anshen (1969) aproximam-se do experimento realizado em nossa pesquisa, pois eles usaram métodos em que construíram frases que continha as variáveis pesquisadas encaixadas e, em outros pontos, nas mesmas frases, foram inseridas lacunas para a pessoa preencher com itens lexicais enquanto lia, desviando sua atenção das variáveis em estudo. Tais estudos revelaram que ao usar frases na pesquisa, o informante fica menos preocupado com a forma gramatical do que ao fazer leitura de palavras isoladas e, assim, aproxima-se da fala informal.
} 
ndo' funciona como uma unidade morfossintática mais "integrada" do que a estrutura de 'verbo principal' + 'verbo de oração gerundiva'.

Após as gravações das amostras de fala dos informantes, foi feita (i) a transcrição fonética das formas de gerúndio das 216 sentenças, por meio de uma análise perceptivo-auditiva; (ii) a segmentação dos dados por meio do programa Praat para analisar os sinais acústicos; (iii) a análise qualitativa dos dados; (iv) a comparação entre os resultados da percepção auditiva e da análise acústica.

Para inspecionar o sinal acústico, utilizamos a medição dos parâmetros caracterizadores da oclusiva alveolar [d] em contexto de morfema de gerúndio: a closura, o burst, a transição formântica, obtidos por meio de dados descritivos fornecidos pelo programa Praat, e a duração relativa. Este último parâmetro é utilizado para obtermos a proporção que a oclusiva ocupa no interior da forma de gerúndio, apontando assim evidências para identificarmos o apagamento ou a ocorrência de /d/.

Para finalizar, comparamos os resultados da inspeção acústica de natureza experimental e da análise variacionista do corpus que investigamos, para examinarmos em que medida há ou não concordância entre o dado percebido e o dado produzido. Esse tipo de relação tem desencadeado um debate muito caloroso na área dos estudos fonéticos e fonológicos, pois, como demonstramos no capítulo teórico, para alguns autores, nem sempre o som percebido corresponde ao som que foi produzido (HOUSER, 1957; GAY, 1970; WINITZ et al., 1972; OHALA, 1979). Além disso, a partir das repetições dos enunciados do experimento acústico, a pesquisa de natureza acústica colabora com a análise variacionista, de modo a auxiliar com maior precisão a distinção fonológica da variável linguística e situar onde a regra variável está operando, pois essas repetições desvendam as regras gramaticais subjacentes dos falantes, segundo Labov (1972). 


\subsection{Variáveis operacionais}

Muitos estudos como os de Mollica (1989) e Martins (2001) entre outros, já consideraram como regra variável o fenômeno de apagamento do /d/ em morfema de gerúndio, em que o falante, ao realizar o gerúndio, alterna entre a forma reduzida [no] e forma não-reduzida [ndo]. O conceito de regra variável adotado na presente pesquisa é aquele de que a regra variável é uma afirmação da probabilidade de que um falante irá aplicar o mapeamento de algumas regras mais abstratas em um conjunto menos abstrato. Assim, o falante exibe seu conhecimento sobre o sufixo de gerúndio, reduzindo mais esse morfema do que outros, porém tudo o que o ouvinte tem de saber é se a forma /no/ é opcional ou não, já que ele interpreta cada sinal de gerúndio à medida que o recebe e, a partir disso, passa a fazer uma avaliação para aceitar, interpretar ou rejeitar essa regra, por meio de restrições variáveis (cf. LABOV, 1972).

Para explicar uma regra variável, muitos aspectos linguísticos e extralinguísticos podem ser observados a afetar a probabilidade de aplicação da regra, o que demandaria uma quantidade de dados imensa para calcular a probabilidade de aplicação. Cedergren \& Sankoff (1972), baseados no modelo aditivo apresentado por Labov (1969) em seu estudo com a contração e o apagamento da cópula no inglês, propuseram um novo modelo estatístico multiplicativo que quantifica as restrições variáveis como probabilidades subjacentes. Esse modelo visa a uma interpretação da natureza do componente probabilístico de competência linguística. A partir do método estatístico de probabilidade, é possível confirmar ou rejeitar a hipótese de independência de condicionamentos variáveis em qualquer instância particular e, assim, oferecer dados fundamentais para validar a operação linguística básica de composição de esquemas de regras. 
Assim, em nossa pesquisa, além de um estudo de natureza fonológica, realizamos também um estudo quantitativo embasado pela Sociolinguística Variacionista (LABOV, 1972), fazendo uso do pacote estatístico Goldvarb para manipular os dados coletados. A pesquisa quantitativa justifica-se na asserção de que a escolha do falante entre uma ou outra forma obedece a um padrão sistemático regulado por regras variáveis que "expressam a covariação entre elementos do ambiente linguístico e do contexto social" (cf. BRESCANCINI, 2002, p. 15). Esse tipo de pesquisa também é relevante por orientar o pesquisador na explicação e na análise de uma grande quantidade de dados com o intuito de procurar hipóteses que justificam os resultados oferecidos pelo programa estatístico.

Para a análise quantitativa, selecionamos na subamostra as ocorrências que apresentavam forma nominal de gerúndio e consideramos como variável dependente binária a aplicação (5a) e a não-aplicação (5b) do processo de redução do gerúndio:

(5) a. eu ficava conversan (d)o o tempo todo

[AC-014:NE:L.75]

b. ai professora tô entendendo tudo agora

[AC-014:NE:L.73]

\subsubsection{Variáveis linguísticas}

Apresentamos nesta subseção as variáveis linguísticas organizadas em grupos.

\section{Verbo V1 da perífrase gerundiva}

A análise do grupo de fatores que controla o tipo de $V 1$ pretende verificar se o fato de o V1 ser um auxiliar mais gramaticalizado favorece a aplicação da redução de 
gerúndio; logo, descobrir-se-á qual tipo de $V 1$ condiciona ou não a aplicação da regra

(cf. LOBATO, 1975).

Os V1's encontrados no corpus encontram-se em (6)

(6)

a. Estar

e:: aí eu num tava conseguin(d)o estudá(r) muito bem lá na casa dela...

b. Ficar

[AC-006:NE:L.7]

mas assim ele fica:: brincan::(d)o com brincade(i)ra que eu num:: que eu num gosto...

[AC-006:NE:L.66]

c. $\quad$ Ir

ai meu tio pegô(u) foi lá pegô(u) uma cade(i)ra... me colocô(u) e:: e ele $\boldsymbol{i} \boldsymbol{a}$ puxan $(d) o$ meu/ minha perna e meu pai... ia:.... empurran(d)o a cade(i)ra...

d. Continuar

[AC-014:NE:L28-29]

eu aqui em Mirassol e ele lá em São Paulo... a gente ia continuá(r) namoran(d)o... ia continuá(r) usan(d)o alian::ça... um respeitando o o(u)::tro...

e. Acabar

[AC-022:NE:L.60-62]

meu pai $\boldsymbol{a c a b} \hat{\boldsymbol{o}}(\boldsymbol{u})$ in $(d) o$ embora de ca::sa...

f. Vir

[AC-038:NE:L.21]

já há muito tempo que a coisa vinha se arrastando né...

g. $\quad$ Ter

[AC-110:NE:L.40]

se ela tivesse vindo naquele período

[AC-128:NE:L.48-49]

h. Viver

eles queriam sê(r) machão queria sempre sê(r) o mais forte então ele vivia insultan $(d)_{o}$ alguém pra/ pa arrumá(r) um encrenca... e nesse dia ele (a)cabô(u) levan(d)o a pior comigo

[AC-93:NE:L.30]

Encontrado os verbos auxiliares presente no corpus, os classificamos em auxiliares propriamente ditos e auxiliantes, segundo os critérios de auxiliaridade propostos por Lobato (1975). Os auxiliares propriamente ditos pertencem ao grupo de verbos que satisfaz a todos os testes de critérios de auxiliaridade. ${ }^{23}$ Segundo a autora, a

\footnotetext{
${ }^{23}$ Segundo Lobato (1975), dentre vários critérios de auxiliaridade, os principais são: oposição entre a forma marcada e não-marcada; unidade semântica (um só sujeito para os dois verbos); carência de
} 
expressão "verbos auxiliares tradicionais" só se aplica aos verbos ser, estar, ter e haver; já as outras formas são consideradas auxiliantes, pois, são formas que constituem operadores marcando: a intenção (tentar, planejar, etc.); o aspecto (ficar, vir, ir, viver, acabar de, começar $a$, etc.); o resultado (chegar $a$, vir $a$, etc.) entre outros.

\section{Estrutura sintática}

Inserimos esse grupo de fatores para detectar se há algum ambiente sintático mais propício à redução do gerúndio. Assim, propomos a investigação das seguintes estruturas sintáticas possíveis para a realização do gerúndio:

a) Perífrase constituída de "verbo (V1) + gerúndio (V‘ndo’)":

(7) ele tava baten(d)o num molequinho pequenininho... [AC-005:NE:L.38]

b) Orações reduzidas de gerúndio:

(8) pa escapá(r) de mim eu dei um murrão nele daí ele saiu choran(d)o po banhe::(i)ro

[AC-005:NE:L.51]

c) Contexto ambíguo entre perífrase e oração reduzida de gerúndio:

(9) Eu desci lá... fui lá andan(d)o cheguei lá minha avó tinha visto o corte

[AC-037:NE:L.76]

d) Justaposição à perífrase V1 + "ndo":

(10) Eles estavam discutin(d)o fazen(d)o o maior pampeiro.

[AC-015:NE:L.190]

imperativo; impossibilidade de construções completivas; incidência de um circunstante temporal; apassivação; extensão combinatória; negativização e pronominalização. Para maiores detalhes desses critérios, sugerimos a leitura de capítulo intitulado Os verbos auxiliares em Português contemporâneo: critérios de auxiliaridade de Lobato (1975). 
e) Expressões cristalizadas (marcador discursivo):

(11) Ele falou -"num acredito"- e eu falei - tá ven(d)o?... se eu tivesse falado pra você naquela época você não acreditaria

[AC-063:NE:L.98]

Em nossa hipótese, esses fatores podem determinar de maneira precisa o contexto condicionador da aplicação da regra de redução do morfema de gerúndio, abarcando também as ocorrências cuja classificação da estrutura é ambígua (cf. LEMLE, 1984; LOBATO, 1975; BERTUCCI, 2007, BRAGA \& CORIOLANO, 2007). Assim, juntamente com o grupo de fatores relacionado ao $V 1$ da perífrase, podemos verificar se os casos duvidosos estão relacionados aos verbos que ainda estejam em processo de gramaticalização.

\section{Material interveniente entre V1 e V'ndo}

Nas perífrases, pode ocorrer material interveniente entre $V 1$ e $V$ "ndo" com uma sílaba (12a), duas sílabas (12b), três ou mais sílabas (12c) ou nenhuma (12d).

a. $\quad$ á é:: foi eu... minha mãe é:: minha tia D. a V.... minha/ minha o(u)tra ti::a... que tá me entrevistan(d)o agora...

[AC-037:NE:L.10]

b. - - - "na/ nossa parece que tá até voan(d)o o ônibus...

[AC-109:NE:L.140]

c. $\quad$ Eu tava bem $\operatorname{diz} \hat{\boldsymbol{e}}(\boldsymbol{r}) \operatorname{toman}(d)_{o}$ uma decisão na vida;

[AC-029:NE:L.47]

d. aí ela pegô(u) e parô(u) assim falô(u) assim -"óh se cê tá choran(d)o é porque cê fez coisa errada né?"-...

[AC-045:NE:L.82]

A inserção do grupo de fatores material interveniente entre V1 e V"ndo" justifica-se pela hipótese sintática de que, quando há material interveniente entre o 
auxiliar e o auxiliado, isso enfraquece a unidade semântica da perífrase. Além disso, a partir desse grupo, pode-se verificar a hipótese fonológica de que quanto mais distante o V1 do verbo na forma de gerúndio, menor seria a aplicação da regra de apagamento do /d/ do morfema de gerúndio nas perífrases.

\subsubsection{Variáveis extralinguísticas}

São três as variáveis extralinguísticas que investigamos nesta pesquisa.

\section{Gênero: Masculino e Feminino}

A escolha de informantes do sexo feminino e masculino se deve à representação de todos os gêneros da sociedade. Além disso, é comum nas pesquisas sociolinguísticas que as mulheres sejam mais sensíveis do que os homens às formas de prestígio. Como o apagamento do /d/ em morfema de gerúndio, na região de São José do Rio Preto, é uma variante não-padrão, a título de hipótese, é possível considerar que as mulheres sejam mais sensíveis que os homens ao prestígio da forma padrão, e, portanto, apresentem mais incidência dessa variante em suas elocuções.

\section{Idade: 7 a 15 anos, 16 a 25 anos, 26 a 35 anos, 36 a 55 anos e mais de 55}

anos

Nos resultados apresentados por Mollica (1989) para os dados do Rio de Janeiro, informantes equivalentes ao da faixa etária de 16 a 25 anos tendem mais a realizar o gerúndio na sua forma em "-ndo", contrariando os resultados esperados, que, de acordo com Labov (1972), preveriam que os falantes mais velhos preservariam mais 
frequentemente as variantes mais conservadoras, "-ndo", o que pode acontecer também com as pessoas mais escolarizadas, ou que gozam de maior prestígio social.

Ao analisarmos a realização do gerúndio na fala de informantes de gênero feminino da região de São José do Rio Preto (SP) em nível de iniciação científica, verificamos que, diferentemente dos resultados de Mollica (1989), os informantes mais jovens são os que mais favorecem a aplicação do fenômeno de redução do gerúndio.

Dessa maneira, a escolha das faixas etárias ( 7 a 15 anos, 16 a 25 anos, 26 a 35 anos, 36 a 55 anos e mais de 55 anos) se baseia na hipótese de que a aplicação da regra aqui estudada é condicionada pela faixa etária do informante.

\section{superior \\ 3. Escolaridade: $1^{\circ}$ ciclo do $\mathrm{EF}, 2^{\circ}$ ciclo do EF, ensino médio e ensino} Além da faixa etária, os níveis de escolaridade $\left(1^{\circ}\right.$ ciclo do ensino fundamental, $2^{\circ}$ ciclo do ensino fundamental, ensino médio e ensino superior) são mencionados nos trabalhos de sociolinguística como fator relevante para explicar processos variáveis como o que estamos considerando. O sistema escolar é o lugar, por excelência, do cultivo da variedade padrão, que está presente na gramática escolar; a variedade não-padrão é observada em contextos do cotidiano e não está presente no âmbito dos livros escolares. Em função disso, é possível esperar uma relação proporcionalmente direta entre aumento de escolaridade e taxa do uso da variante padrão. Assim, ao controlar os fatores faixa etária e escolaridade em relação ao processo que investigamos, podemos esclarecer se ambos ou se somente um deles atua de modo significativo na aplicação da regra variável em questão. 


\subsection{Passos metodológicos da quantificação e da análise variacionista}

Após a seleção dos 76 inquéritos de fala da AC/Iboruna, identificamos nas transcrições ortográficas de narrativas de experiência todas as ocorrências que apresentaram forma nominal de gerúndio, juntamente com os contextos sintáticos. Organizamos as ocorrências em uma tabela. ${ }^{24}$

Levantados os dados, passamos à transcrição fonética de base perceptual por meio da qual identificamos a aplicação ou a não-aplicação do fenômeno de redução de gerúndio.

Para a análise quantitativa, o processamento de dados foi feito eletronicamente, empregando-se o programa GoldVarb, criado com a finalidade específica de tratamento de fenômenos variáveis. O programa extraiu as frequências e os pesos relativos dos fatores linguísticos e sociais relevantes na aplicação da regra variável.

À fase precedente à quantificação dos dados foi feita uma leitura qualitativa dos mesmos que permitiu compreender e explicar os resultados estatísticos fornecidos pelo programa, o que será apresentado na próxima seção.

\subsection{Resumo}

Nesta seção, apresentamos o conceito de comunidade de fala que adotamos para esta pesquisa; caracterizamos a comunidade de São José do Rio Preto e o banco de dados Iboruna, além disso, descrevemos como está composta a subamostra pesquisada e os procedimentos metodológicos da quantificação e da análise dos dados. Dessa

\footnotetext{
${ }^{24}$ Encontram-se, no Apêndice B, as tabelas de ocorrências.
} 
maneira, procuramos explicitar o desenvolvimento da pesquisa, apresentando as etapas metodológicas que norteiam este trabalho.

Devido ao fato de o fenômeno se caracterizar como regra variável, nós lançamos mão da metodologia sociolinguística variacionista, apresentando os grupos de restrições variáveis, linguísticos e extralingüísticos, selecionadas para as nossas análises. Assim, apresentamos todos os grupos de fatores controlados para a análise da variável dependente, em que a ausência do [d] no morfema de gerúndio caracteriza a aplicação da regra e a presença do [d] no morfema de gerúndio assinala a não-aplicação. 


\section{ANÁLISE DO APAGAMENTO DO [d] EM MORFEMA DE GERÚNDIO}

Nesta seção, apresentamos as análises dos resultados do fenômeno de apagamento do [d] em morfema de gerúndio: na subseção (3.1), apresentamos uma análise acústica do experimento produzido, cuja metodologia descrevemos na seção (2); na subseção (3.2), analisamos a aplicação do fenômeno sob a ótica da teoria da Fonologia Lexical; na subseção (3.3), realizamos uma análise da regra variável sob a ótica da teoria Sociolinguística Variacionista.

\subsection{Inspeção acústica do apagamento do [d] em morfema de gerúndio}

A partir da gravação do experimento para constituir a amostra de fala para a inspeção acústica, foram desenvolvidas as seguintes etapas: (i) a transcrição fonética das 216 sentenças para identificar o processo fonológico de redução do morfema de gerúndio, por meio de uma análise perceptivo-auditivo; (ii) a segmentação dos dados no programa Praat para analisar o sinal acústico; (iii) a análise qualitativa dos dados; (iv) um quadro comparativo entre a percepção auditiva e o sinal acústico.

O critério que adotamos para realizar a avaliação perceptual foi a indicação da presença ou da ausência do /d/ quando morfema de gerúndio. A presença é caracterizada quando percebemos, de oitiva, a realização do segmento em contexto de gerúndio, como, por exemplo, em sain $[d] o$, codificando essa variante com o número " 0 ”, para indicar o não apagamento de /d/; a ausência é caracterizada quando não é possível, de oitiva, detectar a realização do segmento /d/ em contexto de gerúndio, como, por 
exemplo, em sain[Ø]o, codificando essa variante com o número "1", para indicar o apagamento do segmento /d/.

$\mathrm{Na}$ inspeção acústica, os critérios adotados para a análise foram: a quantificação da closura, burst, transição formântica e duração relativa. Esses parâmetros dão pistas para caracterizar a presença da consoante $/ \mathrm{d} /$, segundo Kent \& Read (1992) e Russo \& Behlau (1993).

No experimento, ao compararmos a análise perceptual e a acústica, observamos que a divergência se deve a sentenças que apresentaram as estruturas Perífrase e Frase foco. No quadro abaixo são mostradas as ocorrências em que notamos divergência entre as análises perceptual e acústica.

Quadro 2. Comparação entre análise perceptual e análise acústica, por aplicação (1) ou não aplicação (0) do apagamento da consoante /d/: Contexto Perifrase

\begin{tabular}{|l|l|l|l|l|l|l|}
\hline & \multicolumn{7}{|c|}{ Perífrase } \\
\hline \multirow{7}{*}{ Análises } & \multicolumn{7}{|c|}{ Perceptiva } & \multicolumn{3}{|c|}{ Acústica } \\
\cline { 2 - 7 } Informantes & \multicolumn{7}{|c|}{ Repetições } \\
\cline { 2 - 7 } & 1 & 2 & 3 & 1 & 2 & 3 \\
\hline BRINCAR & 0 & 0 & 0 & 1 & 0 & 0 \\
\hline inf. 2 & 0 & 1 & 1 & 1 & 1 \\
\hline inf. 3 & 0 & 0 & 1 & 0 & 1 & 1 \\
\hline MORRER & 0 & 0 & 0 & 0 & 1 & 0 \\
\hline inf. 2 & 1 & 0 & 1 & 1 & 1 & 1 \\
\hline PERDER &
\end{tabular}

Quadro 3. Comparação entre análise perceptual e análise acústica, por aplicação (1) ou não aplicação (0) do apagamento da consoante /d/: Contexto Frase Foco

\begin{tabular}{|l|l|l|l|l|l|l|}
\hline \multicolumn{7}{|c|}{ Frase foco } \\
\hline \multirow{7}{*}{ Análises } & \multicolumn{7}{|c|}{ Perceptiva } & \multicolumn{1}{|c|}{ Acústica } \\
\cline { 2 - 7 } & \multicolumn{7}{|c|}{ Repetiçes } \\
\cline { 2 - 7 } & 1 & 2 & 3 & 1 & 2 & 3 \\
\hline DAR & 0 & 0 & 0 & 1 & 1 & 1 \\
\hline inf. 3 & 0 & 0 & 0 & 1 & 0 & 0 \\
\hline BRINCAR R & 1 & 1 & 1 & 1 & 1 & 0 \\
\hline inf. 2 & 1 & 0 & 0 & 1 & 1 & 0 \\
\hline MORRER & 0 & 0 & 0 & 1 & 0 & 0 \\
\hline inf. 3
\end{tabular}

Nos Quadros 2 e 3, no que se refere à ausência ou presença do [d] em morfema de gerúndio, apontamos apenas as 12 ocorrências que apresentaram divergências (célula sombreada nos Quadros) na amostra de 216 ocorrências. Nesses quadros, observamos a comparação da análise perceptiva e acústica das três repetições (1, 2 e 3) produzidas por 
dois informantes (inf. 2 e inf. 3) ao lerem as frases do experimento acústico que apresentavam estrutura de Perífrase, como Pedro está brincando pela rua, e de Frase Foco, como Diga "brincando" para ele, formadas com os verbos dar, brincar, morrer, perder e sair. Pode-se observar ainda nos Quadros 2 e 3 que a maioria das divergências refere-se à não-aplicação do apagamento, na análise perceptual, em que reconhecemos, por exemplo, a realização 'brinca[ndo]', mas que a análise acústica revelou, na verdade, tratar-se de variante com o apagamento, como, por exemplo, 'brinca[no]'. Já, na análise perceptual da Frase Foco com o verbo morrer, a forma de gerúndio foi percebida como tendo sofrido o processo de apagamento, mas, a análise acústica não confirmou a ausência de /d/, e, portanto, não se confirmando a redução do morfema de gerúndio.

As considerações de Labov (1972) sobre a variação linguística apontam que não existe falante de estilo único. Assim, observamos na análise acústica que um mesmo informante alterna a velocidade de fala ao fazer a repetição das frases do experimento. Além disso, resgatando a discussão de Ohala (1979), é possível dizer que, a partir da acústica, também podemos descrever os fenômenos, uma vez que nem sempre o que ouvimos é exatamente aquilo que produzimos, como pudemos notar na análise comparativa.

Deste modo, acreditamos que há duas explicações possíveis para o fato de ouvirmos um segmento na análise perceptual que não se realiza na análise acústica: (i) talvez o ouvido tenha percebido algum parâmetro caracterizador da consoante [d], porém nem todos os parâmetros que caracterizam essa consoante na análise acústica tenham sido produzidos, ou (ii) seria devido ao grande envolvimento com os dados. ${ }^{25}$

\footnotetext{
${ }^{25}$ A contradição entre a análise perceptiva e acústica não compromete o trabalho de percepção aplicado aos dados do Iboruna, feito de oitiva, pois, o que fizemos aqui foi apenas uma inspeção acústica para verificar o sinal acústico da consoante /d/, uma análise acústica demandaria uma gama de análises
} 
Assumindo a primeira hipótese, passamos a tratar, na Tabela 3, os parâmetros acústicos caracterizadores da consoante /d/ aqui estudada.

Tabela 3. Parâmetros acústicos da oclusiva [d] do verbo morrendo realizado pela informante 3 na última repetição (3)

\begin{tabular}{c|c|c|c|c}
\hline \multicolumn{5}{c}{ Frase Foco } \\
\hline Repetição & Closura (ms) & Burst $(\mathbf{m s})$ & F1 (Hz) & F2 (Hz) \\
\hline $\mathbf{3}$ & 18 & 9 & 449 & 1556 \\
\hline
\end{tabular}

As medidas apresentadas na Tabela 3 mostram que a consoante [d] na terceira repetição do informante 3 , mesmo com um burst dentro dos parâmetros definidos pela literatura, de 5 a 40ms, apresenta uma closura de $18 \mathrm{~ms}$, o que indica uma perda de sua qualidade da consoante /d/, já que na literatura, esse parâmetro seria de 50 a $100 \mathrm{~ms}^{26}$

Observe a Tabela 4 que demonstra a frequência de aplicação e não-aplicação em cada uma das análises:

Tabela 4. Frequência de aplicação e não-aplicação do apagamento da consoante /d/ nas análises realizadas $^{27}$

\begin{tabular}{l|c|c}
\hline \multirow{2}{*}{ Análises } & \multicolumn{2}{|c}{ Frequência (\%) } \\
\cline { 2 - 3 } Apagamento do /d/ & Perceptiva & Acústica \\
\hline Não-aplicação & $110(68 \%)$ & $100(62 \%)$ \\
Aplicação & $52(32 \%)$ & $62(38 \%)$ \\
\hline Total & \multicolumn{2}{|c}{$\mathbf{1 6 2 ( 1 0 0 \% )}$} \\
\hline
\end{tabular}

estatísticas que não é o foco do nosso trabalho. O que procuramos mostrar é que o nosso ouvido percebe segmentos que não estão no sinal acústico ou que estão lá, mas o ouvinte não percebe, logo, verifica-se que há uma gradação da noção de gesto articulatório (cf. ALBANO, 2001). Assim, pode-se notar que os lugares contraditórios são poucos, pois sabendo que há gradação, como ouvinte, conseguimos categorizar fonologicamente a presença ou a ausência da consoante /d/. Uma reflexão sobre essa percepção/produção será tema de trabalhos futuros.

${ }^{26}$ A perda da qualidade da consoante possivelmente é o que motiva a percepção de oitiva da "redução de gerúndio". Uma pesquisa sobre o que é produzido e o que é percebido poderá vir a confirmar esta possível relação, fundamentando, possivelmente, a relação entre produção do gesto articulatório (de natureza gradual) e a percepção, discretizada em segmentos (de natureza categórica).

${ }^{27} \mathrm{Na}$ Tabela 4, o total das ocorrências é de 162 porque excluímos, para essa análise comparativa, as sentenças que caracterizam a Frase Foco Reduzida, pois as colocamos no experimento apenas para comparar com os dados que não tivessem redução, caso nenhuma das informantes realizasse o apagamento do [d] em contexto de gerúndio. 
$\mathrm{Na}$ Tabela 4, notamos que o apagamento da consoante /d/, quando em morfema de gerúndio, em termos gerais, tem uma aplicação relativamente baixa (38\%), pois não atinge nem $50 \%$ do total das ocorrências, e a comparação realizada entre as análises perceptual e a acústica mostra que se diferencia muito pouco uma da outra, visto que a análise perceptiva apresenta 32\% de aplicação e a análise acústica 38\%, logo, tendem a apresentar uma aproximação.

Passamos, a seguir, a tratar dos parâmetros acústicos investigados na inspeção acústica dos dados.

\subsubsection{Análises dos parâmetros acústicos}

Quando observamos a closura, tempo de bloqueio caracterizado como baixo que dá pista de que seja uma oclusiva sonora devido à energia de baixa frequência, notamos que esse fato é fundamental para a classificação do segmento /d/, quando em morfema de gerúndio, pois sempre que ocorre seu apagamento, essa closura não aparece no espectograma, apresentando apenas as características acústicas do segmento nasal /n/, como, por exemplo, o murmúrio nasal que são regiões de grande redução de energia. Em nossos dados, a média dos resultados do parâmetro acústico obtida em relação aos fatores linguísticos analisados pode ser vista na Tabela 5. 
Tabela 5. Valores médios da Closura da oclusiva /d/ em contexto de gerúndio nas Perífrases (P), Orações Reduzidas de Gerúndio (ORG), Frases Foco (FF) em Milissegundos (ms).

\begin{tabular}{|c|c|c|c|c|}
\hline \multicolumn{5}{|c|}{ Closura (ms) } \\
\hline Verbo & $\mathbf{P}$ & ORG & FF & $\begin{array}{l}\text { Média da } \\
\text { closura de } \\
\text { /d/ } /\end{array}$ \\
\hline Dando & 59 & 64 & 68 & 63 \\
\hline Brincando & 67 & 38 & 43 & 49 \\
\hline Perdendo & 71 & 51 & 38 & 53 \\
\hline Morrendo & 49 & 41 & 44 & 45 \\
\hline Indo & 38 & 50 & 39 & 42 \\
\hline Saindo & 42 & 25 & 28 & 31 \\
\hline
\end{tabular}

A observação desse parâmetro acústico mostra, expressivamente, que a maioria dos verbos analisados apresenta baixo tempo de duração da closura em relação ao tempo médio da consoante plena, que está entre 50-100ms de duração, dando pistas de que a consoante /d/ na variedade pesquisada, quando em contexto de gerúndio, tem uma duração de tempo de closura entre $30-70 \mathrm{~ms}$, fenômeno que causa perda da qualidade dessa consoante oclusiva alveolar sonora.

No que se refere à verificação do burst, explosão momentânea próxima da vogal, notamos que todas as frequências analisadas que deram pistas sobre esse parâmetro apresentaram uma medida dentro dos valores médios dados pela literatura, que está entre $10-40 \mathrm{~ms}^{28}$ A Tabela 6 apresenta a média dos resultados do burst produzidos pelos três informantes do experimento, e a média geral do parâmetro segundo cada forma verbal.

\footnotetext{
28 As informações acústicas advindas do burst das oclusivas do PB podem diferenciar o ponto de articulação das oclusivas. A amplitude do burst distingue oclusiva dental de alveolar.
} 
Tabela 6. Valores médios do Burst da oclusiva /d/ em contexto de gerúndio nas Perífrases (P), Orações Reduzidas de Gerúndio (ORG), Frases Foco (FF) em Milissegundos (ms).

\begin{tabular}{|c|c|c|c|c|}
\hline \multicolumn{5}{|c|}{ Burst (ms) } \\
\hline verbo & $\mathbf{P}$ & ORG & FF & $\begin{array}{l}\text { Média do } \\
\text { burst de } \\
\text { /d/ } /\end{array}$ \\
\hline Dando & 7 & 12 & 11 & 10 \\
\hline Brincando & 16 & 10 & 11 & 12 \\
\hline Perdendo & 12 & 12 & 11 & 12 \\
\hline Morrendo & 12 & 15 & 10 & 12 \\
\hline Indo & 10 & 14 & 11 & 12 \\
\hline Saindo & 13 & 11 & 12 & 12 \\
\hline
\end{tabular}

Quanto ao burst, pode-se observar na Tabela 6 que, no dialeto analisado, a oclusiva /d/, em contexto de morfema de gerúndio, apresenta uma explosão momentânea na média de duração de $12 \mathrm{~ms}$, unindo, então, mais pistas acústicas que caracterizam $\mathrm{o} / \mathrm{d} /$ neste contexto no dialeto da região analisada.

Quanto à análise da transição de formantes, observamos a forma dos formantes na passagem articulatória da oclusiva para a vogal adjacente, o que constitui pista que reflete as mudanças na forma do trato vocal durante a transição entre a oclusiva e a vogal. Assim, as medidas de F2 dão pistas sobre o lugar de articulação que classifica o segmento em oclusiva bilabial, alveolar e velar.

Nos dados levantados e descritos na Tabela 7, observamos que as medidas variam bastante, visto que apresentam valores para F2 de 1400-1900Hz. Essas medidas dão pistas de que o F2 do segmento /d/ esteja entre os valores de 1400-2000Hz, fato que requer um olhar mais detalhado do [d] para verificarmos o comportamento dessa transição, pois a freqüência estimada para o F2 de uma velar é $1800 \mathrm{~Hz}$. Desse modo, é necessário verificar mais detalhadamente o comportamento dessa transição acústica. 
Tabela 7.Valores médios da Transição do Formante F2 da oclusiva /d/ em contexto de gerúndio nas Perífrases (P), Orações Reduzidas de Gerúndio (ORG), Frases Foco (FF) em Hertz (Hz).

\begin{tabular}{lc|c|c|c}
\hline \multicolumn{4}{c}{ Transição de Formantes (Hz) } \\
\hline Verbo & Variáveis & P & ORG & FF \\
\hline Dando & 1675 & 1586 & 1480 \\
Brincando & 1852 & 1498 & 1639 \\
Perdendo & 2057 & 1745 & 1953 \\
Morrendo & 2029 & 1988 & 1814 \\
Indo & 1770 & 1832 & 1884 \\
Saindo & 1781 & 1762 & 1727 \\
\hline
\end{tabular}

Devido às características dos informantes e à velocidade de fala ser muito variável, para obtermos os valores da duração absoluta e relativa, optamos por considerar a duração do segmento alvo /ndo/. Dessa forma, obtivemos o valor relativo, multiplicando por 100 a duração média do segmento "-ndo", e dividindo o resultado pelo valor médio da duração da palavra. $\mathrm{O}$ valor final representa a proporção que o morfema de gerúndio ocupa na duração da palavra, indicando, assim, o apagamento ou não do fonema /d/. A Tabela 8 apresenta as medidas obtidas. ${ }^{29}$

Tabela 8. Valores da Duração Relativa em contexto de gerúndio nas Frase Foco (FF) e Frase Foco Reduzida (FFR) em Porcentagem (\%).

\begin{tabular}{l|c|c}
\hline \multicolumn{2}{c}{ Duração Relativa (\%) } \\
\hline Verbo & FF [ndo] & FFR [no] \\
\hline Dando & 47,33 & 31,23 \\
Brincando & 20,65 & 15,79 \\
Perdendo & 25,82 & 18 \\
Morrendo & 34,42 & 22,71 \\
Indo & 67,32 & 42,12 \\
Saindo & 36,26 & 26,84 \\
\hline
\end{tabular}

\footnotetext{
${ }^{29}$ Nesse momento, não verificamos a duração relativa para as perífrases e orações reduzidas porque esses contextos não são comparáveis, visto que, ora o informante reduz o morfema de gerúndio e ora não.
} 
Na Tabela 8, constata-se que a realização de [ndo] tem maior duração em relação à de [no] em todas as formas verbais, permitindo-nos, então, inferir que a aplicação do fenômeno de redução de gerúndio ocorre nas medidas relativas da FFR. Assim, observamos que as pistas fornecidas pelo parâmetro de duração relativa auxiliam juntamente com os outros parâmetros acústicos caracterizadores da consoante [d] a sinalização da presença desse segmento.

\subsubsection{Discussões dos resultados obtidos e das hipóteses levantadas}

Passamos a levar em conta os resultados da inspeção acústica realizada para caracterizarmos a presença de /d/ e as hipóteses levantadas, no início desse trabalho, de que a redução de gerúndio esteja relacionada apenas à informação de morfema de gerúndio e de que apresenta algumas diferenças na aplicação da regra quanto à estrutura sintática. Fizemos o cruzamento das estruturas também no teste de percepção tomandose por base a discussão de Labov (1972) de que a leitura de textos possa ser usada para estudar variações fonológicas, pois, em geral, as variáveis linguísticas exibem uma mudança notável da elicitação mais formal para a leitura menos formal. Dessa forma, a leitura de perífrases e orações reduzidas de gerúndio proporciona uma fala menos formal do que as estruturas de frases focos, e por isso cremos que há um maior uso da forma padrão na Frase Foco uma vez que essa estrutura isola o item lexical de maneira mais formal.

Apresentamos na Tabela 9 a aplicação do processo de apagamento do /d/, por meio da aplicação dos fatores sintáticos Perífrase (P), Oração reduzida de gerúndio 
(ORG) e frase foco (FF) e morfológico de regularidade (REG) e irregularidade (nãoREG) do verbo.

Tabela 9. Variável sintática e morfológica do verbo: número de ocorrências e porcentagem ${ }^{30}$

\begin{tabular}{|c|c|c|c|c|c|c|c|c|}
\hline $\begin{array}{l}\text { Variáveis } \\
\text { Sintática }\end{array}$ & \multicolumn{2}{|c|}{ Perífrase } & \multicolumn{2}{|c|}{$\begin{array}{c}\text { Oração de } \\
\text { gerúndio }\end{array}$} & \multicolumn{2}{|c|}{ Frase Foco } & \multicolumn{2}{|c|}{ Total (\%) } \\
\hline $\begin{array}{l}\text { Variáveis } \\
\text { Morfológica }\end{array}$ & -ndo & - -no & -ndo & -no & -ndo & - no & -ndo & - no \\
\hline Regular & $12(45 \%)$ & $15(55 \%)$ & $\begin{array}{c}14 \\
(52 \%)\end{array}$ & $\begin{array}{c}13 \\
(48 \%)\end{array}$ & $\begin{array}{c}20 \\
(74 \%)\end{array}$ & $7(26 \%)$ & $\begin{array}{c}46 \\
(56 \%)\end{array}$ & $\begin{array}{c}35 \\
(44 \%)\end{array}$ \\
\hline Irregular & $15(55 \%)$ & $12(45 \%)$ & $\begin{array}{c}17 \\
(63 \%)\end{array}$ & $\begin{array}{c}10 \\
(37 \%)\end{array}$ & $\begin{array}{c}22 \\
(81 \%)\end{array}$ & $5(19 \%)$ & $\begin{array}{c}54 \\
(67 \%)\end{array}$ & $\begin{array}{c}27 \\
(33 \%)\end{array}$ \\
\hline Total & $27(50 \%)$ & $27(50 \%)$ & $\begin{array}{c}31 \\
(57 \%)\end{array}$ & $\begin{array}{c}23 \\
(43 \%)\end{array}$ & $\begin{array}{c}42 \\
(78 \%)\end{array}$ & $\begin{array}{c}12 \\
(22 \%)\end{array}$ & & \\
\hline
\end{tabular}

A Tabela 9 mostra que verbo regular de perífrase é o contexto mais propício à redução do gerúndio, pois apresenta $55 \%$ de produções para a forma [no], enquanto todos os outros contextos apresentaram mais de $50 \%$ de realizações para a forma não reduzida [ndo]. Nota-se ainda que, independentemente do contexto sintático, há mais realização de [no] para verbos regulares (44\%) do que para os irregulares (33\%), ao passo que para a realização [ndo] ocorre o inverso, ou seja, $67 \%$ das ocorrências com verbos irregulares e 56\% com regulares. No entanto, é possível afirmar que a informação sobre a regularidade ou não do verbo de fato sinaliza tendência para a aplicação do apagamento do /d/ em morfema de gerúndio. Vale observar também que o contexto de Perífrase apresenta uma neutralização da variação, marcando exatamente $50 \%$ para as realizações de [ndo] e $50 \%$ para as de [no], enquanto os contextos de Oração Reduzida de Gerúndio e de Frase Foco inibem significativamente a aplicação do

\footnotetext{
${ }^{30}$ Mesmo fazendo uso do GoldVarb na análise variacionista, na análise acústica não fizemos uso desse programa em razão de a quantidade dos dados ser muito baixa, suficientes apenas para fazermos uma inspeção. Por isso apresentamos nas tabelas desta subseção apenas valores percentuais e não pesos relativos.
} 
processo, uma vez que apresentam, respectivamente, $57 \%$ e $78 \%$ para a realização da forma [ndo].

Para discutirmos o cruzamento da informação de conjugação verbal com as variáveis sintáticas, seguem os resultados na Tabela 10.

Tabela 10. Variável sintática e conjugação verbal: número de ocorrências

\begin{tabular}{c|c|c|c|c|c|c}
\hline $\begin{array}{l}\text { Variável } \\
\text { Sintática }\end{array}$ & \multicolumn{2}{|c|}{ Perífrase } & \multicolumn{2}{c|}{$\begin{array}{c}\text { Oração de } \\
\text { gerúndio }\end{array}$} & \multicolumn{2}{c}{ Frase Foco } \\
\hline Conjugaçãa & -ndo & - -no & -ndo & -no & -ndo & -no \\
\hline $1^{a}$ & $9(50 \%)$ & $9(50 \%)$ & $8(44 \%)$ & $10(56 \%)$ & $11(\% 61)$ & $7(39 \%)$ \\
$2^{a}$ & $9(50 \%)$ & $9(50 \%)$ & $12(67 \%)$ & $6(33 \%)$ & $14(78 \%)$ & $4(22 \%)$ \\
$3^{a}$ & $9(50 \%)$ & $9(50 \%)$ & $11(61 \%)$ & $7(39 \%)$ & $17(94 \%)$ & $1(6 \%)$ \\
\hline Total & $\mathbf{2 7}$ & $\mathbf{2 7}$ & $\mathbf{3 1}$ & $\mathbf{2 3}$ & $\mathbf{4 2}$ & $\mathbf{1 2}(22 \%)$ \\
& $(50 \%)$ & $(50 \%)$ & $(57 \%)$ & $(43 \%)$ & $(78 \%)$ & \\
\hline
\end{tabular}

Nota-se que a variável Perífrase continua apresentando uma variação de 50\% para cada conjugação, só que, nesse caso, mais neutralizada do que em relação ao fator regularidade do verbo; no entanto, aqui, o cruzamento da informação de $1^{a}$ conjugação e de Oração Reduzida de Gerúndio tende à aplicação de redução, totalizando 56\% das ocorrências nesse contexto. Porém, todos os outros dados da estrutura Oração Reduzida de Gerúndio e Frase Foco apresentam porcentagens maiores que $60 \%$ para as realizações em “-ndo”, revelando-se o contexto que desfavorece a aplicação do processo de redução.

Ao associarmos as informações da Tabela 10 às informações da Tabela 9, verifica-se que, de fato, o contexto de Perifrase é indiferente à aplicação ou não do processo de apagamento, enquanto o contexto de Oração Reduzida de Gerúndio relativamente desfavorece a aplicação da regra e o de Frase foco significativamente desfavorece o apagamento de /d/. Portanto, a estrutura sintática é importante para a 
descrição do fenômeno de apagamento do /d/ em morfema de gerúndio, pois aponta os contextos que favorecem ou desfavorecem a aplicação do fenômeno abordado.

Sendo assim, na presente pesquisa, a análise acústica contribuiu para (i) a caracterização física e objetiva da oclusiva alveolar sonora /d/ nos morfemas de gerúndio dos verbos do PB da região de São José do Rio Preto, e (ii) descrição de forma mais precisa do ponto de vista fonético do processo fonológico de apagamento do /d/ em morfema de gerúndio, muito comum na variedade linguística dessa região.

Passamos, a seguir, a tratar da análise do fenômeno em estudo da perspectiva fonológica.

\subsection{Análise sob a ótica da teoria Lexical}

No primeiro levantamento de dados, feito no nível de iniciação científica, foram identificadas todas as ocorrências de palavras com terminação em “-ndo". Agrupamos, naquele momento, os itens lexicais terminados em "-ndo" em classes gramaticais, segundo Cunha \& Cintra (2001), a saber: adjetivo, advérbio, substantivo, numeral e verbo. Além disso, os verbos foram subdivididos em $1^{a}, 2^{a}$ ou $3^{a}$ conjugação e em presente do indicativo ou gerúndio. Obtivemos a seguinte classificação dos itens lexicais:

Quadro 4. Classificação dos itens lexicais

\begin{tabular}{|c|c|c|c|c|}
\hline \multicolumn{2}{|c|}{ Tipos de itens lexicais } & \multicolumn{3}{|c|}{ Exemplo de item lexical } \\
\hline \multicolumn{2}{|c|}{ Adjetivo } & \multicolumn{3}{|c|}{ Lindo } \\
\hline \multicolumn{2}{|l|}{ Advérbio } & \multicolumn{3}{|c|}{ Quando } \\
\hline \multicolumn{2}{|c|}{ Substantivo } & \multicolumn{3}{|c|}{ Mundo } \\
\hline \multicolumn{2}{|c|}{ Numeral } & \multicolumn{3}{|c|}{ Segundo } \\
\hline \multirow{3}{*}{$\begin{array}{l}\text { Verbo } \\
\text { (todas as } \\
\text { formas) }\end{array}$} & $1^{\mathrm{a}}$ conj. & Mandando & Mando & Mandar \\
\hline & $2^{a}$ conj. & Vendendo & Vendo & Vender \\
\hline & $3^{\mathrm{a}}$ conj. & Dormindo & $\varnothing$ & Dormir \\
\hline
\end{tabular}


Após análise de oitiva dos inquéritos de fala, constatou-se que o processo de redução aplica-se apenas aos verbos, quando /ndo/ constitui marca de gerúndio na variedade riopretense. Os dados obtidos são apresentados na tabela abaixo. Portanto, o processo fonológico ocorre apenas nesse morfema (não ocorrendo em formas como “*Fernano" ou "*quano", respectivamente, Fernando e quando). Dessa maneira, constitui-se não um processo geral da fonologia do Português, mas um processo que se aplica apenas à forma verbal do gerúndio, na variedade do Português que estudamos.

Tabela 11. Resultados da redução de gerúndio

\begin{tabular}{c|c|c}
\hline Forma verbal & "-no" & "-ndo" \\
\hline Gerúndio & $310(62 \%)$ & $183(36,6 \%)$ \\
\hline
\end{tabular}

Os resultados da Tabela 11 mostram que, no dialeto de São José do Rio Preto, em $62 \%$ das ocorrências pesquisadas de verbos terminados em /ndo/, há aplicação do processo fonológico investigado, em todas as faixas etárias e faixas de escolaridade investigadas. Além disso, ao verificarmos que o processo fonológico de apagamento do /d/, no dialeto da região de São José do Rio Preto, ocorre somente nos morfemas de gerúndio, não atingindo então a raiz da palavra, confirmamos a afirmação de Cristófaro Silva (1996) de que o processo não levará a uma reorganização lexical, pois se aplica a partir de informação morfológica dada pelo componente fonológico e morfológico, ou seja, aplica-se apenas às formas de gerúndio.

Conforme prevê o modelo da Fonologia Lexical - já tratado na seção 1 deste texto - a flexão de gerúndio, objeto de nossa reflexão, está no nível $2(\beta)$ do léxico, pois aí inclui-se a flexão regular do verbo. Seguindo esse modelo, procuramos tratar das características dos níveis do léxico, em particular a de gerúndio e dos domínios de 
aplicação do fenômeno de redução do gerúndio. Além disso, pretendemos esclarecer os critérios para a distinção de a regra ser lexical ou pós-lexical no português.

Para iniciar a nossa análise, lembramos que o modelo da Fonologia Lexical é constituído em níveis. Logo, assumimos que as formas que terminam em “-ndo" estão em diferentes níveis do léxico, da seguinte maneira:

a) no nível $1(\alpha)$, que trata de um nível derivacional, incluímos o que, na gramática tradicional, são denominados adjetivos, advérbios, substantivos e numeral terminados em /ndo/;

b) no nível $2(\beta)$, que é o nível flexional, encontram-se as formas verbais terminadas em /ndo/, incluímos aqui as formas verbais de gerúndio e de primeira pessoa do presente do indicativo.

Considerando o comportamento da regra de redução de /ndo/, os processos que levam à forma reduzida ocorrem no nível $\beta$, como explicitado em (13):

$\begin{array}{ll}\text { [falar] } & \\ {[\text { fal[a[ndo]]] }} & \text { sufixação } \\ {[\text { fal[ã[ndo]]] }} & \text { nasalização } \\ {[\text { fal[ã[no]]] }} & \text { apagamento do "d" } \\ {[\text { falãnu }]} & \text { representação fonética }\end{array}$

O processo fonológico de apagamento não ocorre em todas as palavras terminadas em "-ndo" nem em todas as formas verbais, como se exemplifica a seguir:

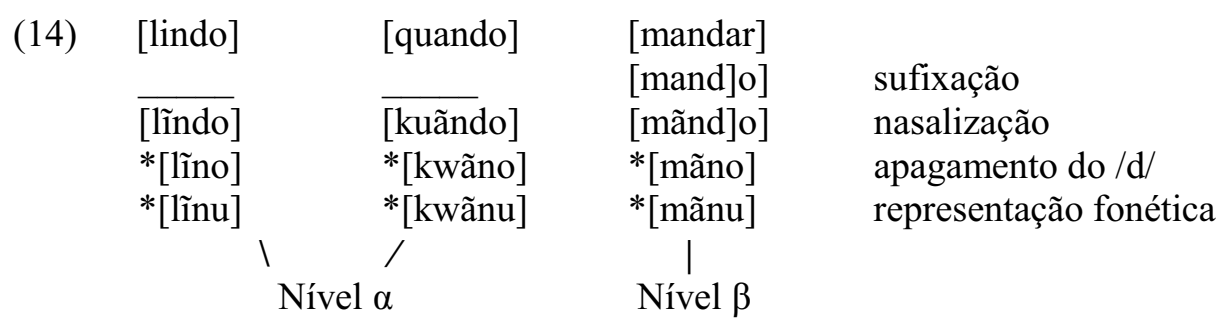


Em (14), as sequências /nd/, no adjetivo lindo, no advérbio quando e no radical do verbo mandar em primeira pessoa do singular do presente do indicativo, não se alteram para $/ \mathrm{n} /$, pois a regra é bloqueada. Note que os itens lexicais em (14) têm contexto segmental propício para que a regra se aplique, isto é, há consoante [+ nasal] seguida de um segmento [+ anterior] e [+ coronal]. Entretanto isso não ocorre. É preciso notar que a consoante nasal /n/, no caso desses itens lexicais, encontra-se na raiz da palavra e não no morfema flexional, como ocorre nas formas de gerúndio. Explicita-se, portanto, que a regra não se aplica a toda sequência /nd/, mas somente ao morfema de gerúndio, informação a ser expressa na regra de apagamento do /d/.

Sendo assim, defende-se que o fenômeno de apagamento do /d/ não se aplica aos itens do nível $\alpha$ nem a todos os itens do nível $\beta$ do léxico, pois, nos dois casos, a regra é bloqueada pelo princípio de Preservação de Estrutura (SP), o qual prevê que somente segmentos contrastivos de cada língua podem ocorrer durante as operações lexicais, determinando os tipos de regras fonológicas que podem se aplicar no léxico de modo a preservar a sua estrutura. Além disso, a aplicação do fenômeno também é condicionada pelo princípio de Condição de Ciclo Estrito (SCC), já que o verbo no gerúndio ocorre somente no nível $\beta$ e esse princípio bloqueia a regra em ambientes não derivados, isto é, aplica-se a regra somente a /ndo/ e não a raízes da palavra. Logo, segundo esses princípios, não ocorrem formas como *[lĩnu] para lindo, no nível $\alpha$, e nem *[mãnu] para mando, no nível $\beta$, porque a aplicação da regra alteraria a estrutura da palavra e atingiria outro nível do léxico. Desse modo, a redução de gerúndio é um fenômeno fonológico que se caracteriza como uma regra lexical no nível $\beta$.

Em (15), mostramos a regra de apagamento do /d/, que se aplica apenas às formas de gerúndio e não a outras formas verbais. Os vários processos fonológicos pelos quais as formas verbais passam também são apresentados a seguir: 


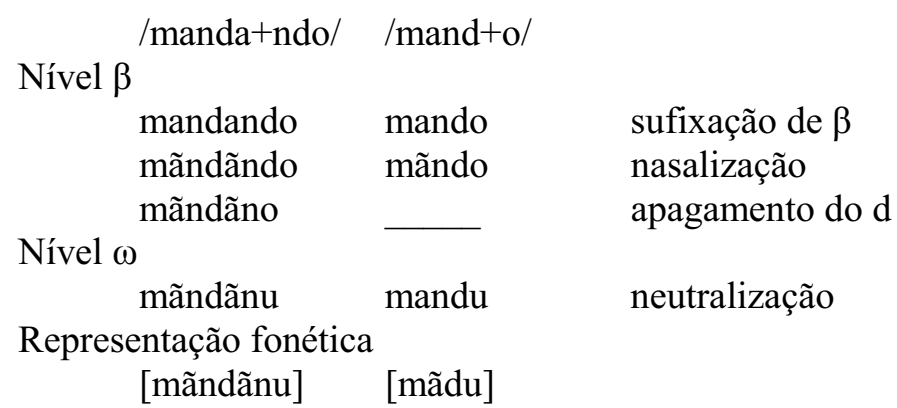

Em (15), vemos que, primeiro, os itens lexicais são atingidos pela sufixação, ou seja, a flexão regular dos verbos; segundo, os itens lexicais são atingidos pelo processo de nasalização; terceiro, a regra de apagamento aplica-se somente à forma de gerúndio, na medida em que os itens lexicais estão sujeitos ao princípio de SP e de SCC e, dessa forma, a regra não se aplica aos termos do nível $\beta$ que não teriam preservado a estrutura do léxico. Logo, demonstra-se que o domínio da aplicação dessa regra lexical é o nível $\beta$.

Lembramos que essa regra de redução de gerúndio é variável, informação que a faria ser regida pela regra pós-lexical. No entanto, a regra não se caracteriza como pós-cíclica porque atinge somente os verbos de gerúndio e não outros itens lexicais, uma vez que se sujeita aos princípios de Preservação de Estrutura e Condição de Ciclo Estrito, princípios aos quais as regras pós-cíclicas não se sujeitam, pois estas regras desconhecem as informações morfológicas. Desse modo, a restrição aqui estudada deve ser regida pela regra lexical visto que é aplicável apenas nos morfemas de gerúndio e não em outras formas lexicais ou entre palavras. ${ }^{31}$

\footnotetext{
${ }^{31}$ Em outras variedades do PB, o fenômeno já está atingindo outros níveis, por exemplo, Mollica (1989) apresenta dados do tipo 'qua[no]' e 'fala[no]' para o dialeto carioca, em que a primeira forma pertence ao nível $\alpha$ e a segunda ao nível $\beta$. Podemos dizer que, nesse dialeto, o apagamento está atingindo outras classes gramaticais e que a sua aplicação é opcional. Uma vez que a regra tem o comportamento variável, esta é de natureza pós-léxical, pois, a gramática aceita as duas realizações (/ndo/ /no/) no dialeto carioca. No entanto, no corpus de nossa pesquisa, não encontramos formas como as de Mollica (1989), mas como falante dessa variedade, ouvimos realizações desses itens lexicais como 'qua[no]'.
} 
Em resumo, com base na Fonologia Lexical, a interação da fonologia e da morfologia organiza o léxico da língua de maneira clara e satisfatória, de modo que a interação entre esses dois domínios ordena a aplicação ou não do apagamento do /d/ a morfema de gerúndio, corroborando-se, assim, a visão segundo a qual a estrutura do léxico é composta de níveis e que, no $\mathrm{PB}$, as regras lexicais se sujeitam aos princípios de Condição de Ciclo Estrito e Preservação da Estrutura.

\subsection{Análise sob a ótica da teoria variacionista}

Com o intuito de verificar como se dá o comportamento variável do fenômeno de apagamento do [d], apresentaremos aqui a análise variacionista dessa regra na variedade falada na região de São José do Rio Preto (SP), com base nos pressupostos teóricos da Sociolinguística (LABOV, 1972).

De modo geral, analisamos 999 ocorrências de formas verbais no gerúndio e verificamos que há alta aplicação da regra na variedade estudada, em 72\% das ocorrências. Esse elevado percentual evidenciou que o fenômeno é uma forte característica da variedade falada na região de São José do Rio Preto (SP). Visualizamos os resultados no Gráfico 3 a seguir: 


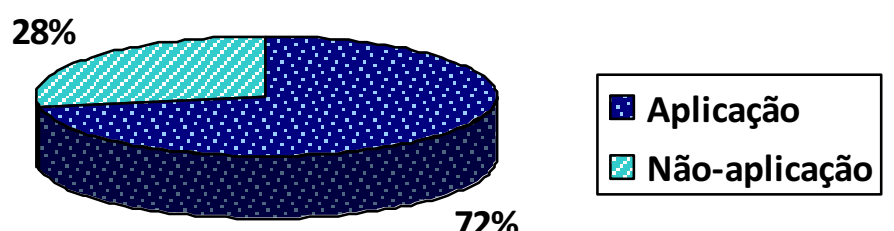

Gráfico 3. Percentual de aplicação e não-aplicação do apagamento do [d] em morfema de gerúndio

Muitos autores, como Amaral (1920), Marroquim (1934), Silva Neto (1956), Coutinho (1967), Melo (1971) entre outros, descreveram o fenômeno de apagamento do [d] em morfema de gerúndio como uma característica do falar "caipira" ou "roceiro", caracterizando o falante que faz uso da regra como inculto e rústico; podemos notar, então, que tal fenômeno é considerado estigmatizado por esses autores.

No entanto, a partir do gráfico apresentado, podemos considerar que os resultados de apagamento do [d] demonstram que o fenômeno está ganhando força na variedade riopretense. Ao longo desta análise, procuramos descrever de que modo esse índice de aplicação do apagamento está estratificado nessa comunidade e verificar em quais segmentos sociais o fenômeno de redução do gerúndio está mais presente.

Observamos os nossos resultados com os de outras variedades do PB encontrados na literatura, para sinalizarmos a tendência da realização do fenômeno em outros dialetos. Na Tabela 12, apresentamos os dados. 
Tabela 12. Percentual de aplicação do apagamento de [d] em morfema de gerúndio em diferentes variedades do PB

\begin{tabular}{c|c|c|c|c|c}
\hline Cidades & $\begin{array}{c}\text { São José do } \\
\text { Rio Preto- } \\
\text { SP }\end{array}$ & $\begin{array}{c}\text { Rio de Janeiro-RJ } \\
\text { (MOLLICA, 1989) }\end{array}$ & $\begin{array}{c}\text { Plameira dos } \\
\text { Índios-AL } \\
\text { (SILVA, 2006) }\end{array}$ & $\begin{array}{c}\text { Custódia-PE } \\
\text { (AMARAL, 2008) }\end{array}$ & $\begin{array}{c}\text { João Pessoa-PB } \\
\text { (MARTINS, 2001) }\end{array}$ \\
\hline Aplicação & $\begin{array}{c}716 / 999 \\
(72 \%)\end{array}$ & $\begin{array}{c}1257 / 4101 \\
(31 \%)\end{array}$ & $\begin{array}{c}11 / 16 \\
(69 \%)\end{array}$ & $\begin{array}{c}326 / 511 \\
(64 \%)\end{array}$ & $\begin{array}{c}2275 / 3892 \\
(58 \%)\end{array}$ \\
\hline
\end{tabular}

Na Tabela 12, verifica-se que há nas variedades do sudeste e do nordeste uma tendência de aplicação do apagamento do [d] em morfema de gerúndio. Os resultados de Amaral (2008) e Martins (2001) distanciam-se um pouco dos outros estudos devido à estratificação social ser diferente, pois não consideraram todas as faixas de escolaridade e idade que estamos analisando em nossa pesquisa. ${ }^{32}$ De todo modo, sinaliza-se a aplicação do fenômeno em diferentes regiões geográficas do país. Além disso, o corpus censo foi compilado no início da década de 80 e o Iboruna, de 2004 a 2007, cerca de 20 anos depois. Portanto, seus dados, visto de uma perspectiva de tempo real, apontam para uma escala progressiva de aplicação de redução conforme a passagem do tempo.

Nas subseções seguintes, passaremos a analisar e discutir os resultados dos grupos de fatores linguísticos e extralinguísticos que norteiam a nossa pesquisa. A sequência da discussão seguirá a ordem de relevância dos grupos de fatores de cada variável linguística e social selecionada pelo programa GoldVarb. A escolha por apresentar primeiro as variáveis linguísticas segue uma sequência de coesão do próprio trabalho, de modo que, fizemos inicialmente uma discussão linguística, a partir da inspeção acústica e análise fonológica, seguida pela análise dos ambientes linguísticos em que o fenômeno tende a ocorrer nessa comunidade de fala. Após essa discussão dos

\footnotetext{
${ }^{32}$ A amostra do trabalho de Martins (2001) está estratificada da seguinte maneira: anos de escolarização nenhum ano; de 1 a 4 anos, de 5 a 8 anos, de 9 a 11 anos e mais de 11 anos; Sexo - feminino e masculino; Faixa Etária - de 15 a 25 anos, de 26 a 49 anos, mais de 50 anos. Já a pesquisa de Amaral (2008) está estratificada em: escolaridade - até 4 anos, mais de 4 anos; faixa etária - de 15 a 30 anos, acima de 30 anos; sexo - feminino e masculino; localidade - zona rural e zona urbana.
} 
fatores linguísticos, realizamos uma análise dos fatores sociais, em que concluímos a análise de base variacionista, a fim de dar explicações sobre o comportamento variável da aplicação do fenômeno de redução de gerúndio.

\subsubsection{Análises das variáveis linguísticas}

Iniciamos a análise variacionista das variáveis linguísticas pela estrutura sintática.

\section{(i) Estrutura sintática}

A estrutura sintática foi a única variável linguística selecionada como relevante pelo programa Goldvarb. Ao analisar os dados, verificamos os seguintes resultados:

Tabela 13. Aplicação (Apl./total), frequência percentual (\%) e peso relativo (PR) do apagamento do [d] em morfema de gerúndio: estrutura sintática

\begin{tabular}{l|c|c|c}
\hline Contextos Morfossintáticos & Apl./total & \% & PR \\
\hline Perífrase & $466 / 643$ & 72 & $\mathbf{. 5 1}$ \\
Oração reduzida de gerúndio & $223 / 322$ & 69 & $\mathbf{. 4 5}$ \\
Justaposição & $23 / 25$ & 92 & $\mathbf{. 8 0}$ \\
Ambíguo (períf/or. Red. Ger.) & $4 / 7$ & 57 & $\mathbf{. 2 5}$ \\
\hline \multicolumn{1}{c|}{ Total } & $716 / 999$ & 72 & \\
\hline \multicolumn{2}{c}{} & & Input 0.764 \\
& & Sig. 0.042
\end{tabular}

Controlamos esse grupo de fatores para detectar se havia algum ambiente sintático mais propício à redução do gerúndio. Assim, ao observarmos a Tabela 13, verificamos que o contexto favorecedor da aplicação é o de justaposição (PR .80), como, por exemplo, em (16):

(16) minha vida foi melhoran(d)o melhoran(d)o melhoran(d)o 
Mas, ao considerar a quantidade de dados nesse contexto, verificamos que compreende $2,5 \%$ de todas as ocorrências e, segundo Guy (1998), esse caso é uma sobreposição. O peso relativo apresentado é conseqüência de uma sobreposição entre o fator justaposição e a probabilidade de input (peso relativo), pois o fator de justaposição representa menos de 5\% de todas as ocorrências, então, esse problema de distribuição distorce a análise dos resultados. Assim, "quase todo o tempo, quando o algoritmo está tentando parcializar efeitos, ele não pode decidir se atribui um efeito ao fator ou à probabilidade de input" (p.37).

Ao tirar justaposição, a variável não é mais selecionada, o que se compreende, pois os pesos relativos que sobraram estão ao redor do ponto neutro ou abaixo dele. Os casos de justaposição, embora em número pequeno, são praticamente todos reduzidos, o que traz uma informação lingüística importante, mas estatisticamente complexa para as limitações do programa. A partir dos resultados apresentados na Tabela 13, a regra parece entrar no sistema pela justaposição e pela perífrase. Então, retomando a Tabela 13, pode-se considerar a importância da perifrase, que é exemplificada em sentenças como (17),

(17) ele tava baten(d)o num molequinho pequenininho...

[AC-005:NE:L.38]

que se mostra relativamente favorecedora (PR .51) à aplicação da regra. Procedendo dessa maneira, obtivemos um resultado mais coerente e mais geral que corrobora a 
nossa hipótese inicial de que as perífrases sejam a construção morfossintática mais favorecedora da redução de gerúndio.

Cabe ainda salientar que foi amalgamado ao contexto de perifrase, o contexto de expressões cristalizadas (marcador discursivo), contexto exemplificado em (18), que havíamos proposto inicialmente nos fatores de análise. Foram encontradas apenas duas ocorrências com estas características, cuja aplicação da regra foi categórica. ${ }^{33}$

(18) Ele falou - "num acredito"- e eu falei - tá ven(d)o?... se eu tivesse falado pra você naquela época você não acreditaria

[AC-063:NE:L.98]

Na Tabela 13, podemos observar ainda que o fator que desfavorece a aplicação da regra é o contexto ambíguo (PR.25) e que o fator oração reduzida de gerúndio (PR.45) é relativamente desfavorecedor. Ambos os fatores são exemplificados, respectivamente, em (19) e (20):

(19) Eu desci lá... fui lá andan(d)o cheguei lá minha avó tinha visto o corte

[AC-037:NE:L.76]

(20) pa escapá(r) de mim eu dei um murrão nele daí ele saiu choran(d)o po banhe::(i)ro

[AC-005:NE:L.51]

Cabe explicitar que ocorrências como (19) foram classificadas como ambíguas porque podem ser classificadas tanto como perífrase quanto como oração reduzida de gerúndio.

\footnotetext{
${ }^{33}$ As expressões cristalizadas poderiam ser entendidas também como perífrase, logo, resolvemos uni-las ao fator perifrase.
} 
(ii) Material interveniente entre V1 e V"ndo" e Tipo de V1 da perífrase

Propomos investigar o grupo de fatores material interveniente entre $V 1$ da perifrase e V"ndo" para verificar se quanto mais distante o V1 da perífrase estivesse do verbo com forma de gerúndio, menor seria a aplicação da regra do morfema de gerúndio; e procuramos verificar, no grupo de fatores tipo de VI da perífrase, se o fato de V1 ser um auxiliar propriamente dito, como, por exemplo, ser, estar, ter e haver (cf. LOBATO, 1975), isso favoreceria a aplicação da redução do morfema de gerúndio. Contudo, nesse momento, os cruzamentos serão em porcentagem, pelo crosstabulation, porque ao fazermos a análise multivariacional as variáveis analisadas foram descartadas pelo programa GoldVarb. Assim, passamos a algumas considerações feitas para o cruzamento desses dois grupos e a variável estrutura sintática.

$\mathrm{Na}$ metodologia, propomos investigar no grupo de material interveniente entre $V 1$ e $V$ "ndo" o número de sílabas de material interveniente, no entanto, obtivemos uma distribuição bastante irregular de dados entre as várias dimensões linguísticas em análise. Para tentar resolver esse problema de distribuição dos dados, passamos a trabalhar com os fatores presença de material interveniente (21a) e ausência de material interveniente (21b)

(21) a. nossa parece que tá até voan $(d) o$ o ônibus...

[AC-109:NE: 1.140]

b. -“oh se cê tá choran(d)o é porque cê fez coisa errada né?-...

[AC-045:NE: 1.82]

Na Tabela 14, apresentamos os resultados do cruzamento da variável estrutura sintática e material interveniente. 
Tabela 14. Número de ocorrências e Frequência percentual (\%) do apagamento do [d] morfema de gerúndio: estrutura sintática X material interveniente entre V1 e V"ndo"

\begin{tabular}{l|c|c|c|c}
\hline \multirow{2}{*}{ Material interveniente } & \multicolumn{2}{|c|}{ Presença } & \multicolumn{2}{c}{ Ausência } \\
\cline { 2 - 5 } Estrutura sintática & Apl./Total & $\%$ & Apl./Total & $\%$ \\
\hline Perífrase & $48 / 69$ & 70 & $418 / 576$ & 73 \\
Oração Reduzida de gerúndio & - & - & $223 / 322$ & 69 \\
Ambíguo (Perífrase/Or. Red. Ger.) & $4 / 7$ & 57 & - & - \\
Justaposição & $4 / 4$ & 100 & $19 / 21$ & 90 \\
\hline
\end{tabular}

Com esse cruzamento, verificamos que há uma distribuição pouco ortogonal entre essas duas dimensões linguísticas analisadas, visto que algumas células da Tabela 14 ficam, obviamente, vazias, devido a combinações impossíveis na estrutura linguística, uma vez que a presença de material interveniente só se relacionaria com os contextos de perifrase e ambíguo. Além disso, ao gerar os valores probabilísticos desse cruzamento, essa variável foi descartada pelo programa, confirmando a irrelevância do grupo de fator material interveniente para o processo. Assim, os resultados mostram o papel pouco relevante de material interveniente e o papel relevante de estrutura sintática, tanto de perífrase quanto de justaposição; nesse caso, embora os dados sejam em número insuficiente, há uma tendência apontada, para a aplicação da regra em perífrase sem material interveniente.

$\mathrm{Na}$ Tabela 15, apresentamos os resultados do cruzamento entre estrutura sintática e o tipo de V1.

Tabela 15. Número de ocorrências e Frequência percentual (\%) do apagamento do [d] morfema de gerúndio: estrutura sintática $X$ tipo de V1

\begin{tabular}{l|c|c|c|c}
\hline \multirow{2}{*}{ Tipo de V1 } & \multicolumn{2}{|c|}{ Auxiliar } & \multicolumn{2}{c}{ Auxiliante } \\
\cline { 2 - 5 } Estrutura sintática & Apl./Total & \% & Apl./Total & $\%$ \\
\hline Perífrase & $247 / 328$ & 75 & $216 / 314$ & 69 \\
Oração Reduzida de gerúndio & - & - & - & - \\
Ambíguo (Perífrase/Or. Red. Ger.) & $2 / 3$ & 67 & $2 / 4$ & 50 \\
Justaposição & $4 / 4$ & 100 & $5 / 7$ & 71 \\
\hline
\end{tabular}


Da mesma forma que o cruzamento analisado anteriormente, o cruzamento do grupo de fatores estrutura sintática e tipo de V1 da perifrase também foi descartado pelo programa Goldvab. A Tabela 15 mostra mais um tipo de distribuição pouco ortogonal dos dados, pois o contexto de perifrase representa $64 \%$ do total das ocorrências investigadas, enquanto que os outros contextos juntos representam cerca de 3\%. Além disso, as células que correspondem ao contexto de oração reduzida de gerúndio estão todas vazias. No entanto, trouxemos esses resultados para apresentar algumas considerações sobre o contexto de perifrase. A Tabela 15 nos revela que as perífrases formadas com auxiliares propriamente ditos (ser, estar, ter e haver) tendem a aplicar mais o processo, uma vez que apresentam um índice de aplicação de $75 \%$ que é maior do que o apresentado para quando ocorrem com "auxiliares" (69\%). Assim, a informação de ser um verbo auxiliar tende a favorecer a aplicação da redução do morfema de gerúndio. Para uma análise mais fundamentada desses resultados, cruzamos as variáveis linguísticas estrutura sintática, material interveniente e tipo de V1 com todas as variáveis sociais abordadas nesta pesquisa, no próximo tópico, seguem as considerações feitas sobre esses cruzamentos.

\subsubsection{Análise das variáveis extralinguísticas}

Nesta subseção, analisamos o comportamento das variáveis sociais em relação ao fenômeno de redução de gerúndio. Antes de iniciar a descrição dos resultados, cabe esclarecer que se fez necessário excluir os dados do informante AC-063, ${ }^{34}$ pertencente à faixa etária de 26 a 35 anos, com nível de escolaridade de $1^{\circ}$ ciclo do ensino

\footnotetext{
${ }^{34}$ No Apêndice D, encontra-se os gráficos que ilustram o número de ocorrências de cada informante.
} 
fundamental, pois, visto que das 76 ocorrências realizadas por esse informante, $97 \%$ delas apresentaram redução do morfema de gerúndio, ou seja, a aplicação é praticamente categórica. Constatamos, por meio de gráficos, que esse informante estava enviesando a amostra, devido a seu comportamento destoar dos demais informantes da mesma.

\section{(i) Faixa etária}

A faixa etária foi a primeira variável selecionada pelo programa como relevante para a aplicação da regra. A Tabela 16 demonstra os resultados desse grupo de fatores.

Tabela 16. Número de aplicação (Apl./total), Frequência percentual (\%) e peso relativo (PR) do apagamento do [d] em morfema de gerúndio: faixa etária

\begin{tabular}{l|c|c|c}
\hline \multicolumn{1}{c|}{ Faixa etária (anos) } & Apl./Total & \% & PR \\
\hline 7 a 15 & $168 / 201$ & 83 & $\mathbf{. 6 3}$ \\
$\mathbf{1 6}$ a 25 & $155 / 201$ & 77 & $\mathbf{. 5 6}$ \\
$\mathbf{2 6}$ a 35 & $138 / 174$ & 79 & $\mathbf{. 6 4}$ \\
36 a 55 & $130 / 204$ & 63 & $\mathbf{. 4 4}$ \\
mais de 55 & $51 / 143$ & 35 & $\mathbf{. 1 7}$ \\
\hline Total & $715 / 997$ & 72 & \\
\hline \multicolumn{3}{r}{} \\
\multicolumn{2}{r}{}
\end{tabular}

Podemos observar que os informantes de 7 a 15 , de 16 a 25 e os de 26 e 35 anos são os que mais aplicam a regra de apagamento do [d] em morfema de gerúndio, com peso relativo, respectivamente, de .63, de .56 e de .64; já os informantes de 36 a 55 anos e os de mais de 55 anos, respectivamente, apresentam PR de .44 e de .17. Assim, em relação ao apagamento do [d] em morfema de gerúndio, constata-se que a aplicação da regra torna-se menos produtiva a partir da faixa etária de 36 a 55 anos e coloca de um lado os mais jovens ( 7 a 15, 16 a 25 e 26 a 35 anos) e de outro os mais velhos. 
No Gráfico 4, podemos verificar o comportamento decrescente da aplicação do apagamento do [d] em morfema de gerúndio em relação à faixa etária.

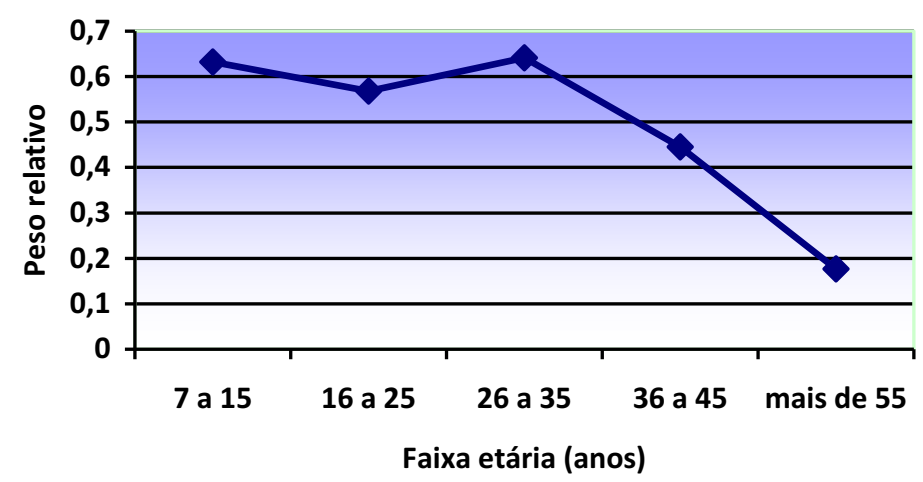

Gráfico 4. Peso relativo da redução do gerúndio a partir da variável Faixa etária

O Gráfico 4 mostra que a aplicação da regra é inversamente proporcional à idade, pois quanto maior a idade, menor é a aplicação da redução do gerúndio. Tais resultados indicam claramente que estamos diante de um processo de mudança em progresso, visto que os pesos relativos dos informantes mais jovens indicam que há uma sobreposição da variante inovadora em relação à variante padrão, diminuindo a frequência em relação à faixa etária dos informantes mais velhos (cf. LABOV, 1972).

Efetuamos ainda uma comparação com resultados de Mollica (1989), cuja pesquisa observou a variedade do Rio de Janeiro (RJ), e de Martins (2001), cuja pesquisa investigou a variedade de João Pessoa (PB). A Tabela 17 mostra essa comparação. 
Tabela 17. Pesos relativos do apagamento do [d] em morfema de gerúndio do grupo de fatores Faixa etária - comparação de duas variedades do PB

\begin{tabular}{l|c|c|c|c|c|c}
\cline { 2 - 7 } \multirow{2}{*}{ Faixa etária } & \multicolumn{5}{c}{ Variedade } \\
\hline & \multicolumn{2}{|c}{ SJRP-SP } & \multicolumn{2}{c}{$\begin{array}{l}\text { Rio de Janeiro-RJ } \\
\text { (MOLLICA, 1989) }\end{array}$} & $\begin{array}{c}\text { João Pessoa-PB } \\
\text { (MARTINS, 2001) }\end{array}$ \\
\cline { 2 - 7 } & Apl./Total & $\%$ & Apl./Total & \% & Apl./Total & $\%$ \\
\hline $\mathbf{7 ~ a ~ 1 5 ~ a n o s ~}$ & $168 / 201$ & 83 & $219 / 1117$ & 20 & - & - \\
\hline $\mathbf{1 6}$ a 55 anos & $423 / 579$ & 73 & $775 / 2035$ & 38 & $1602 / 2577$ & 62 \\
\hline Mais de 55 anos & $51 / 143$ & 36 & $263 / 949$ & 28 & $673 / 1315$ & 51 \\
\hline
\end{tabular}

Como já dissemos antes a metodologia adotada em cada pesquisa não foi a mesma, pois a divisão das faixas etárias foram diferentes da feita pela nossa pesquisa. Entretanto, comparamos as tendências percentuais entre as variedades presentes na Tabela 17 para descrevermos a tendência das faixas etárias nessas regiões. Verificamos que a variedade riopretense difere dos dados de Mollica (1989), uma vez que os falantes cariocas da primeira e da última faixa etária são os que mais tendem a preservar a forma [ndo], apresentando, respectivamente, apenas $20 \%$ e $28 \%$ de apagamento do [d] em morfema de gerúndio. Enquanto que, no dialeto riopretense, somente os falantes mais velhos são os que tendem a preservar a forma padrão. Constata-se assim que há um comportamento indicativo de mudança em progresso em favor da redução do morfema de gerúndio tanto para João Pessoa quanto para São José do Rio Preto, mas uma situação de variação estável no Rio de Janeiro. Segundo Martins (2001), o alto percentual de aplicação da regra nas faixas etárias entre 16 a 55 anos ocorre devido a esses informantes estarem iniciando e/ou exercendo plenamente seu potencial de trabalho e a ser, nesta fase, que os falantes sofrem maior pressão social do grupo ao qual pertencem, por questões identitárias. ${ }^{35}$

\footnotetext{
${ }^{35}$ A faixa etária de Martins (2001) de 16 a 55 anos de idade é uma amalgama, pois, segundo a autora, os pesos relativos das faixas de 16 a 35 anos e de 36 a 55 anos apresentaram pesos relativos bem próximos.
} 
Verifica-se, então, que os dados do dialeto da região de São José do Rio Preto confirmam a hipótese de Labov (1972), que prevê que falantes mais velhos preservam a variante padrão. Além disso, os resultados apresentados na Tabela 17 corroboram a diferença do funcionamento do dialeto carioca e nordestino do dialeto do interior paulista, visto que os falantes se comportam diferentemente diante da aplicação da regra variável em cada região.

\section{(ii) Escolaridade}

Quanto ao fator escolaridade, procuramos estudá-lo porque se mostrou relevante em outros trabalhos variacionistas. Trabalhos como os de Votre (1994), Mollica e Mattos (1989), Martins (2001), entre outros, mostram que a variável escolaridade associa o maior uso da forma padrão a falantes com mais anos de escolarização.

Essa variável foi a segunda mais significativa selecionada pelo Goldvarb em nosso estudo. A Tabela 18 mostra os resultados obtidos.

Tabela 18. Número de aplicaçãol (Apl/Total), Frequência percentual (\%) e peso relativo (PR) do apagamento do [d] em morfema de gerúndio: escolaridade

\begin{tabular}{l|c|c|c}
\hline \multicolumn{1}{c|}{ Escolaridade } & Apl./Total & \% & PR \\
\hline $\mathbf{1}^{\mathbf{0}}$ ciclo do EF & $111 / 129$ & 86 & $\mathbf{. 7 2}$ \\
$\mathbf{2}^{\mathbf{0}}$ ciclo do EF & $177 / 232$ & 76 & $\mathbf{. 5 7}$ \\
Ensino Médio & $241 / 332$ & 73 & $\mathbf{. 4 8}$ \\
Ensino superior & $113 / 230$ & 49 & $\mathbf{. 3 2}$ \\
\hline \multicolumn{2}{r}{} & & Input 0.764 \\
& \multicolumn{3}{l}{ Sig. 0.042}
\end{tabular}

Podemos observar, na Tabela 18, que o fator mais favorecedor da aplicação da regra de apagamento do [d] é o $1^{\circ}$ ciclo do $E F$, seguido pelo fator $2^{\circ}$ ciclo do $E F$ que levemente favorece a aplicação. Enquanto que os fatores ensino médio e ensino superior 
desfavorecem a aplicação da regra. Assim, esses resultados indicam que a regra de apagamento do [d] em contexto de morfema de gerúndio é inversamente proporcional ao aumento do nível de escolaridade, ou seja, quanto mais escolarizado menor a probabilidade da aplicação da regra. Esses resultados demonstram que há uma ratificação das correlações confirmadas em outros trabalhos variacionistas, pois os informantes menos escolarizados $\left(1^{\circ}\right.$ ciclo do $\left.E F\right)$ utilizam a forma não-padrão em maior quantidade do que os informantes mais escolarizados (nível superior).

Verificando os resultados de São José do Rio Preto (SP) com outras variedades para as quais há estudos sobre essa variável, obtivemos os seguintes resultados:

Tabela 19. Frequência percentuais do apagamento de [d] em morfema de gerúndio do grupo de fatores Escolaridade - comparação de três variedades do $\mathrm{PB}^{36}$

\begin{tabular}{l|c|c|c|c|c|c}
\cline { 2 - 7 } \multicolumn{1}{c}{ Escolaridade } & \multicolumn{5}{c}{ Variedade } \\
\hline & \multicolumn{2}{c|}{ SJRP-SP } & \multicolumn{2}{c}{$\begin{array}{c}\text { Custódia-PE } \\
\text { (AMARAL, 2008) }\end{array}$} & $\begin{array}{c}\text { João Pessoa-PB } \\
\text { (MARTINS, 2001) }\end{array}$ \\
\cline { 2 - 3 } & Apl./Total & $\%$ & Apl./Total & $\%$ & Apl./Total & $\%$ \\
\hline $\mathbf{1}^{\mathbf{0}}$ ciclo do ensino fundamental & $111 / 129$ & 86 & $148 / 220$ & 67 & $539 / 799$ & 67 \\
\hline $\mathbf{2}^{\mathbf{0}}$ ciclo do ensino fundamental & $177 / 232$ & 76 & & & $596 / 877$ & 68 \\
\hline Ensino médio & $241 / 332$ & 73 & \multirow{2}{*}{$178 / 291$} & 61 & $313 / 544$ & 58 \\
\hline Ensino superior & $113 / 230$ & 49 & & & $288 / 806$ & 36 \\
\hline
\end{tabular}

Ao verificarmos os resultados apresentados na Tabela 19, notamos que os informantes da região de São José do Rio Preto (SP), de modo geral, reduzem mais a forma de gerúndio mesmo entre os que apresentam maiores graus de escolaridade em relação aos falantes pernambucanos e paraibanos. Constatamos, ainda, que o comportamento do fator Escolaridade é o mesmo em todas as variedades, isto é, diminui a aplicação à medida que aumenta o nível de escolaridade. Por meio da

\footnotetext{
${ }^{36}$ Não inserimos os dados do Rio de Janeiro nesta tabela porque não tivemos acesso ao trabalho completo de Mollica \& Mattos (1989), tivemos acesso apenas a um artigo que as autoras publicaram sobre o padrão etário recorrente em fenômenos de variação fonológica.
} 
escolaridade, devido à aplicação da regra apresentar-se inversamente proporcional ao aumento do grau de escolaridade, comprova-se o pouco prestígio da variante. Assim, concluímos que essa possa ser a tendência para o fenômeno em questão e uma possível explicação para esses resultados seria o fato de os informantes mais escolarizados terem maior conhecimento da gramática normativa e dos seus valores sociais, uma vez que as formas privilegiadas são aquelas provindas da gramática e dos grupos sociais com maior poder econômico, que, consequentemente, na maioria das vezes, são os indivíduos que possuem maior grau de escolaridade.

\section{(iii) Sexo/Gênero}

Dos fatores extralinguísticos, a variável sexo/gênero foi a última variável social selecionada como significativa. A Tabela 20 mostra os resultados para essa variável.

Tabela 20. Número de Aplicação (Apl.Total), Frequência percentual (\%) e peso relativo (PR) do apagamento do [d] em morfema de gerúndio: sexo/gênero

\begin{tabular}{|c|c|c|c|}
\hline Sexo/gênero & Apl./Total & $\%$ & PR \\
\hline Masculino & $327 / 426$ & 77 & .59 \\
\hline Feminino & $315 / 497$ & 63 & .40 \\
\hline
\end{tabular}

Demonstramos, na Tabela 20, que o fator Masculino favorece a aplicação da regra, pois apresenta PR de .59, enquanto o fator Feminino levemente a desfavorece, apresentando PR de .40. Os resultados apresentados para a variedade riopretense confirmam a correlação variacionista de que as mulheres são relativamente mais sensíveis às formas de prestígio (forma padrão). Segundo Labov (1972), essa diferença linguística ocorre porque as mulheres têm mais percepção dos sinais de estratificação social. O autor justifica ainda, que homens e mulheres são socialmente diferentes no 
sentido de que a sociedade lhes confere papéis distintos e, por isso, espera-se que utilizem padrões de comportamento linguístico também distintos, uma vez que a linguagem reflete este fato social.

As pesquisas realizadas por Amaral (2008), na comunidade de Custódia (PE), e por Martins (2001), na comunidade de João Pessoa (PB), sobre esse fenômeno do apagamento, também mostram que os homens são os que tendem a utilizar com maior frequência a variante não-padrão, como se observa na Tabela 21 a seguir.

Tabela 21. Frequências percentuais do apagamento do [d] em morfema de gerúndio do grupo de fatores Sexo/gênero: comparação de três variedades do PB

\begin{tabular}{c|c|c|c|c|c|c}
\hline \multirow{2}{*}{$\begin{array}{l}\text { Sexo/ Cidades } \\
\text { gênero }\end{array}$} & \multicolumn{2}{c|}{$\begin{array}{c}\text { São José do Rio } \\
\text { Preto-SP }\end{array}$} & \multicolumn{2}{c|}{$\begin{array}{c}\text { Custódia-PE } \\
\text { (AMARAL, 2008) }\end{array}$} & \multicolumn{2}{c}{$\begin{array}{c}\text { João Pessoa-PB } \\
\text { (MARTINS, 2001) }\end{array}$} \\
\cline { 2 - 7 } & Apl./Total & $\%$ & Apl./Total & $\%$ & Apl./Total & $\%$ \\
\hline \multicolumn{1}{c}{ Masculino } & $327 / 426$ & 77 & $167 / 230$ & 72 & $1203 / 1940$ & 62 \\
\multicolumn{1}{c|}{ Feminino } & $315 / 497$ & 63 & $159 / 281$ & 57 & $1072 / 1952$ & 55 \\
\hline
\end{tabular}

Os resultados apresentados na Tabela 21 nos fazem concluir que a regra de apagamento do [d] em morfema de gerúndio tem um mesmo comportamento nas três comunidades estudadas na medida em que os resultados dos trabalhos indicam serem as mulheres mais conservadoras que os homens no processo de aceitação social de variantes inovadoras. Sendo assim, a partir dos resultados apresentados até o momento, pode-se dizer que a forma reduzida do gerúndio está mais presente na fala dos mais novos, na dos menos escolarizados e na dos homens. Tais indícios apontam, então, para a tendência de considerá-la como uma forma desprestigiada. Dessa forma, constatamos que o alto índice percentual da variante não-padrão presente na fala dos informantes masculinos, dos jovens e dos falantes com pouca escolaridade assinala um quadro típico de variante inovadora e aponta para a estigmatização da mesma. Os resultados 
assinalam também que a variante inovadora está espraiada socialmente, e, desse modo, para detectar focos sociais de uso, passamos ao cruzamento dos fatores sociais.

\section{- Cruzamento entre variáveis linguísticas e sociais: algumas considerações}

Talvez o leitor tenha se surpreendido com esse cruzamento das variáveis linguísticas e sociais, porque os pressupostos da Sociolinguística as concebem como independentes (GUY \& ZILLES, 2007). Contudo, o cruzamento realizado entre essas variáveis justifica-se pelo fato de investigarmos se há subgrupos dentro do que retificamos como comunidade de fala prototípica. Dessa forma, como o processo de redução do morfema de gerúndio parece ser um caso de mudança em progresso, procuramos investigar com esse cruzamento, se há restrições diferentes no comportamento dos falantes, e, por isso, partimos de uma comunidade de fala não prototípica e mais laboviana.

O cruzamento das variáveis linguísticas e sociais mostrou que as três variáveis linguísticas abordadas tiveram o mesmo comportamento em relação às sociais. ${ }^{37}$

Com relação aos cruzamentos do grupo de fatores material interveniente, de modo geral, podemos observar que o fator masculino e o fator $1^{\circ}$ ciclo do ensino fundamental favorecem a aplicação da regra de redução de gerúndio, quando há ausência de material interveniente, apresentando PR acima de .60; os fatores feminino e ensino superior, independentemente da informação de material interveniente, desfavorecem a aplicação do processo, demonstrando valores probabilísticos abaixo de .49. Quanto ao cruzamento feito entre os grupos de fatores material interveniente e

\footnotetext{
${ }^{37}$ Para maiores esclarecimentos, encontram-se no Apêndice $\mathrm{C}$ as tabelas com os cruzamentos realizados para as considerações presentes nesse tópico.
} 
idade, não obtivemos um bom cruzamento, o programa não selecionou nenhuma variável, pois houve interação e inconvergência.

Com base nos cruzamentos do grupo de fatores Tipo de Vl, verificamos que os fatores masculino, de 7 a 15 anos, de 16 a 25 anos e os fatores $2^{\circ}$ ciclo do ensino fundamental e ensino médio favorecem a aplicação da redução do gerúndio quando o verbo for do tipo auxiliar propriamente dito, pois apresentem PR acima de .60; o fator de 26 a 35 anos favorece a aplicação da regra quando o verbo é do tipo auxiliante (PR.63). Constatamos também que, independentemente do tipo de V1, quanto mais escolarizado o informante, menos ele aplicará a regra. Então, o fator que favorece mais a sua aplicação é o fator $1^{\circ}$ ciclo do ensino fundamental, que demonstra PR de .71 para os verbos do tipo auxiliares e .84 para os verbos auxiliantes.

Por meio do cruzamento do grupo de fatores estrutura sintática, averiguamos que o contexto perifrase produzido por homens é o mais favorecedor da aplicação da regra, apresentando PR de .61; os fatores entre 7 a 25 anos e os de escolaridade entre o $1^{\mathrm{o}}$ e o $2^{\mathrm{o}}$ ciclo do ensino fundamental favorecem mais a aplicação da regra, quando o ambiente é perifrástico, pois, apresentam PR acima de .60; o fator de 26 a 35 anos é o único fator favorecedor da aplicação da regra, quando a estrutura sintática é uma oração reduzida de gerúndio, demonstrando $\mathrm{PR}$ de .79 . Sendo assim, verificamos que, quando o ambiente linguístico é perifrástico, a aplicação da regra é inversamente proporcional à idade e à escolaridade, pois quanto maior a idade e o grau de instrução, menor será a probabilidade de aplicação da redução do gerúndio; já, quando o contexto é oração reduzida de gerúndio, os informantes que tendem a favorecer a regra são os de idade entre 26 a 35 anos. 
Na subseção seguinte, passamos a analisar as variáveis extralingüísticas, com o objetivo de melhor descrever a aplicação do fenômeno de redução do morfema de gerúndio em relação a essas variáveis.

\section{- Cruzamento das variáveis Sexo e Faixa etária}

Para descrevermos mais detalhadamente o comportamento da regra variável estudada nesse trabalho, cruzamos os grupos de fatores idade e sexo dos informantes. Os resultados são dados na Tabela 22.

Tabela 22. Cruzamento entre as variáveis Faixa etária e Sexo: resultado em total de aplicação (Apl./Total), frequência percentual (\%) e peso relativo (PR) do apagamento do [d] em morfema de gerúndio

\begin{tabular}{|c|c|c|c|c|c|c|}
\hline \multirow{2}{*}{$\begin{array}{ll}\text { Faixa etária (anos) } & \text { Sexo/gênero } \\
\end{array}$} & \multicolumn{3}{|c|}{ Masculino } & \multicolumn{3}{|c|}{ Feminino } \\
\hline & Apl./Total & $\%$ & PR & Apl./Total & $\%$ & PR \\
\hline 7 a 15 & $82 / 85$ & 96 & .86 & $86 / 116$ & 74 & .45 \\
\hline 16 a 25 & $75 / 97$ & 77 & .52 & $80 / 104$ & 77 & .55 \\
\hline 26 a 35 & $74 / 80$ & 92 & .86 & $64 / 94$ & 68 & .43 \\
\hline 36 a 55 & $67 / 97$ & 69 & .45 & $63 / 107$ & 59 & .39 \\
\hline mais de 55 & $29 / 67$ & 43 & .22 & $22 / 76$ & 29 & .12 \\
\hline
\end{tabular}

Podemos observar, na Tabela 22, que, de modo geral, os homens mais jovens são os que mais favorecem a aplicação da regra e as mulheres demonstram ser inibidoras da forma não-padrão independentemente da faixa etária. Verificamos que o fator de 16 a 25 anos, para homens e mulheres, é relativamente igual, pois, ambos os fatores neutralizam a aplicação da regra. A Tabela 22 demonstra ainda que os fatores acima de 35 anos, sejam eles homens ou mulheres, desfavorecem a aplicação da regra. Além disso, a partir dos valores probabilísticos, podemos confirmar que, na variedade riopretense, as mulheres pouco favorecem a aplicação, mostrando-se mais conservadoras que os homens. 
O Gráfico 5 deixa claro que é o comportamento dos homens que favorece a aplicação da regra, e que os informantes masculinos de 7 a 15 anos e os de 26 a 35 anos têm o mesmo comportamento linguístico, pois a linha para os homens é mais alta do que a linha para as mulheres, de acordo com o resultado para o fator sexo.

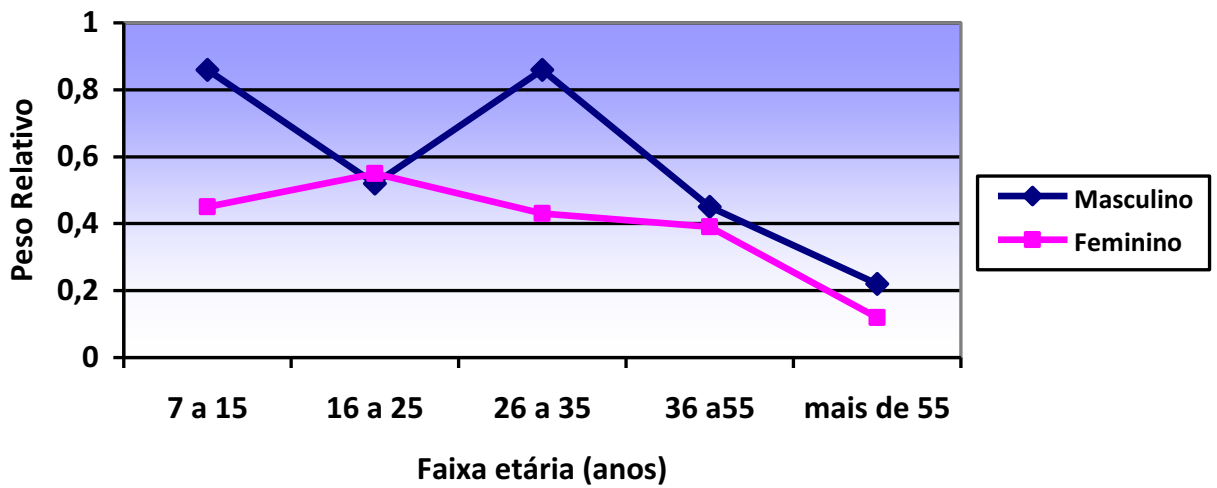

Gráfico 5. Cruzamento das variáveis faixa etária e sexo/gênero: aplicação do apagamento do [d] do morfema de gerúndio (em P.R.). ${ }^{38}$

No Gráfico 5, vê-se que, para as mulheres, nitidamente a linha é descendente, indicando que a variante está sendo usada pelas mulheres mais jovens do que pelas mais velhas. Para os homens, a linha também é descendente, indicando que a variedade está sendo usada pelos homens mais jovens. Além disso, algumas faixas etárias não mostram diferença significativa entre homens e mulheres, como as de 16 a 25 e 36 e 55 anos.

Assim, podemos observar que esses resultados confirmam as correlações de outros trabalhos de que as mulheres, de modo geral, e os falantes de mais idade, quer homens, quer mulheres, preservam mais as formas de prestígio. A aplicação da regra é maior entre os informantes masculinos mais jovens, apresentando uma queda gradativa do apagamento do [d] nos falantes mais velhos (acima de 35 anos). Pode-se dizer, a

\footnotetext{
${ }^{38}$ Os picos dos informantes masculinos de 7 a 15 anos e de 26 a 35 anos apresentados nesse gráfico parecem ser casos individuais de aplicação categórica da regra por algum informante dessas faixas etárias, mas verificamos as taxas de aplicação de cada indivíduo da Amostra Censo e não encontramos aplicação categórica ou quase categórica da regra investigada. A não ser o informante AC-063 (de 26 a 35 anos) que como já dissemos foi retirado das rodadas por apresentar aplicação da regra praticamente categórica.
} 
partir desses resultados que o apagamento do [d] em morfema de gerúndio está indicando mudança em progresso.

Em razão de esta mudança ser liderada pelos homens, com base em Labov (2008, p. 19), podemos esperar que ela ocorra de uma forma mais lenta, pois, segundo o autor, devido ao fato de a maioria das crianças adquirirem a sua primeira língua por meio do sexo feminino, as mudanças avançadas pelos homens são mais lentamente implementadas na comunidade, pois as esposas/mães transmitem uma forma relativamente conservadora a seus filhos. $\mathrm{Na}$ medida em que essas transmissoras de variedade linguística apresentam um comportamento aproximadamente linear em relação ao uso das formas inovadoras, a mudança em progresso tende a ser enfraquecida. Pode-se dizer, ainda em relação ao Gráfico 5, que as mulheres parecem reduzir a aplicação da regra, por utilizarem mais as formas de prestígio, embora as mais jovens apresentem um avanço na utilização da forma inovadora, seguem exatamente a tendência de fortalecimento que os homens lideram.

\section{- Cruzamento da variável Escolaridade e Sexo/gênero}

O intuito do cruzamento das variáveis escolaridade e sexo/gênero é o de verificar o comportamento desses fatores sociais em relação à aplicação do fenômeno de redução do morfema de gerúndio. O cruzamento está demonstrado na Tabela 23.

Tabela 23. Número de Aplicação (Apl./Total), Frequência percentual (\%) e peso relativo (PR) do apagamento do [d] em morfema de gerúndio: escolaridade $X$ sexo

\begin{tabular}{l|c|c|c|c|c|c}
\hline \multicolumn{1}{c|}{ Sexo/gênero } & \multicolumn{3}{c|}{ Masculino } & \multicolumn{3}{c}{ Feminino } \\
\hline Escolaridade & Apl./Total & $\mathbf{\%}$ & PR & Apl./Total & \% & PR \\
\hline $\mathbf{1}^{\mathbf{0}}$ ciclo do EF & $67 / 73$ & 91 & $\mathbf{. 8 3}$ & $44 / 56$ & 78 & $\mathbf{. 6 1}$ \\
$\mathbf{2}^{\mathbf{0}}$ ciclo do EF & $79 / 100$ & 79 & $\mathbf{. 5 7}$ & $98 / 131$ & 74 & $\mathbf{. 5 4}$ \\
Ensino Médio & $119 / 154$ & 77 & $\mathbf{. 5 9}$ & $122 / 178$ & 68 & $\mathbf{. 3 8}$ \\
Ensino superior & $62 / 99$ & 62 & $\mathbf{. 4 5}$ & $51 / 131$ & 39 & $\mathbf{. 2 3}$ \\
\hline \multicolumn{4}{|c}{} & \multicolumn{3}{c}{ Input 0.732} \\
\hline
\end{tabular}


O cruzamento das variáveis demonstra que os homens aplicam mais o apagamento do [d] que as mulheres independentemente da escolaridade. Além disso, a Tabela 23 mostra que o comportamento dos gêneros difere quanto à regressão da aplicação da regra, pois as mulheres apresentam uma queda discreta e os homens uma queda relativamente brusca em termos de peso relativo à medida que aumenta o nível de escolaridade, uma vez que a linha desce no sentido de favorecimento da regra até o EM. Observa-se ainda que as mulheres que possuem o primeiro e o segundo ciclo do ensino fundamental apresentam pesos relativos bem próximos, enquanto que os homens desses mesmos níveis de escolaridade demonstram valores probabilísticos bastante acentuados. Todavia, quando observamos a partir dos dois extremos de escolaridade ( $1^{\circ} \mathrm{EF}$ e ES), os dados mostram que a diferença de PR entre homens e mulheres é exatamente a mesma, isto é, uma diferença de 38 pontos para os dois fatores.

Ao observarmos o Gráfico 6, com o cruzamento ora em análise, verifica-se claramente a tendência do comportamento distinto entre os informantes masculinos e femininos, segundo o nível de escolaridade.

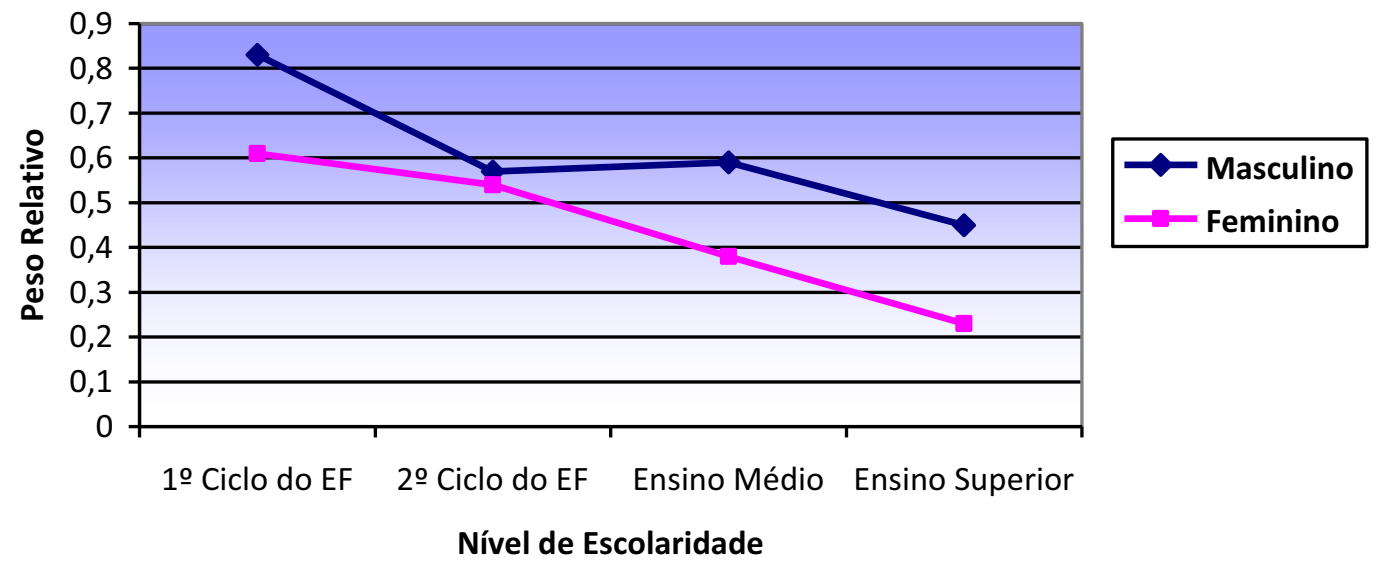

Gráfico 6. Cruzamento das variáveis Escolaridade e Sexo: aplicação do apagamento do [d] do morfema de gerúndio. 
O Gráfico 6 mostra que as linhas têm o mesmo desenho, ou seja, são descendentes. Tanto os homens quanto as mulheres menos escolarizados usam mais o apagamento do que os mais escolarizados. A linha dos homens indica favorecimento maior do que a das mulheres e é indicativa de favorecimento até o EM e a linha das mulheres, até o $2^{\circ} \mathrm{EF}$. Além disso, os resultados indicam que as mulheres mais escolarizadas (EM e ES) são ainda mais sensíveis do que os homens à forma de prestígio, isso confirma uma tendência geral dos estudos variacionistas.

Verificamos no Gráfico 6 que o fator gênero masculino mostra uma tendência para o favorecimento da regra e, conforme o falante vai adquirindo maior nível de escolaridade, a aplicação da regra apresenta-se em regressão. Constatamos ainda que, independentemente do nível de escolaridade, os informantes do sexo masculino aplicam com maior frequência a regra de apagamento; no $2^{\circ}$ Ciclo do ensino fundamental e no nível superior, o comportamento dos homens e das mulheres praticamente é o mesmo. Esses resultados do Gráfico 6 ratificam a afirmação de Labov (2008) de que o uso das formas inovadoras pelas mulheres apresentam um comportamento mais linear do que os homens em relação à implementação dessas formas.

Para finalizar, a partir dos resultados apresentados até o momento, confirmamos que a forma inovadora apresenta-se estigmatizada na comunidade, em razão de as mulheres e os mais escolarizados fazer um uso maior da forma padrão, isto é, da variante prestigiada.

\section{- Cruzamento das variáveis Faixa etária e Escolaridade}

O cruzamento demonstrado na Tabela 24 e visualizado no Gráfico 7 mostra o comportamento dos falantes quanto à faixa etária e à escolaridade. 
Tabela 24. Frequência percentual (\%) e peso relativo (PR) do apagamento do [d] do morfema de gerúndio (RMG): faixa etária X escolaridade

\begin{tabular}{|c|c|c|c|c|c|c|c|c|c|c|c|c|}
\hline Escolaridade & \multicolumn{3}{|c|}{$1^{\circ} \mathrm{EF}$} & \multicolumn{3}{|c|}{$2^{\circ} \mathrm{EF}$} & \multicolumn{3}{|c|}{ EM } & \multicolumn{3}{|c|}{ ES } \\
\hline $\begin{array}{l}\text { Faixa etária } \\
\text { (anos) }\end{array}$ & Apl./Total & $\%$ & PR & Apl./Total & $\%$ & PR & Apl./Total & $\%$ & PR & Apl./Total & $\%$ & PR \\
\hline 7 a 15 & $38 / 43$ & 88 & .70 & $67 / 69$ & 97 & .92 & $63 / 89$ & 70 & .50 & - & - & - \\
\hline 16 a 25 & $28 / 29$ & 96 & .89 & $35 / 48$ & 73 & .49 & $68 / 90$ & 76 & .53 & $24 / 34$ & 71 & .46 \\
\hline 26 a 35 & $22 / 23$ & 95 & .90 & $33 / 42$ & 78 & .60 & $34 / 40$ & 85 & .64 & $49 / 69$ & 71 & .44 \\
\hline 36 a 55 & $10 / 12$ & 83 & .62 & $20 / 36$ & 55 & .28 & 69/93 & 74 & .49 & $31 / 63$ & 49 & .27 \\
\hline mais de 55 & $13 / 22$ & 59 & .32 & $22 / 37$ & 59 & .37 & $9 / 64$ & 14 & .05 & $7 / 20$ & 35 & .10 \\
\hline
\end{tabular}

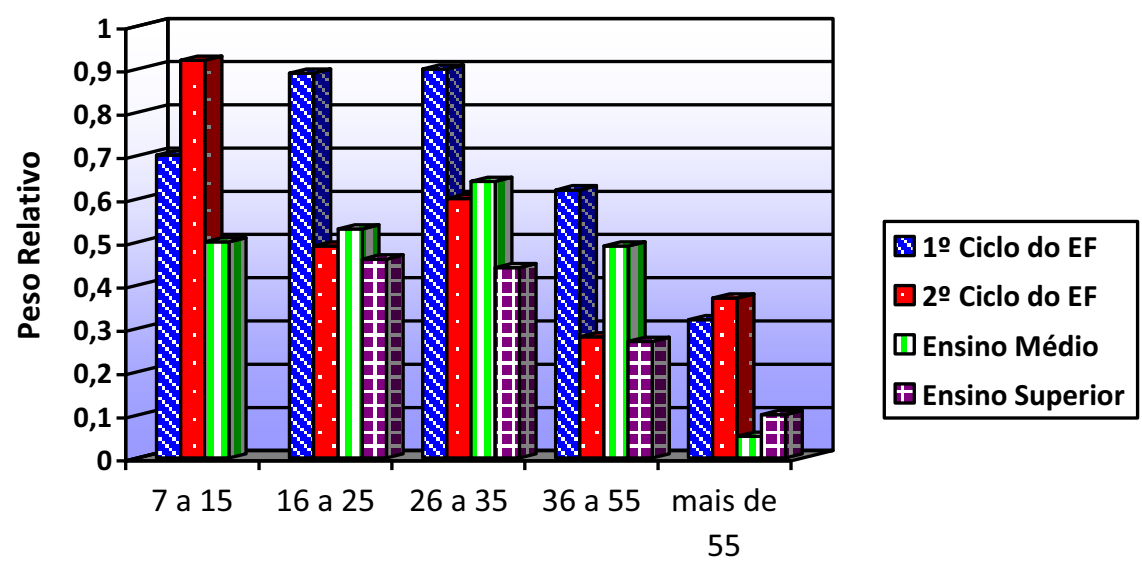

Faixa Etária

Gráfico 7. Cruzamento das variáveis Faixa etária e escolaridade: aplicação do apagamento do [d] do morfema de gerúndio (em P.R.).

Os resultados apresentados na Tabela 24 e no Gráfico 7 mostram que, de modo geral, o fator $1^{\circ}$ ciclo do ensino fundamental é o mais favorecedor da aplicação da regra; na primeira faixa etária (7 a 15 anos), o fator que mais favorece é o $2^{\circ}$ ciclo do ensino fundamental; já os fatores nível superior e mais de 55 anos desfavorecem significativamente a sua aplicação. A partir desses resultados, verificamos que o comportamento dos falantes mais jovens de baixa escolaridade e de idade entre 7 e 35 anos é que favorece a aplicação da regra. Então, esses resultados sustentam a 
interpretação de estigmatização da forma inovadora, pois os falantes mais escolarizados e mais adultos tendem a inibir a implementação da forma inovadora.

A discussão ora realizada permite verificar que a regra variável de apagamento do [d] em morfema de gerúndio caracteriza-se por ser estigmatizada pela comunidade de fala da região de São José do Rio Preto. Esta afirmação deve-se ao fato de o comportamento entre os falantes do sexo feminino e do sexo masculino apresentarem uma diferença marcante, uma vez que são os homens que sofrem influência do processo de escolaridade, e a aplicação da regra se reduz conforme esta aumenta; já o comportamento das mulheres é desfavorecedor da aplicação de apagamento, independentemente de escolaridade. Desse modo, acreditamos que, por a regra não apresentar uma probabilidade significativa de aplicação pelos falantes femininos e/ou escolarizados esses indicadores corroboram a estigmatização da forma inovadora.

\subsection{Resumo}

Nesta seção, apresentamos uma análise quantitativa e qualitativa do fenômeno de apagamento do [d] em morfema de gerúndio sob a ótica da Teoria Acústica, da Fonologia Lexical e da Sociolinguística Variacionista.

$\mathrm{Na}$ subseção 3.1, realizamos uma inspeção acústica do experimento que produzimos para essa finalidade. Ao compararmos a análise perceptivo-auditiva com a inspeção acústica, podemos constatar que nem todos os sons percebidos são os mesmos sons produzidos em uma interação comunicativa. Além disso, a partir da quantificação dos parâmetros acústicos caracterizadores da oclusiva /d/, pudemos descrever melhor este segmento em contexto de gerúndio na variedade de fala da região riopretense. 
Na subseção 3.2, a descrição dos dados sob a ótica da Fonologia Lexical revelou que, na variedade estudada, o processo de redução aplica-se apenas aos verbos quando /-ndo/ indica gerúndio. Assim, embasados nos pressupostos teóricos dessa teoria, de que a estrutura do léxico é composta de níveis e que, no PB, as regras lexicais se sujeitam aos princípios da Fonologia Lexical que são a Condição de Ciclo Estrito e a Preservação da Estrutura, verificamos que o fenômeno fonológico se caracteriza como uma regra lexical no nível $\beta$.

Na subseção 3.3, em razão de o fenômeno se caracterizar na comunidade de fala de São José do Rio Preto como uma regra variável, realizamos a investigação do fenômeno a partir da proposta teórico-metodológica sociolinguísta variacionista, comparando, quando possível, os resultados da variedade riopretense a de outras variedades do $\mathrm{PB}$, tais como, a carioca, a pessoense e a pernambucana. A análise revelou que, na variedade riopretense, a aplicação da regra é altamente frequente (72\%), ou seja, os falantes produzem mais a forma não-padrão, 'fala[no]'. Além disso, verificamos também que os informantes mais jovens são os que mais favorecem a aplicação da regra e os informantes com mais de 55 anos e de nível superior tendem a desfavorecer a regra. Quanto à variável sexo/gênero, os falantes que mais favorecem a aplicação da regra são os homens. Essa descrição revelou também que, das variáveis linguísticas pesquisadas (i) estrutura sintática, (ii) material interveniente entre V1 e V'ndo da perífrase, (iii) tipo de V1 da perífrase, apenas o grupo de fatores estrutura sintática foi selecionado como relevante para a aplicação da regra, em que a estrutura sintática de perifrase é a que favorece a sua aplicação. 


\section{CONSIDERAÇÕES FINAIS}

As considerações finais apresentadas nesta seção trazem o resumo das discussões e conclusões apresentadas nas seções anteriores.

Com base na descrição dos parâmetros acústicos do [d] em contexto de morfema de gerúndio, verificamos que os argumentos apresentam uma perda de qualidade da consoante /d/. Uma vez que os valores numéricos de closura, burst, transição formântica e duração relativa dessa consoante demonstram frequências médias diferentes dos postulados pela literatura, esse efeito possibilita a não percepção de tal segmento no contexto estudado.

A inspeção acústica revelou ainda que, de modo geral, a estrutura sintática Perifrase, como, por exemplo, na sentença Maria está dando um jantar, é o ambiente que mais tende à aplicação da regra de apagamento do /d/ em morfema de gerúndio, enquanto que o ambiente que tende a desfavorecer a aplicação da regra é a estrutura Frase foco, como, por exemplo, em Diga 'morrendo' para ele. Esses resultados revelam que, em um teste de percepção, a estratégia de frase-veículo capta um estilo mais formal do falante do que a tática de construção de frases.

Por meio da inspeção acústica, contribuímos para a caracterização do fenômeno de redução de gerúndio e, em particular, da consoante oclusiva /d/ quando na última sílaba de palavra no $\mathrm{PB}$, na medida em que não há trabalhos de natureza acústica que caracterizam as consoantes do português brasileiro, nem as características acústicas dos segmentos envolvidos nesse fenômeno de redução de gerúndio.

Além disso, a inspeção acústica mostrou uma diferença persistente entre percepção e produção que, no mínimo, permite corroborar uma afirmação de Labov, já questionada na literatura sociolinguística, de que uma comunidade de fala não se 
resume a pessoas que falam do mesmo modo, mas que compartilham as mesmas regras com respeito à variedade adotada. Assim, a análise acústica converge com a análise variacionista no aspecto de que os processos fonológicos variáveis geram diferenças de percepção e produção com muito mais frequência que diferenças do mesmo tipo em processos categóricos.

A descrição baseada nos pressupostos teóricos da Fonologia Lexical (FL), que aborda a interface da fonologia e da morfologia, a partir do conceito de que o léxico se estrutura em níveis, tratou da interpretação fonológica do comportamento do fenômeno de apagamento do /d/ em morfema de gerúndio. Verificamos que esse processo fonológico não ocorre em todas as palavras terminadas em /ndo/, como se exemplifica nos vocábulos "lindo" “*linu” (domínio: nível $\alpha$ ) e "mando" “*manu” (domínio: nível $\beta$ ). Averiguamos também que esses itens lexicais têm apenas contexto segmental para que a regra se aplique, porém, a sequência /ndo/, no caso desses itens lexicais, encontra-se na raiz da palavra e não no morfema flexional, como ocorre no gerúndio. Constatamos que, no dialeto da região de São José do Rio Preto, a regra não se aplica na raiz das palavras, mas sim em um morfema determinado. Sendo assim, a partir da FL, pode-se afirmar que a regra de apagamento não se aplica aos itens do nível $\alpha$ nem a todos os itens do nível $\beta$ do léxico, uma vez que a regra é bloqueada pelo princípio de Preservação da Estrutura. Constatamos ainda que o domínio de aplicação desse fenômeno é o nível $\beta$, em razão de o gerúndio ocorrer somente neste nível, domínio este que é regido pela regra lexical. Esse tipo de regra se sujeita aos princípios de Condição de Ciclo Estrito, que impede a aplicação das regras lexicais nos ambientes não derivados, e ao de Preservação da Estrutura, que bloqueia a regra quando a formação da palavra não favorece a estrutura gramatical da língua. Logo, aplica-se sem problemas 
nas formas de gerúndio, pois se sujeitam a esses princípios e bloqueia-se nas outras formas em que o fonema [d] encontra-se na raiz do item lexical, como em "mando".

Valendo-se das análises acústicas, pode-se dizer que o fenômeno de apagamento do /d/ em morfema de gerúndio é uma regra variável, uma vez que o processo pode não se aplicar mesmo havendo contexto para o apagamento. Por exemplo, os vocábulos "brincando", "sendo" e "conseguindo" alternam-se, respectivamente, entre as realizações 'brinca[nu]' 'brinca[ndo]', 'se[nu]' 'se[ndo]' e 'consegui[nu]' 'consegui[ndo]', evidenciando, assim, que a aplicação da regra não é categórica. Em virtude de ela ser opcional, revelaria uma característica de natureza póslexical; no entanto, para a fala da comunidade de São José do Rio Preto, não assumimos essa posição, porque a regra atinge somente as formas de gerúndio e não outras formas lexicais. Como já dissemos o apagamento do /d/ se sujeita aos princípios de Preservação de Estrutura e Condição de Ciclo Estrito, considerações que favorecem a caracterização de um processo de natureza lexical, uma vez que o domínio pós-cíclico não se sujeita a esses princípios, neste trabalho consideramos o apagamento do [d] no dialeto riopretense é como uma regra lexical.

Verificado que o fenômeno se apresenta como regra variável na língua falada na região de São José do Rio Preto, a descrição quantitativa dos dados possibilita afirmarmos que, de modo geral, o comportamento da regra variável está estratificado e apresenta uma sistematicidade na sua aplicação.

O tratamento feito sob a perspectiva da Sociolingüística Quantitativa mostrou que a forma não-padrão (ausência do /d/ no morfema de gerúndio) é a mais utilizada do que a forma padrão (presença do /d/), assinalando a caracterização de uma forma inovadora que caracteriza a comunidade riopretense na medida em que apresenta percentual de $72 \%$ de uso da forma não-padrão. Além disso, comparando a variedade de 
São José do Rio Preto com a de outras variedades do PB para as quais há estudos de natureza semelhantes, a variedade riopretense é a que mais aplica a regra de apagamento do /d/ em morfema de gerúndio.

Tomando-se por base os resultados descritos na análise variacionista, verificamos que, das seis variáveis analisadas, o programa GoldVarb selecionou quatro delas como sendo relevantes para aplicação da regra variável. Assim, pudemos hierarquizá-las com a seguinte ordem decrescente de relevância:

(22) $\quad$ Sexo/gênero $>$ Escolaridade $>$ Idade $>$ Estrutura Sintática

Em (22), constatamos que os fatores sociais são mais decisivos que os linguísticos. Assim, os resultados mostraram que o grupo de fatores sexo/gênero é a variável mais relevante, pois, em todas as discussões da aplicação da regra, o fator gênero masculino teve comportamento favorável à aplicação da regra. Esse grupo confirmou a hipótese inicial de que informantes do sexo masculino favorecem a aplicação da regra de apagamento do [d] em contexto de morfema de gerúndio, ratificando, então, a correlação variacionista que aponta a diferença entre o comportamento linguístico entre os homens e as mulheres, pois, estas apresentam-se mais conservadoras da norma padrão do que aqueles, demonstrando-se privilegiar as formas de prestígio.

O grupo de fatores Escolaridade também ratificou a nossa hipótese inicial de que quanto maior o grau de instrução menor o uso da forma não-padrão. $O$ comportamento dos falantes de nível universitário, independentemente do sexo, é o fator que desfavorece a aplicação da regra. Dessa maneira, verificamos que a aplicação do apagamento do /d/ é favorecida pelos homens com baixa escolaridade. 
Os resultados, para o grupo de fatores Faixa Etária, confirmaram a nossa hipótese inicial de que os informantes mais velhos usam menos a variante não-padrão do que os informantes mais jovens. Porém, a proporção do apagamento correlacionado com o aumento da idade não é constante, uma vez que os informantes de 16 a 25 anos, aplicam menos a regra do que os informantes da faixa etária anterior e posterior a sua. Além disso, o comportamento dos homens e das mulheres em relação à idade são bem diferentes, pois, à medida que aumenta a idade, as mulheres diminuem o uso da forma inovadora discretamente, enquanto que os homens apresentam queda muito acentuada para essa mesma variável. Constatamos também que as mulheres, independentemente da faixa etária, desfavorecem a aplicação da regra, reafirmando as tendências variacionistas de privilegiarem a forma de prestígio.

Os resultados para o grupo de fatores estrutura sintática apontaram que o contexto de Perifrase, como em sentenças "Ele estava comendo bananas", é relativamente favorecedor à aplicação do apagamento de /d/ em morfema de gerúndio, já os outros ambientes estudados desfavorecem a aplicação da regra. Para melhor descrever o comportamento desse grupo de fatores, cruzamos os pesos relativos desse grupo com os fatores sociais e verificamos que a aplicação da regra de apagamento é favorecida: (i) quanto ao gênero, pela estrutura de Perífrase produzida por homens; (ii) quanto à idade, pela estrutura de Oração reduzida de gerúndio produzida por falantes de 26 a 35 anos; (iii) quanto à escolaridade, pela estrutura perifrástica produzida por falantes com baixa escolaridade. Assim, pode-se dizer que os cruzamentos confirmam a nossa hipótese inicial de que o ambiente mais favorecedor da regra é a perífrase, devido a seu uso ser mais frequente do que os outros contextos analisados. Cabe salientar que as análises das variáveis linguísticas material interveniente e tipo de V1 apresentaram uma subcategoriazação dos dados. No entanto, constatamos que com relação à perífrase, 
ambiente mais favorecedor da aplicação da regra, esses indicadores mostraram uma tendência de aplicação a favor da estrutura perifrástica formada por verbos auxiliares propriamente ditos (ser e estar) e o verbo principal no gerúndio, sem a presença de material interveniente. Essa constatação traz argumento a favor de que o apagamento do /d/ tende a aplicar-se à estrutura de perífrase, ratificando a nossa análise fonológica de que o processo é regido pela regra lexical, pois se a regra está atingindo a perífrase com auxiliares gramaticalizados, logo, é um fenômeno que, na variedade em análise, é melhor descrito como pertencendo ao nível do léxico.

Para finalizar, embasados pela análise variacionista, cremos ser possível afirmar que, em razão de a aplicação da regra na variedade estudada ser alta e de os informantes mais jovens usarem com maior frequência a variante não-padrão e os mais velhos preferirem a forma padrão, as variantes com morfemas de gerúndio reduzido podem ser consideradas formas inovadoras e sua estratificação na comunidade de fala de São José do Rio Preto aponta para uma mudança em tempo aparente.

Esperamos que, por meio da descrição aqui realizada, tenhamos contribuído para os estudos linguísticos no sentido de que este trabalho insere o fenômeno de redução da forma de gerúndio e as características da consoante /d/ do dialeto riopretense nos estudos acústicos, fonológicos e variacionistas no Brasil e, portanto, contribui para o avanço da descrição da variedade linguística do interior do estado de São Paulo, em particular, e para um melhor entendimento do sistema verbal do Português Brasileiro, de modo geral. Dessa forma, almejamos que a análise efetuada sirva de ponto de partida para outros estudos acerca do comportamento variável das formas com terminação em /ndo/ no PB. 


\section{REFERÊNCIAS BIBLIOGRÁFICAS}

ABAURRE, M. B. M. Fonologia: a gramática dos sons. Letras Santa Maria. v. 5, p. 0924, 1993.

. Reflexões sobre a fonologia atual: conceitos de representação, derivação, regras e restrições. In: ABRALIN, 2009, João Pessoa, Conferência.

ALBANO, E. C. O gesto e suas bordas: para uma fonologia acústico-articulatória do português brasileiro. Campinas: Mercado de Letras. 2001.

ALKMIM, T. Sociolinguística: Parte I. In: MUSSALIN, F.; BENTES, A. C. Introdução à lingüística: domínios e fronteiras. São Paulo: Cortez, 2001, p. 21-48.

AMARAL, A. (1920). O dialeto caipira: gramática, vocabulário. 4. ed. São Paulo: HUCITEC; Brasília: INL, 1982.

AMARAL, F. J. do. O Gerúndio na Fala de Custódia-PE: Influências das Restrições Sociais. In: XXI Jornada de Estudos Lingüísticos do Nordeste. GELNE. Maceió. 2008.

ANSHEN, F. Speech Variation among Negroes in a Small Southern Community. Nova York: New York University Press.

BERTUCCI, R. A. A auxiliaridade do verbo chegar em português brasileiro. Dissertação (Mestrado em Letras) - Universidade Federal do Paraná, Setor de Ciências Humanas, Letras e Artes, Curitiba, 2007. Disponível em:

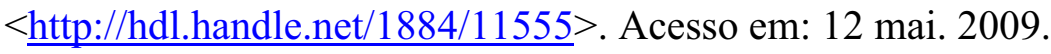

BLOCH, B. A Set of Postulates for Phonemic Analysis. Language, 24: 3-46.

BRAGA, M. L.; CORIOLANO, J. Construções do gerúndio no português do Brasil. Alfa, São Paulo, v. 51, n. 1, p. 175-187, 2007.

BRESCANCINI, C. A análise de regra variável e o programa VARBRUL 2S. In: BISOL, L.; BRESCANCINI, C. Fonologia e variação: recortes do português brasileiro. Porto Alegre: EDIPUCRS, 2002.

CAGLIARI, L. C. Análise fonológica: introdução teoria e a prática com especial destaque para o modelo fonêmico. Campinas: Mercado de Letras, 2002. 
CAMARA JÚNIOR, J. M. Problemas de linguística descritiva. Petrópolis : Vozes, 1970.

. Estrutura da língua portuguesa. 3. ed. Petrópolis : Vozes, 1972.

CAMPOS, O. G. L. A. de S. O gerúndio no português (estudo histórico-descritivo). Tese (Doutorado em Letras) - Faculdade de Filosofia, Letras e Ciências Humanas da Universidade de São Paulo, Araraquara, 1972.

CASTILHO, A.T.; PRETI, D. (Org.) A linguagem falada culta na cidade de São Paulo: diálogos entre dois informantes. v. 2, São Paulo: FAPESP/TAQ, 1987.

CEDERGREN, H.; SANKOFF, D. (1972). Variable: Performance as a Statistical Reflection of Competence. Language, 50 (jun., 1974): 333-355. Disponível em: $<$ http://links.jstor.org/sici?sici $=0097-$

$8507 \% 28197406 \% 2950 \% 3 \mathrm{~A} 2 \% 3 \mathrm{C} 333 \% 3 \mathrm{AVRPAAS} \% 3 \mathrm{E} 2.0 . \mathrm{CO} \% 3 \mathrm{~B} 2-\mathrm{C}>$. Acesso em: 19 mai. 2010.

COLLINSCHONN, G. Fonologia do português brasileiro, da sílaba à frase. Porto Alegre: Gráfica da UFRGS, p. 12-33, 2006.

CONJUNTURA ECONÔMICA DE SÃO JOSÉ DO RIO PRETO. BOLÇONE, O. J. (Org.); LEME, E. M. M. de T. (Coor.). 24. ed. São José do Rio Preto: Secretaria Municipal de Planejamento e Gestão Estratégica, 2009. Disponível em:

$<$ http://www.riopreto.sp.gov.br/PortalGOV/do/subportais_Show?c=146> $>$. Acesso em: 07 nov. 2009.

COUTINHO, I. de L. Pontos de gramática histórica. 6. ed. Rio de Janeiro: Livraria acadêmica, 1967.

CRISTÓFARO SILVA, T. Fonologia: por uma análise integrada à morfologia e à sintaxe. In: Cadernos do Departamento de Letras Vernáculas. Anais da $2^{a}$. Semana de Estudos Portugueses. v. 2, p. 56-65. Belo Horizonte: FALE/UFMG, 1996. Disponível em:

$<$ http://www.projetoaspa.org/cristofaro/publicacao/pdf/originais/artigos/integrada.pdf $>$. Acesso em: 03 nov. 2009.

CUNHA, C.; CINTRA, L. F. L. Nova gramática do português contemporâneo. Rio de Janeiro: Nova Fronteira, 2001.

DALPIAN, L.; MÉA, C. P. D. Do latim ao português: estudos fonético/fonológico, 
2002. Relatório de pesquisa referente ao Edital 05/2001-PRPGP. Disponível em: $<$ www.unifra.br/professores/laurindo/versão\%20final\%20pesquisa $\% 202002$.doc $>$. Acesso em: 10 out. 2006.

FANT, G. Acoustic Theory of Speech Production. Mouton, The Hague, 1960.

FARACO, C. A. A percepção da mudança. Características da mudança. In Linguística Histórica: uma introdução ao estudo da história das línguas. São Paulo: Parábola Editorial, 2005, p. 14-90.

FERREIRA, J. S. A redução do gerúndio no dialeto riopretano. Relatório final de projeto departamental de Iniciação Científica, Universidade Estadual Paulista, São José do Rio Preto, 2007.

FRY, D. B. The physics of speech. Cambridge University Press, 1979.

GAY, T. Effects of filtering and vowel environment on consonant perception. $J$. Acoustic Soc. Am. 48, 1970, p. 993-998. Disponível em:

$<$ http://www.haskins.yale.edu/Reprints/HL0098.pdf>. Acesso em: 14 mar. 2010.

GONÇALVES, S. C. L.O português falado na região de São José do Rio Preto: constituição de um banco de dados anotado para o seu estudo. Relatório final apresentado à FAPESP, São José do Rio Preto, 2007.

. A relevância de variáveis sociais em fenômenos variáveis na fala do interior paulista. In: LIMA-HERNANDES, M. C. et al. (Org.). A língua portuguesa no mundo. 1. ed. São Paulo: FFLCH-USP, p. 1-15, 2008.

GREGIO, F. N. et al. Modelos teóricos de produção e percepção da fala como um sistema dinâmico. Revista CEFAC, São Paulo, v. 8, n. 2, p. 244-247, abr/jun, 2006.

GUY, G. Varbrul: análise avançada. In.: MATTE, N. da S. (Org.). Cadernos de tradução do Instituto de Letras, Universidade Federal do Rio Grande do Sul, Porto Alegre, n. 1, p. 25-47, 1998.

GUY, G. R.; ZILLES, A. Sociolinguística quantitativa - instrumental de análise. São Paulo: Parábola, 2007.

HONÓRIO, D. de S. As alterações de escrita em textos de alunos do ensino médio: conseqüências da oralidade e de convenções ortográficas. Dissertação (Mestrado em 
Linguística Aplicada) - UNISINOS. 2005. Disponível em:

$<$ www.eafce.gov.br/downloads/dissertacaodenise.doc $>$. Acesso em: 10 set. 2006.

HOUSER, A. S. Analog studies of nasal consonants. J. Speech Hear. Disorders 22, p. 190-204, jun. 1957. Disponível em: <jshd.asha.org/cgi/reprint/22/2/190.pdf >. Acesso em: 16 mar. 2010.

IBGE. Censo Demográfico 2000: Características da População e dos Domicílios: Resultados do universo. Disponível em:

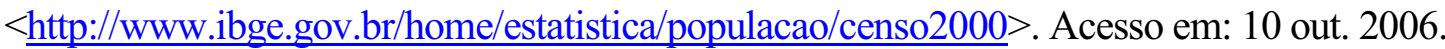

IBGE. Diretoria de Pesquisas, Coordenação de Trabalho e Rendimento, Pesquisa Nacional por Amostra de Domicílios 2005. Disponível em:

$<$ http://www.ibge.gov.br/home/estatistica/populacao/trabalhoerendimento/pnad2005/default.s

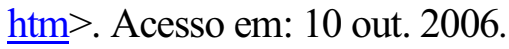

IBGE. Censo Demográfico 2000 : Educação : Resultados da Amostra. Disponível em: $<$ http://www.ibge.gov.br/home/estatistica/populacao/censo2000/default educacao.shtm>. Acesso em: 10 out. 2006.

JOHNSON, K. Digital signal processing. In.: . Acoustic and auditory phonetics. Blackwell, Oxford, 2003.

KAYE, J. D. On the Interaction of Theories of Lexical Phonology and Theories of Phonological Phenomena. In: Phonologica 1988. Cambridge University Press. Pp. 141155. Jun. 1995.

Sobre a Teoria Fonológica de Governo. Curso ministrado na FALE-UFMG.

KAYE, J. D.; VERGNAUD, J. R. Phonology, Morphology and the Lexicon. Paper presented at the 1990 GLOW Colloquium. St's Johns College. Cambrige, 1990.

KENT, R. D.; READ, C. The Acoustic Analysis of Speech. California: Singular Publishing Group Ing, 1992.

KIPARSKY, P. Lexical Morphology and Phonology. Seoul: The linguistic Society of Korea, p. 3-91, 1982.

. Phonological change. In. NEWMEYER, F. J. (ed.), Linguistics: The

Cambridge survey. Vol. I: Linguistic theory-foundations. Cambridge: CUP. 363-415. 
LABOV, W. Contraction, Deletion, and Inherent Variability of the English Copula. Language, Vol. 45, N. 4º (Dez. 1969), p. 715-762. Disponível em:

$<$ http://links.jstor.org/sici?sici $=0097-$ 8507\%28196912\%2945\%3A4\%3C715\%3ACDAIVO\%3E2.0.CO\%3B2-B>. Acesso em: 19 mai. 2010.

. (1972). Padrões sociolinguísticos. Tradução de Marcos Bagno, Maria Marta Pereira Scherre, Carolina Rodrigues Cardoso. São Paulo: Parábola, 2008.

. The intersection of sex and social class in the course of linguist change. Language Variation and Change: Cambridge University Press, n. 2, p. 205-254, 1990.

1994. Principios del cambio lingüístico: factores internos. Vérsión española de Pedro Martín Butragueño. Gredos: Madrid, 1996.

1994. Principios del cambio lingüístico: factores sociales. Vérsión española de Pedro Martín Butragueño. Gredos: Madrid, 1996.

Quantitative Reasoning in Linguistic. Linguistic 353. Jan. 22. Disponível em:

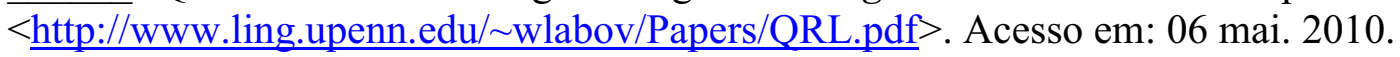

LEE, S. H. Morfologia e Fonologia Lexical do Português do Brasil. Tese (Doutorado em Linguística) - Instituto de Estudos da Linguagem da Universidade Estadual de Campinas, Campinas, 1995.

LEITE, M. Q. Língua falada: uso e norma. In: PRETI, D. (Org.). Estudos de língua falada: variações e confrontos. São Paulo, Humanitas/FFLCH/USP, 1998, p.179-208.

LEMLE, M. Análise sintática: teoria geral e descrição do português. São Paulo: Ática, 1984. (Ensaios; 106).

LEVINE, L.; CROCKETT Jr., H. J. Speech Variation in a Piedmont Community: Postvocalic r, in Lieberson.

LIEBERMAN, P.; BLUMSTEIN, S. E. Speech physiology, speech perception, and acoustic phonetics. Cambridge University Press, 1988.

LOBATO, L. M. P.. Os verbos auxiliares em Português Contemporâneo. Critérios de auxiliaridade. In_. Análises linguísticas. Tradução: Maria Angela Botelho Pereira. Petrópolis: Vozes, 1975. 
MARROQUIM, M. A língua do Nordeste (Alagoas e Pernambuco). São Paulo: Nacional, 1934.

MARTINS, E. F.. Atlas linguístico do Estado de Minas Gerais: o princípio da uniformidade da mudança lingüística nas características fonéticas do português mineiro. Revista Virtual de Estudos da Linguagem - ReVEL. Ano 4, n. 7, ago. 2006. Disponível em: $<$ http://paginas.terra.com.br/educacao/revel/>. Acesso em: 10 out. 2006.

MARTINS, I. F. de M. Apagamento da oclusiva dental /d/ no grupo "ndo" na fala de João Pessoa. Dissertação (Mestrado em Língua Portuguesa) - Centro de Ciências Humanas, Letras e Artes, Universidade Federal da Paraíba, João Pessoa, 2001.

Apagamento da oclusiva dental /d/: perspectivas variacionista e fonológica. In: HORA, D. da. Estudos sociolingüisticos: perfil de uma comunidade. João Pessoa: ILAPEC, 2004. p. 55-82.

McMAHON. M. S. Lexical Phonology and Sound Change: The Case of the Scottish Vowel Length Rule. Journal of Linguistics, Vol. 27, No. 1 (Mar., 1991), pp. 29-53. Cambridge University Press. Disponível em: $<$ http://www.jstor.org/stable/4176091 $>$. Acesso em: 07 dez. 2009.

MELO, G. C. de. (1946). A língua do Brasil. 2. ed. Rio de Janeiro: Fundação Getúlio Vargas, 1971.

MOLLICA, M. C. Um padrão etário recorrente em fenômenos de variação fonológica. Estudos Linguísticos XVII Anais de Seminários do GEL. São Paulo, 1989.

NASCENTES, A. O linguajar carioca. 2. ed. Rio de Janeiro: Organização Simões, 1953.

NOSSO SÃO PAULO. Breve história da região de São José do Rio Preto. Disponível em: <http://www.nossosaopaulo.com.br/Reg_03/Reg03 SaoJoseDoRioPreto.htm>. Acesso em: 07 nov. 2009.

OHALA, J. J. The contribution of acoustic phonetics to phonology. In: B. Lindblom \& S. -hman (eds.), Frontiers of speech communication research. London: Academic Press. $355-363,1979$.

OLIVEIRA, L.; MARIN, S. Patterns of velum coordination in Brazilian Portuguese. PAPI. 2005. Universitat Autònoma de Barcelona, Espanha. 2005. 
PAIVA, M.C. (Org.) Amostras de fala do português falado no Rio de Janeiro. Rio de Janeiro: UFRJ, 1999.

PREFEITURA MUNICIPAL DE SÃO JOSÉ DO RIO PRETO. Disponível em:

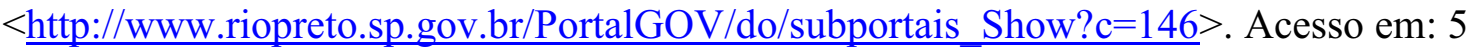
set. 2009.

RUSSO, I.; BEHLAU, M. Percepção da Fala: análise acústica do Português Brasileiro. São Paulo: Lovise, 1993.

SILVA NETO, S. da. História da língua portuguesa. Rio de Janeiro: Livros de Portugal, 1952. . Ensaios de filosofia portuguesa. São Paulo: Nacional, 1956.

SIMÕES, J. da S. Sintaticização, discursivização e semanticização das orações de gerúndio no português brasileiro. v. I e II. Tese (Doutorado em Letras) - Faculdade de Filosofia, Letras Ciências Humanas da Universidade de São Paulo, São Paulo, 2007.

TARALLO, F. A pesquisa sociolinguística. 7. ed. São Paulo: Martins Fontes, 2001.

TEIXEIRA, J. A. O falar mineiro. Revista do Arquivo Municipal de São Paulo, n. 45, ano 4, p. 5-100, mar. 1938.

TRUBETZKOY, N. A fonologia atual. Trad. de R. A. FIGUEIRA. In: DASCAL, M. (Org.) Fundamentos metodológicos da lingüistica: Fonologia e sintaxe. Campinas, Edição do autor, 1981 [1933].

VOTRE, S. Escolaridade. In: MOLLICA, M. C. (Org.). Introdução à sociolinguística variacionista. 2. ed. Cadernos Didáticos. UFRJ, Rio de Janeiro, 1994.

VOTRE, S. J. Relevância da variável escolaridade. In: MOLLICA, M. C., BRAGA, M. L. (orgs.) Introdução à sociolinguística: o tratamento da variação. São Paulo: Contexto, 2003, p. 51-58.

WEINREICH, U; LABOV, W.; HERZOG, M. Fundamentos empíricos para uma teoria da mudança linguística. Tradução de Marcos Bagno. São Paulo: Parábola, 2005. 
WINITZ, H. et al. (1972). Identification of stops and vowels for the burst portion of /p,t,k/ isolated from conversational speech. J. Acoust. Soc. Am. 51, p. 309-1317, 1972.

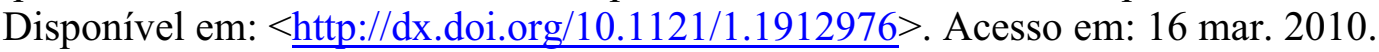

WALFRAM, W; FASOLD, R. W. Foudations of Sociolinguistics. In__. The study of social dialects in American English. Englewood Cliffs: Prentice Hall, 1974. 


\section{APÊNDICE A - Experimento para análise acústica}

Elaborado por: Jesuelem Salvani Ferreira

Colaboradora: Adriana Perpétua

Informante: feminino, idade: , escolaridade: renda familiar:

Data:

1. Diga 'dano' para ele.

2. Talita está indo ao dentista.

3. Pedro saiu brincando pela rua.

4. Diga 'perdeno' para ele.

5. Dara está saindo com César.

6. Talita mostrou-se forte indo ao dentista.

7. Diga 'brincano' para ele.

8. Mário está perdendo o controle.

9. Diga 'morrendo' para ele.

10. Maria está dando um jantar.

11. Diga 'saino' para ele.

12. Paulo está morrendo de saudade.

13. Diga 'perdendo' para ele.

14. Diga 'indo' para ele.

15. Pedro está brincando pela rua.

16. Diga 'dando' para ele.

17. Paulo ficou em casa morrendo de saudade.

18. Diga 'saindo' para ele.

19. Maria acabou o dia dando um jantar.

20. Diga 'morreno' para ele.

21. Mário saiu perdendo o controle.

22. Diga 'ino' para ele.

23. Dara passou meses saindo com César.

24. Diga 'brincando' para ele. 


\section{APÊNDICE B - Tabelas de ocorrências}

Lista dos verbos em que não há redução

$\begin{array}{llllllll}\text { Acalmando } & 01 & \text { Começando } & 03 & \text { Guardando } & 01 & \text { Prestando } & 01 \\ \text { Acostumando } & 01 & \text { Considerando } & 01 & \text { Imitando } & 01 & \text { Pretendendo } & 01 \\ \text { Agradando } & 01 & \text { Criando } & 01 & \text { Incentivando } & 01 & \text { Projetando } & 01 \\ \text { Ajudando } & 01 & \text { Desenvolvendo } & 01 & \text { Influenciando } & 01 & \text { Respeitando } & 01 \\ \text { Apaziguando } & 01 & \text { Divertindo } & 01 & \text { Igualando } & 01 & \text { Rindo } & 01 \\ \text { Aprendendo } & 03 & \text { Enrolando } & 04 & \text { Misturando } & 01 & \text { Superando } & 02 \\ \text { Atrapalhando } & 01 & \text { Entregando } & 02 & \text { Parando } & 03 & \text { Surgindo } & 01 \\ \text { Chacoalhando } & 01 & \text { Esborrachando } & 01 & \text { Passeando } & 01 & \text { Tapeando } & 01 \\ \text { Chifrando } & 01 & \text { Escorando } & 01 & \text { Picando } & 01 & \text { Tratando } & 01 \\ \text { Colecionando } & 01 & \text { Fortalecendo } & 01 & \text { Preparando } & 01 & \text { Vendendo } & 01\end{array}$

Lista dos verbos em que há redução categórica

\begin{tabular}{|c|c|c|c|c|c|c|}
\hline Abanarndo & 01 & Correndo & 26 & Fedendo & 01 & Pedindo \\
\hline Abrindo & 02 & Cuidando & 04 & Ferrando & 01 & Percebendo \\
\hline Abusarndo & 01 & Cursando & 01 & Freando & 05 & Perguntando \\
\hline Acenando & 01 & Dançando & 01 & Fritando & 01 & Piscando \\
\hline Achando & 04 & Decolando & 01 & Ganhando & 01 & Pisando \\
\hline Acreditando & 02 & Deixando & 02 & Garoando & 01 & Pondo \\
\hline Agindo & 01 & Dependendo & 01 & Gerando & 01 & Praticando \\
\hline Aguçando & 01 & Desfilando & 01 & Gostando & 03 & Preferindo \\
\hline Amansando & 05 & Desistindo & 01 & Gritando & 04 & Prevendo \\
\hline Apoiando & 01 & Desmontando & 02 & Insistindo & 01 & Provocando \\
\hline Aproximando & 01 & Despertando & 01 & Insultando & 01 & Puxando \\
\hline Arrastando & 02 & Dirigindo & 06 & Interessando & 01 & Reduzindo \\
\hline Atacando & 01 & Discutindo & 04 & Largando & 02 & Reformando \\
\hline Aumentando & 02 & Durando & 01 & Latejando & 01 & Resumindo \\
\hline Avisando & 02 & Empenhando & 01 & Lecionando & 01 & Revendendo \\
\hline Beirando & 02 & Emprestando & 01 & Limpando & 01 & Revertendo \\
\hline Berrando & 01 & Empurrando & 03 & Mamando & 01 & Revestindo \\
\hline Caindo & 04 & Enchendo & 01 & Manobrando & 01 & Rolando \\
\hline Cambaleando & 02 & Encontrando & 02 & Marcando & 03 & Sangrando \\
\hline Cantando & 03 & Engolindo & 01 & Matando & 02 & Segurando \\
\hline Carregando & 01 & Engravidando & 02 & Mexendo & 04 & Separando \\
\hline Cercando & 02 & Engrenando & 01 & Mobiliando & 01 & Sobrevivendo \\
\hline Chovendo & 01 & Entrevistando & 01 & Montando & 01 & Subindo \\
\hline Combinando & 01 & Envolvendo & 01 & Mostrando & 01 & Teimando \\
\hline Comentando & 01 & Erguendo & 01 & Mudando & 01 & Terminando \\
\hline Comendo & 02 & Escondendo & 01 & Nadando & 01 & Testando \\
\hline Comprando & 03 & Escutando & 01 & Obrigando & 01 & Tocando \\
\hline Confessando & 01 & Estando & 01 & Ocasionando & 01 & Tremando \\
\hline Conquistando & 02 & Esticando & 01 & Opinando & 01 & Ventando \\
\hline Controlando & 01 & Exercendo & 01 & Ouvindo & 01 & Xingando \\
\hline Convidando & 01 & Falecendo & 01 & Parecendo & 02 & Zoando \\
\hline
\end{tabular}


Lista dos verbos em que há redução variável

$\begin{array}{llllllll}\text { Acabando } & 03 & \text { Contando } & 04 & \text { Lendo } & 12 & \text { Rebaixando } & 02 \\ \text { Acontecendo } & 12 & \text { Conversando } & 35 & \text { Levando } & 09 & \text { Resolvendo } & 02 \\ \text { Aguardando } & 04 & \text { Costurando } & 02 & \text { Ligando } & 04 & \text { Sabendo } & 22 \\ \text { Andando } & 11 & \text { Crescendo } & 05 & \text { Mandando } & 03 & \text { Saindo } & 13 \\ \text { Arrastando } & 02 & \text { Dando } & 17 & \text { Mantendo } & 02 & \text { Sentindo } & 07 \\ \text { Arrumando } & 06 & \text { Descendo } & 05 & \text { Melhorando } & 04 & \text { Sendo } & 20 \\ \text { Atendendo } & 02 & \text { Diminuindo } & 02 & \text { Morando } & 12 & \text { Sofrendo } & 02 \\ \text { Batendo } & 06 & \text { Dizendo } & 04 & \text { Morrendo } & 10 & \text { Tentando } & 05 \\ \text { Bebendo } & 05 & \text { Doendo } & 05 & \text { Namorando } & 21 & \text { Tendo } & 09 \\ \text { Bordando } & 03 & \text { Dormindo } & 04 & \text { Olhando } & 08 & \text { Tirando } & 05 \\ \text { Brincando } & 20 & \text { Entendendo } & 07 & \text { Orando } & 05 & \text { Tomando } & 13 \\ \text { Brigando } & 07 & \text { Entrando } & 11 & \text { Passando } & 28 & \text { Trabalhando } & 23 \\ \text { Caminhando } & 03 & \text { Escrevendo } & 03 & \text { Pegando } & 08 & \text { Trazendo } & 02 \\ \text { Casando } & 04 & \text { Esperando } & 19 & \text { Pensando } & 10 & \text { Usando } & 02 \\ \text { Chamando } & 02 & \text { Estudando } & 05 & \text { Perdendo } & 10 & \text { Vendo } & 11 \\ \text { Chegando } & 13 & \text { Falando } & 27 & \text { Pescando } & 04 & \text { Viajando } & 03 \\ \text { Chorando } & 22 & \text { Fazendo } & 32 & \text { Planejando } & 03 & \text { Vindo } & 12 \\ \text { Conhecendo } & 02 & \text { Ficando } & 09 & \text { Precisando } & 04 & \text { Virando } & 03 \\ \text { Conseguindo } & 05 & \text { Indo } & 32 & \text { Procurando } & 06 & \text { Vivendo } & 07 \\ \text { Construindo } & 03 & \text { Jogando } & 08 & \text { Querendo } & 07 & \text { Voando } & 02\end{array}$




\section{APÊNDICE C - Cruzamentos entre as variáveis linguísticas e as variáveis sociais}

Tabela 25. Cruzamento das variáveis: Tipo de V1 X. gênero

\begin{tabular}{l|c|c|c|c|c|c}
\hline \multirow{2}{*}{ Tipo de V1 /gênero } & \multicolumn{3}{|c|}{ Masculino } & \multicolumn{3}{c}{ Feminino } \\
\cline { 2 - 7 } & Apl./Total & \% & PR & Apl./Total & \% & PR \\
\hline Auxiliar & $110 / 128$ & 86 & .696 & $117 / 180$ & 65 & .416 \\
\hline Auxiliante & $99 / 144$ & 69 & .514 & $98 / 155$ & 63 & .514 \\
\hline
\end{tabular}

Log likelihood $=-481.549 \quad$ Significance $=0.000 \quad$ Input 0.736

Tabela 26. Cruzamento das variáveis: Tipo de V1 X idade

\begin{tabular}{l|c|c|c|c|c|c}
\hline \multirow{2}{*}{ Tipo de V1 } & \multicolumn{3}{|c|}{ Auxiliar } & \multicolumn{3}{c}{ Auxiliante } \\
\cline { 2 - 7 } Idade & Apl./Total & \% & PR & Apl./Total & \% & PR \\
\hline 7 a 15 anos & $70 / 78$ & 90 & .707 & $32 / 42$ & 76 & .515 \\
\hline 16 a 25 anos & $57 / 69$ & 83 & .651 & $53 / 73$ & 73 & .504 \\
\hline 26 a 35 anos & $48 / 69$ & 70 & .538 & $42 / 52$ & 81 & .637 \\
\hline 36 a 55 anos & $40 / 57$ & 70 & .590 & $46 / 72$ & 64 & .383 \\
\hline Mais de 55 anos & $12 / 35$ & 34 & .165 & $24 / 60$ & 40 & .196 \\
\hline
\end{tabular}

Log likelihood $=-490.148 \quad$ Significance $=0.020$ Input 0.726

Tabela 27. Cruzamento das variáveis: Tipo de V1 X escolaridade

\begin{tabular}{l|c|c|c|c|c|c}
\hline \multirow{2}{*}{$\begin{array}{c}\text { Tipo de V1 } \\
\text { Escolaridade }\end{array}$} & \multicolumn{3}{c|}{ Auxiliar } & \multicolumn{3}{c}{ Auxiliante } \\
\cline { 2 - 7 } & Apl./Total & \% & PR & Apl./Total & \% & PR \\
\hline $\mathbf{1}^{\mathbf{0}}$ ciclo do EF & $39 / 45$ & 87 & .716 & $27 / 29$ & 93 & .841 \\
\hline $\mathbf{2}^{\mathbf{0}}$ ciclo do EF & $67 / 82$ & 82 & .609 & $64 / 90$ & 71 & .549 \\
\hline Ensino Médio & $78 / 95$ & 82 & .603 & $77 / 110$ & 67 & .392 \\
\hline Ensino Superior & $43 / 86$ & 50 & .290 & $32 / 70$ & 46 & .302 \\
\hline
\end{tabular}

Log likelihood $=-475.755 \quad$ Significance $=0.038$ Input 0.734

Tabela 28. Cruzamento das variáveis: Material interveniente X gênero

\begin{tabular}{l|c|c|c|c|c|c}
\hline \multirow{2}{*}{$\begin{array}{r}\text { Gênero } \\
\text { Material interveniente }\end{array}$} & \multicolumn{3}{|c|}{ Masculino } & \multicolumn{3}{c}{ Feminino } \\
\cline { 2 - 7 } & Apl./Total & $\%$ & PR & Apl./Total & \% & PR \\
\hline Presença & $24 / 32$ & 75 & .517 & $33 / 49$ & 67 & .467 \\
\hline Ausência & $303 / 394$ & 77 & .604 & $282 / 448$ & 63 & .410 \\
\hline
\end{tabular}

Log likelihood $=-479.634$

Significance $=0.000$ Input 0.727 
Tabela 29. Cruzamento das variáveis: Material interveniente X. idade (esse cruzamento não é bom)

\begin{tabular}{l|c|c|c|c|c|c}
\hline \multirow{2}{*}{$\begin{array}{l}\text { Material interveniente } \\
\text { Idade }\end{array}$} & \multicolumn{3}{|c|}{ Presença } & \multicolumn{3}{c}{ Ausência } \\
\cline { 2 - 7 } & Apl./Total & $\%$ & PR & Apl./Total & $\%$ & PR \\
\hline 7 a 15 anos & $13 / 14$ & 93 & .887 & $155 / 187$ & 83 & .594 \\
\hline 16 a 25 anos & $22 / 25$ & 88 & .758 & $133 / 176$ & 76 & .535 \\
\hline 26 a 35 anos & $15 / 17$ & 88 & .816 & $123 / 157$ & 78 & .606 \\
\hline 36 a 55 anos & $7 / 7$ & 50 & .327 & $123 / 190$ & 65 & .758 \\
\hline Mais de 55 anos & $0 / 11$ & - & - & $51 / 132$ & 39 & .192 \\
\hline
\end{tabular}

No Convergence at Iteration 20; $\log$ likelihood $=-475.887$; Significance $=0.036$; Input 0.721

Tabela 30. Cruzamento das variáveis: Material interveniente X escolaridade

\begin{tabular}{l|c|c|c|c|c|c}
\hline \multirow{2}{*}{$\begin{array}{l}\text { Material interveniente } \\
\text { Escolaridade }\end{array}$} & \multicolumn{3}{|c|}{ Ausência } & \multicolumn{3}{c}{ Presença } \\
\cline { 2 - 7 } & Apl./Total & \% & PR & Apl./Total & \% & PR \\
\hline $\mathbf{1}^{\mathbf{0}}$ ciclo do EF & $107 / 125$ & 86 & .721 & $4 / 4$ & 100 & - \\
\hline $\mathbf{2}^{\mathbf{0}}$ ciclo do EF & $152 / 198$ & 77 & .585 & $25 / 34$ & 74 & .565 \\
\hline Ensino Médio & $224 / 306$ & 73 & .491 & $17 / 26$ & 65 & .371 \\
\hline Ensino Superior & $102 / 213$ & 48 & .309 & $11 / 17$ & 65 & .512 \\
\hline
\end{tabular}

Log likelihood $=-478.835 \quad$ Significance $=0.000$ Input 0.727

Tabela 31. Cruzamento das variáveis: Estrutura sintática X gênero

\begin{tabular}{l|c|c|c|c|c|c}
\hline \multirow{2}{*}{ Gênero } & \multicolumn{3}{|c|}{ Masculino } & \multicolumn{3}{c}{ Feminino } \\
\cline { 2 - 7 } & Apl./Total & $\%$ & PR & Apl./Total & $\%$ & PR \\
\hline Perífrase sintática & $198 / 257$ & 77 & .610 & $215 / 334$ & 64 & .434 \\
\hline Oração reduzida de gerúndio & $115 / 151$ & 76 & .592 & $87 / 149$ & 58 & .358 \\
\hline Ambíguo (perífr./Or.Red.G.) & $2 / 2$ & 50 & .219 & $2 / 3$ & 67 & .357 \\
\hline Justaposição & $12 / 14$ & 86 & .693 & $11 / 11$ & 100 & - \\
\hline Log likelihood $=-476.574$ & \multicolumn{4}{c}{ Significance $=0.000$ Input 0.727}
\end{tabular}

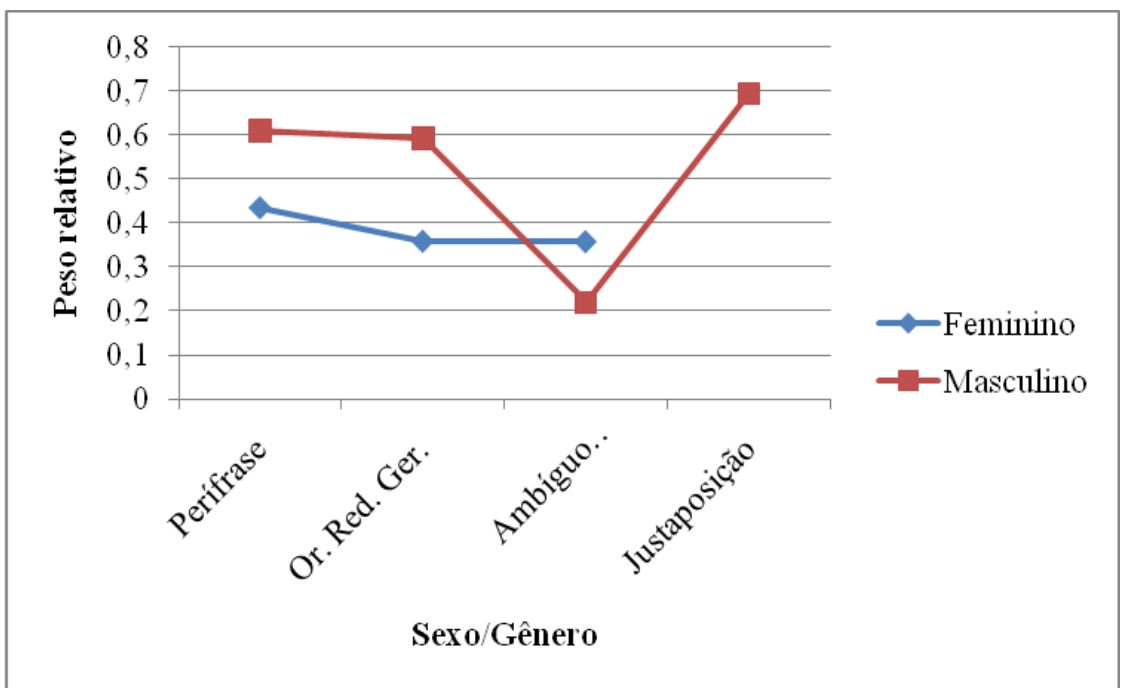

Gráfico 8. Peso relativo do cruzamento das variáveis Estrutura sintática e Sexo/gênero 
Tabela 32. Cruzamento das variáveis: Estrutura sintática $X$ idade

\begin{tabular}{|c|c|c|c|c|c|c|c|c|c|c|c|c|}
\hline \multirow{2}{*}{$\begin{array}{l}\text { Estrutura } \\
\text { sintática } \\
\text { Idade }\end{array}$} & \multicolumn{3}{|c|}{ Perífrase } & \multicolumn{3}{|c|}{ Or. Red. Ger. } & \multicolumn{3}{|c|}{ Ambíguo } & \multicolumn{3}{|c|}{ Justaposição } \\
\hline & Apl./Total & $\%$ & PR & Apl./Total & $\%$ & PR & Apl./Total & $\%$ & PR & Apl./Total & $\%$ & PR \\
\hline $\begin{array}{l}7 \text { a } 15 \\
\text { anos } \\
\end{array}$ & $99 / 117$ & 85 & .635 & $60 / 75$ & 80 & .581 & $2 / 2$ & 100 & - & $7 / 7$ & 100 & - \\
\hline $\begin{array}{l}16 \text { a } 25 \\
\text { anos }\end{array}$ & $109 / 138$ & 79 & .613 & $41 / 55$ & 75 & .507 & $1 / 3$ & 33 & .093 & $4 / 5$ & 80 & .657 \\
\hline $\begin{array}{l}26 \text { a } 35 \\
\text { anos }\end{array}$ & $86 / 117$ & 74 & .586 & $45 / 50$ & 90 & .799 & $1 / 0$ & 100 & - & $6 / 6$ & 100 & - \\
\hline $\begin{array}{l}36 \text { a } 55 \\
\text { anos }\end{array}$ & $84 / 42$ & 67 & .496 & $41 / 72$ & 57 & .359 & $0 / 1$ & - & - & $5 / 5$ & 100 & - \\
\hline $\begin{array}{l}\text { Mais de } \\
55 \text { anos }\end{array}$ & $35 / 93$ & 38 & .195 & $15 / 48$ & 31 & .151 & - & - & - & $1 / 1$ & 50 & .243 \\
\hline
\end{tabular}

Log likelihood $=-473.987$

Significance $=0.000$ Input 0.728

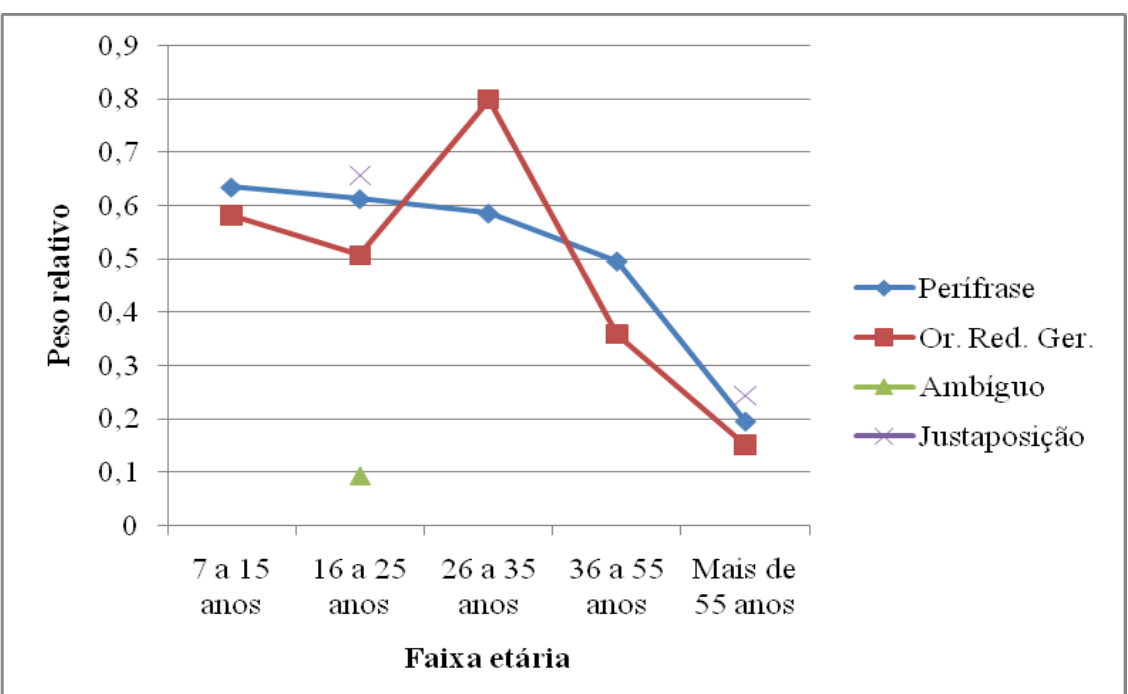

Gráfico 9. Peso relativo do cruzamento das variáveis Estrutura sintático e Faixa etária

Tabela 33. Cruzamento das variáveis: Estrutura sintática X. escolaridade

\begin{tabular}{|c|c|c|c|c|c|c|c|c|c|c|c|c|}
\hline \multirow{2}{*}{$\begin{array}{r}\text { Estrutura } \\
\text { sintática } \\
\text { Escolaridade }\end{array}$} & \multicolumn{3}{|c|}{ Perífrase } & \multicolumn{3}{|c|}{ Or. Red. Ger. } & \multicolumn{3}{|c|}{ Ambíguo } & \multicolumn{3}{|c|}{ Justaposição } \\
\hline & Apl./Total & $\%$ & PR & Apl./Total & $\%$ & PR & Apl./Total & $\%$ & PR & Apl./Total & $\%$ & PR \\
\hline $\begin{array}{l}1^{\circ} \text { ciclo do } \\
\text { EF }\end{array}$ & $65 / 73$ & 89 & .778 & $41 / 51$ & 80 & .651 & - & - & - & $5 / 5$ & 100 & - \\
\hline $\begin{array}{l}2^{\circ} \text { ciclo do } \\
\text { EF }\end{array}$ & $127 / 166$ & 77 & .604 & $41 / 55$ & 75 & .515 & $1 / 3$ & 33 & .099 & $8 / 8$ & 100 & - \\
\hline $\begin{array}{l}\text { Ensino } \\
\text { Médio }\end{array}$ & $146 / 197$ & 74 & .502 & $85 / 123$ & 69 & .439 & $2 / 3$ & 67 & .414 & $8 / 9$ & 89 & .700 \\
\hline $\begin{array}{l}\text { Ensino } \\
\text { Superior }\end{array}$ & $75 / 155$ & 48 & .315 & $35 / 71$ & 49 & .334 & $1 / 1$ & $\overline{100}$ & - & $2 / 3$ & 67 & .586 \\
\hline
\end{tabular}




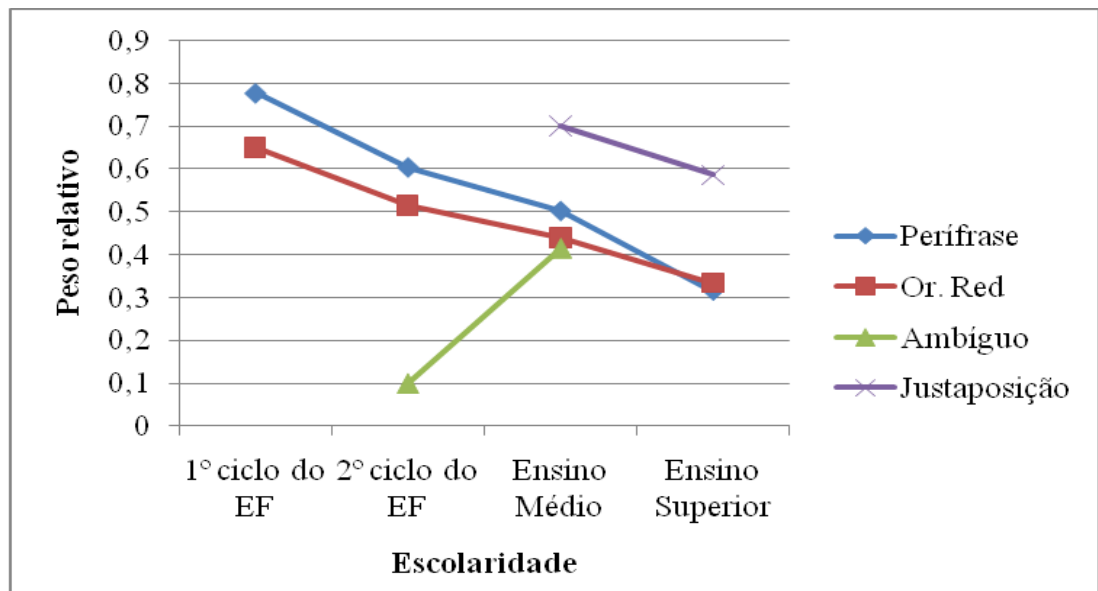

Gráfico 10. Probabilidades do cruzamento das variáveis Estrutura sintática e escolaridade. 
APÊNDICE D - Gráficos do comportamento dos informantes femininos e masculinos e Tabela de características sociais dos informantes de cada AC.

INFORMANTES FEMININOS

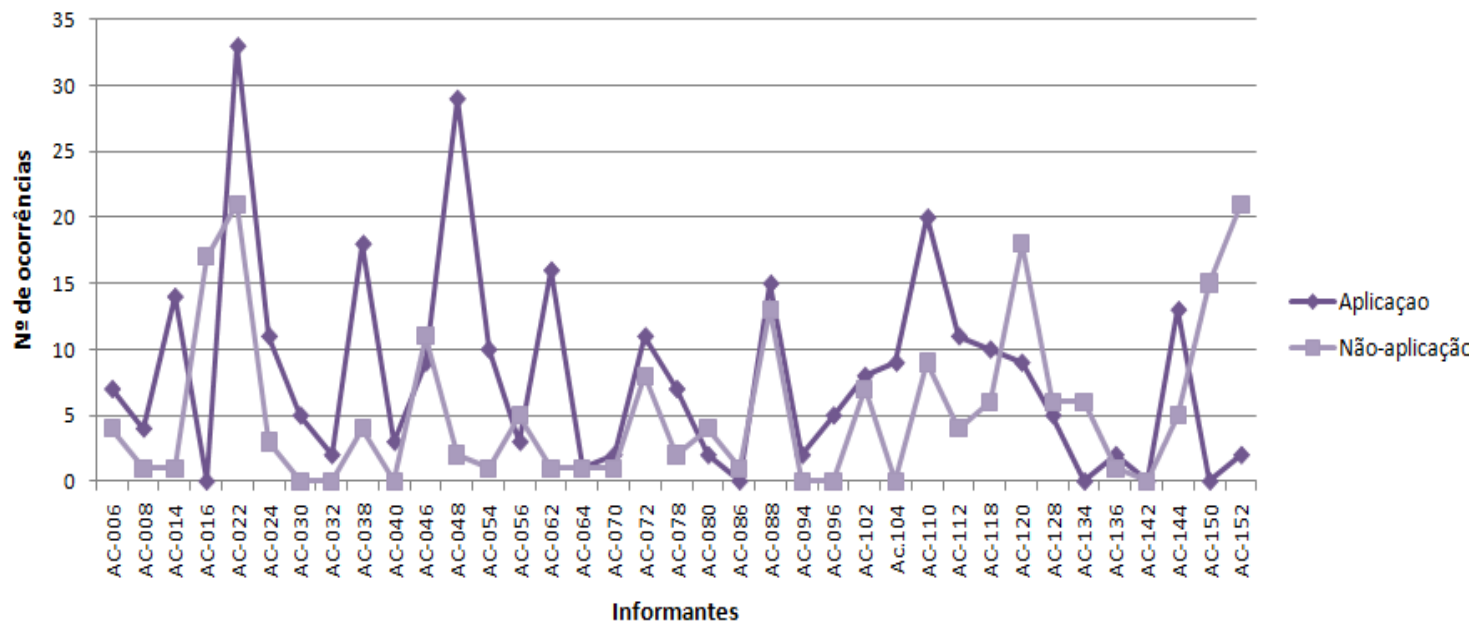

Gráfico 11. Número de ocorrências por informantes femininos

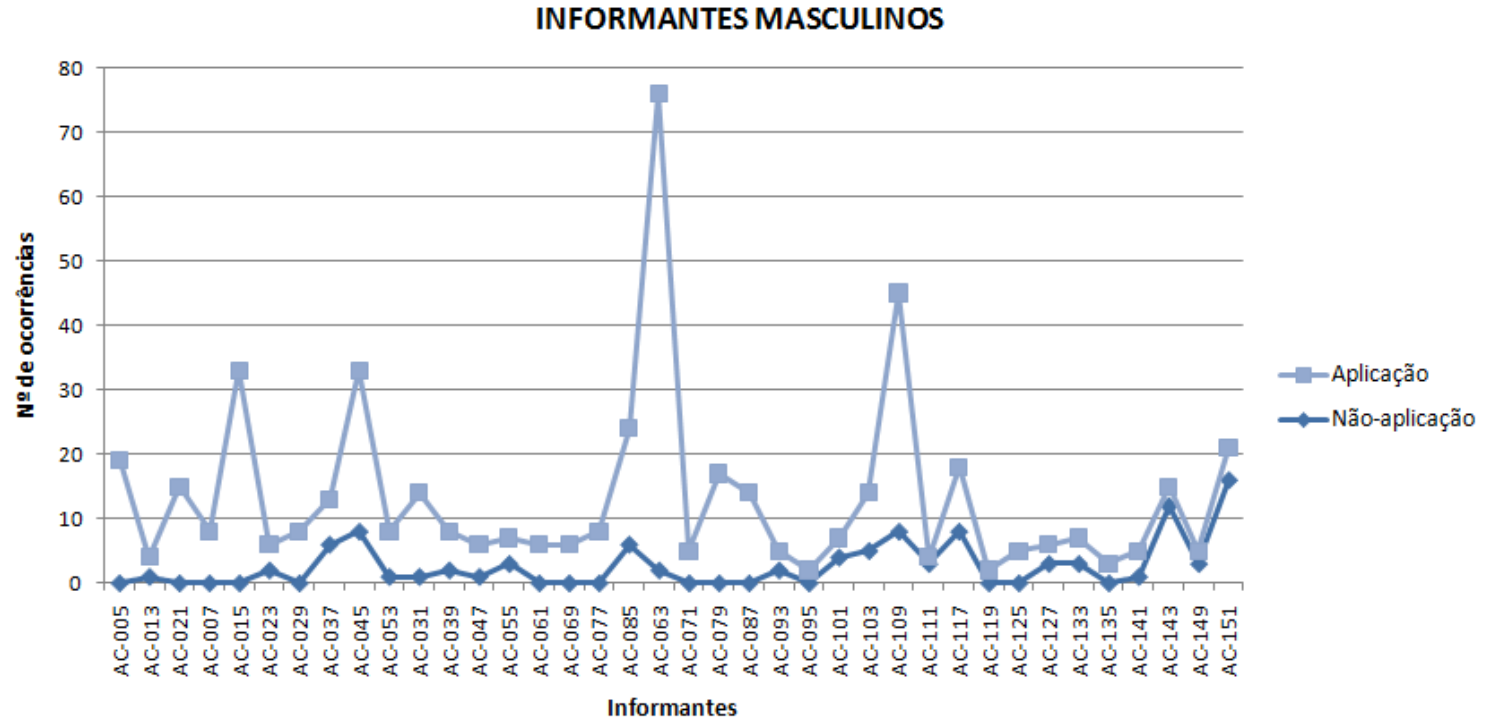

Gráfico 12. Número de ocorrências por informantes masculinos 
Tabela 34. Características sociais dos informantes de cada AC

\begin{tabular}{|c|c|c|c|c|c|}
\hline \multirow{2}{*}{\multicolumn{2}{|c|}{$\begin{array}{l}\text { Renda/Gênero } \\
\text { Faixa etária/Escolaridade }\end{array}$}} & \multicolumn{2}{|c|}{ De 6 a 10 SM } & \multicolumn{2}{|c|}{ Até $5 \mathrm{SM}$} \\
\hline & & Masc. & Fem. & Masc. & Fem. \\
\hline \multirow{4}{*}{7 a 15 anos } & $1^{\circ} \mathrm{C} . \mathrm{EF}$ & 005 & 006 & 007 & 008 \\
\hline & $2^{\circ} \mathrm{C} . \mathrm{E}$ & 013 & 014 & 015 & 016 \\
\hline & EM & 021 & 022 & 023 & 024 \\
\hline & $\mathrm{ES}$ & - & - & - & - \\
\hline \multirow[t]{4}{*}{16 a 25 anos } & $1^{\circ} \mathrm{C} . \mathrm{EF}$ & 029 & 030 & 031 & 032 \\
\hline & $2^{\circ} \mathrm{C} . \mathrm{E}$ & 037 & 038 & 039 & 040 \\
\hline & EM & 045 & 046 & 047 & 048 \\
\hline & ES & 053 & 054 & 055 & 056 \\
\hline \multirow[t]{4}{*}{26 a 35 anos } & $1^{\circ} \mathrm{C} . \mathrm{EF}$ & 061 & 062 & 063 & 064 \\
\hline & $2^{\circ} \mathrm{C} . \mathrm{E}$ & 069 & 070 & 071 & 072 \\
\hline & EM & 077 & 078 & 079 & 080 \\
\hline & ES & 085 & 086 & 087 & 088 \\
\hline \multirow[t]{4}{*}{36 a 55 anos } & $1^{\circ} \mathrm{C} . \mathrm{EF}$ & 093 & 094 & 095 & 096 \\
\hline & $2^{\circ} \mathrm{C} . \mathrm{E}$ & 101 & 102 & 103 & 104 \\
\hline & EM & 109 & 110 & 111 & 112 \\
\hline & $\mathrm{ES}$ & 117 & 118 & 119 & 120 \\
\hline \multirow[t]{4}{*}{+ de 55 anos } & $1^{\circ} \mathrm{C} . \mathrm{EF}$ & 125 & 126 & 127 & 128 \\
\hline & $2^{\circ} \mathrm{C} . \mathrm{E}$ & 133 & 134 & 135 & 136 \\
\hline & EM & 141 & 142 & 143 & 144 \\
\hline & ES & 149 & 150 & 151 & 152 \\
\hline
\end{tabular}

